UDK 929 Kasiodor

94(497.5)"05"(093)

Primljeno: 18. 9. 2015.

Prihvaćeno: 15. 11. 2015.

Izvorni znanstveni rad

\title{
Late Antique Dalmatia and Pannonia in Cassiodorus' Variae ${ }^{1}$
}

\author{
Hrvoje Gračanin \\ Philosophische Fakultät \\ Eberhard Karls Universität Tübingen \\ Wilhelmstraße 36 \\ 72074 Tübingen \\ Germany \\ Faculty of Humanities and Social Sciences \\ University of Zagreb \\ Ivana Lučića 3 \\ 10000 Zagreb \\ Croatia \\ E-mail: hrvoje.gracanin@gmail.com
}

As the title suggests, the present paper offers an analysis of selected letters from Cassiodorus' Variae, which are important for late antique history of Dalmatia and Pannonia. The study is intended to be twofold: on the one part, it examines the information that can be derived from the letters about both provinces' political, administrative, economic, social and ethnic picture in the time of Ostrogothic rule over the Eastern Adriatic and Middle Danube regions; on the other part, it explores literary and political contexts and underlying ideologies that are present in the selected letters.

Keywords: Cassiodorus' Variae, the Ostrogoths, Pannonia, Dalmatia, sixth century

\section{Introduction}

In this paper, I wish to provide a historiographical examination of Cassiodorus' Variae as a source for late antique history of Dalmatia and Pannonia, the provin-

\footnotetext{
1 I am particularly indebted to dear colleagues Mischa Meier, Christine Radtki and Sebastian SchmidtHofner for their invaluable insights and suggestions, as well as two anonymous peer reviewers who have saved me several omissions, which all improved the paper considerably. All translations in the paper are my own, even though Samuel J. B. Barnish's translation of selected letters from the Variae (Cassiodorus: Variae, Translated Texts for Historians 12, Liverpool: Liverpool University Press, 1992, repr. 2006) has also been consulted when possible.
} 
ces that were dominated by the Ostrogoths for about forty years, approximately from the mid-490s to the mid-530s. The historical information about Dalmatia and Pannonia that can be obtained from the selected letters are intended to be examined for what they have to offer with regard to the political, administrative, economic, social and ethnic situation in both provinces during the first three decades of the sixth century, which in large part coincides with the incipient Age of Justinian. Where appropriate to shed more light, these information will be set against the backdrop of what can be adduced from other available source material, both written and archaeological. On the second level, the examination will also include the exploration of narrative elements, intellectual and political contexts as well as ideological concepts and implications that constitute, define and emerge from the selected letters.

So far there have been a number of studies focusing on individual letters from Cassiodorus' Variae. As a model for the present study, however, three specific treatments are to be singled out, two of which deal with late antique Histria and the third one with the Adriatic Sea in the Variae. ${ }^{2}$ Even though the Ostrogothic period in Dalmatia and Pannonia has received a fair amount of scholarly attention, especially in recent time, there has never been an attempt at an exhaustive analysis of relevant Cassiodorus' letters. ${ }^{3}$ To be sure, there are also two recent

\footnotetext{
2 For Histria: Robert Matijašić, "Kasiodorova pisma kao izvor za poznavanje kasnoantičke povijesti Istre" [Cassiodorus' Letters as a Source for the Knowledge of Late Antique History of Istria], Zgodovinski časopis 42 (1988), no. 3: 363-371; Andrej Novak, L'Istria nella prima età bizantina (Rovigno; Fiume; Trieste: Centro di ricerche storiche; Unione italiana; Università popolare, 2007), 41-64. For the Adriatic Sea: Ludovico Gatto, "Il Mare Adriatico nelle 'Variae' di Cassiodoro", in: L'Adriatico dalla tarda antichità alletà carolingia. Atti del convegno di studio, Brescia 11-13 ottobre 2001, eds. Gian Pietro Brogiolo and Paolo Delogu (Firenze: All'Insegno del Giglio, 2005), 271-286.

3 The most instructive studies that are focused specifically on the Ostrogothic period in Dalmatia are Frank E. Wozniak, "The Continuity of Roman Traditions and the Ostrogothic Administration of Dalmatia in the Sixth Century", in: Papers for the V. Congress of Southeast European Studies (Belgrade, September 1984), eds. Kot K. Shangriladze and Erica W. Townsend (Columbus: Slavica Publishers, 1984), 374-382; Ante Uglešić, "Rimska provincija Dalmacija pod vlašću Istočnih Gota" [The Roman Province of Dalmatia under the Rule of the Ostrogoths], Radovi Filozofskog fakulteta u Zadru 30 (1990 - 1991), no. 17: 65-78, with mostly older Croatian scholarship on the topic, and Vladimir Posavec, "Prilog poznavanju ostrogotskog razdoblja u Dalmaciji" [A Contribution to the Knowledge of Ostrogothic Period in Dalmatia], Historijski zbornik 49 (1996): 1-15, with a survey of previous, mostly Croatian scholarship. For a latest survey of archaeological evidence relating to the Ostrogoths' presence in Dalmatia, see now Jana Škrgulja, "Larcheologia dell'Adriatico orientale tra il V ed il VII secolo: le evidenze archeologiche e i problemi della ricerca", in: AdriaAtlas et l'histoire de l'espace adriatique du VI ${ }^{e}$ s. a.C. au VIII s. p.C. Actes du colloque international de Rome (4-6 novembre 2013), eds. Yolande Marion and Francis Tassaux (Bordeaux: Ausonius Éditions, 2015), 101-107. The latest study focusing on the Ostrogothic period in Southern Pannonia is Hrvoje Gračanin and Jana Škrgulja, "The Ostrogoths in Late Antique Southern Pannonia”, Acta Archaeologica Carpathica 49 (2014) [2015]: 165-205, esp. 178-186 for Theoderic's Ostrogoths, with a detailed gazetteer of archaeological finds, and based on previous studies by Hrvoje Gračanin, "Goti i južna Panonija" [The Goths and Southern Pannonia], Scrinia Slavonica 6 (2006): 83126, esp. 104-113, and Južna Panonija u kasnoj antici i ranom srednjovjekovlju (od konca 4. do konca 11. stoljeća) [Southern Pannonia in Late Antiquity and the Early Middle Ages (from the late 4th to the late 11th centuries)] (Zagreb: Plejada, 2011), 90-102. Mate Suić, Prošlost Zadra, vol. I: Zadar u starom vijeku
} 
papers that draw concrete attention to Cassiodorus' letters as a source for the history of Ostrogothic rule over Dalmatia and Pannonia. ${ }^{4}$ Nevertheless, their focus in respect to various possible research aspects is rather limited and, for the most part, they merely adumbrate what is to be found of interest in Cassiodorus' letters regarding the late antique history of Dalmatia and Pannonia. Consequently, the present study aims at a more thorough, refined and deeper examination as to provide both a basis for a historical reconstruction and the evidence for an insight on how these provinces were viewed by the Ravenna government or, more precisely, how Cassiodorus intended them to be viewed by his contemporaries, i.e. his aimed audience and for what purpose. ${ }^{5}$ It is necessary to stress that the Variae are of prime importance as a source for late antique history of Dalmatia and Pannonia, since other major 6th-century written sources such as Procopius of Caesarea's History of the Wars, Marcellinus Comes' Chronicle with its continuation by an anonymous author, Jordanes' Getica and Romana or Menander Protector's History contain much less information on provinces themselves. ${ }^{6}$

[Zadar's Past: Zadar in Antiquity] (Zadar: Filozofski fakultet u Zadru, 1981), 319-323, has insightfully surveyed main features of the Ostrogothic rule over Dalmatia, whereas Stjepan Antoljak, "Zadar unter ostgotischer Herrschaft", Diadora 6 (1971): 207-220, is now generally outdated. The latest synthetic survey of the Ostrogothic period in Dalmatia and Pannonia, accompanied with an annotated bibliography, is offered by Robert Matijašić, Povijest hrvatskih zemalja u kasnoj antici od Dioklecijana do Justinijana [A History of Croatian Lands in Late Antiquity from Diocletian to Justinian] (Zagreb: Leykam international, 2012), 166-192.

4 Jana Škrgulja and Hrvoje Gračanin, "Barbaricum contra imperium: Prostor današnje jugozapadne Vojvodine između kasne antike i ranog srednjeg vijeka u svjetlu povijesnih i arheoloških svjedočanstava (5.-6. stoljeće)" [Barbaricum contra imperium: The Territory of Modern Southwestern Vojvodina between Late Antiquity and the Early Middle Ages in Light of Historical and Archaeological Evidence (5th-6th c.)], in: Vojvođanski prostor u kontekstu evropske istorije. Zbornik radova / The Region of Vojvodina in the Context of European History. Book of Proceedings 2, eds. Vladan Gavrilović and Svetozar Boškov (Novi Sad; Bačka Palanka: Filozofski fakultet u Novom Sadu, 2014), 14-16; Hrvoje Gračanin, "The history of the eastern Adriatic region from the $\mathrm{v}^{\text {th }}$ to the vii ${ }^{\text {th }}$ centuries AD: historical processes and historiographic problems", in: AdriaAtlas et l'histoire de l'espace adriatique du VIe s. a.C. au VIII s. p.C. Actes du colloque international de Rome (4-6 novembre 2013), eds. Yolande Marion and Francis Tassaux (Bordeaux: Ausonius Éditions, 2015), 77-78.

5 It is worth nothing that Jonathan J. Arnold, Theoderic and the Roman Imperial Restoration (Cambridge: Cambridge University Press, 2014), 47, rather deflates Cassiodorus' role in the Variae documents to "largely cosmetic and stylistic," which is in sharp contrast to the interpretation offered by Michael Shane Bjornlie, Politics and Tradition between Rome, Ravenna and Constantinople. A Study of Cassiodorus and the Variae 527-554 (Cambridge: Cambridge University Press, 2013), where Cassiodorus emerges as an active participant in esposuing different kinds of ideologies and political messages sensitive to contemporary debates about legitimacy and tradition (that Cassiodorus had been tuned to contemporary eastern discourse and debate about rule and imperial authority is also argued by Samuel J. B. Barnish, "Roman Responses to an Unstable World: Cassiodorus' Variae in Context", in: Viarium in Context (Vicenza: Centre for Medieval Studies Leonard Boyle, 2008), 11-16, where, however, is this seen as "perhaps unconscious", 13).

6 About these sources in the context of their relevance for late antique history of Dalmatia and Pannonia, cf. Škrgulja and Gračanin, "Barbaricum contra imperium", 11-18; Gračanin, "The history of the eastern Adriatic region", 73-75. 
It seems fitting first to briefly try to set the Variae collection in their context and offer some explanatory remarks with respect to their character. As for the author himself, his life and career need not be considered here. ${ }^{7}$ It suffices to say that, for the better part of his active years, he was involved in the highest echelons of power and influence in Ostrogothic Italy, at least on the strength of what is known from the letters themselves. ${ }^{8}$ The assemblage of official correspondence, which Cassiodorus styled the Variae, consists of 468 legal and administrative documents, among which there are formulae for appointment of high officials and narratives permeated with various abundant literary and scholarly digressions or imbued with outright panegyric sentiments. The letters are arranged in twelve books, to which a philosophical treatise De Anima had been originally added as the thirteenth book. ${ }^{9}$ The composition and language of the Variae letters, such as they stand, is rooted in the late antique tradition of formulaic and rhetorical shaping of official documents and, at the same time, departing from the usual chancery style, insofar as the official briefs had been intentionally given a form that establishes them within the frames of Roman epistolography and furnished with elaborate encyclopedic excursuses that testify to Cassiodorus' learned tastes and his attachment to rules and precepts of ancient rhetoric. ${ }^{10}$ It seems evident

\footnotetext{
7 On Cassiodorus life and career, see Joseph Jacobus van den Besselaar, Cassiodorus Senator en zijn Variae. De hoveling de diplomatieke oorkonden der Variae de rhetor (Nijmegen; Utrecht: Dekker \& van de Vegt n.v., 1945), 7-65; James J. O’Donnell, Cassiodorus (Berkeley; Los Angeles; London: University of California Press, 1979), 13-32; Stefan Krautschick, Cassiodor und die Politik seiner Zeit (Bonn: Dr. Rudolf Habelt, 1983), 1-20; Samuel J. B. Barnish, "Introduction”, in: Cassiodorus: Variae, translated with notes and introduction by Samuel J. B. Barnish, (Translated Texts for Historians 12) (Liverpool: Liverpool University Press, 1992 (repr. 2006), xxxix-liii; Andrea Giardina, Cassiodoro politico (Roma: L'Erma di Bretschneider), 2006, 22-25 (= Idem, "Cassiodoro politico e il progetto delle Variae", in: Teoderico il Grande e i Goti d'Italia. Atti del XIII Congresso internazionale di studi sull'Alto Medioevo, Milano 2-6 novembre 1992, vol. I (Spoleto: Centro italiano di studi sull'Alto Medioevo, 1993, 51-55).

8 It is rather a far-fetched, yet intriguing claim that Cassiodorus may have even fabricated his career track as to furnish himself with right credentials for the task he set on to accomplish with the Variae or that some letters may not even be genuine governmental documents at all (cf. Paul S. Barnwell, Emperor, Prefects \& Kings. The Roman West, 395-565 (London: Duckworth, 1992), 168-169). Van den Besselaar, Cassiodorus, 45, has already noted that Cassiodorus' contemporaries never mention him and the one that does, Jordanes, says nothing about his distinguished position at the Ravenna court. Yet, Van den Besselaar concludes that this "unanimous silence" may be understood as an indication that Cassiodorus indeed played a leading role in the contemporary politics. As for the authenticity of letters in their transmitted form, it is fair to assume that, in some instances, Cassiodorus extensively revised the content of letters (cf. Bjornlie, Politics and Tradition, 4-5, 332, who also claims that Cassiodorus even invented new letters, i.e. introduced forgeries).

9 Cf. Van den Besselaar, Cassiodorus, 6, 42-43; Andrew Gillett, "The Purpose of Cassiodorus'Variae", in: After Rome's Fall. Narrators and Sources of Early Medieval History. Essays presented to Walter Goffart, ed. Alexander Callander Murray (Toronto; Buffalo; London: University of Toronto Press, 1998), 40. For a discussion on the interrelation between the Variae and the De Anima, see Christina Kakridi, Cassiodors Variae. Literatur und Politik im ostgotischen Italien (München-Leipzig: K. G. Saur, 2005), 143-156; Bjornlie, Politics and Tradition, 293-299.

${ }^{10}$ On the composition and style of the Variae, see Barnish, "Introduction", xviii-xxiii; Bjornlie, Politics and Tradition, 206-215; with Idem, "The Rhetoric of Varietas and Epistolary Encyclopedism in the
} 
enough from Cassiodorus' prefaces, one at the beginning of the Variae, the other at the start of the eleventh book, that he intended his collection of artfully composed letters to have a wider audience and it may be assumed that he wanted it to circulate among members of the ruling elite in Italy, aristocrats, senior office holders and professional bureaucrats, but presumably among Latin-speaking senatorial class and high-ranking civil servants in Constantinople as well. ${ }^{11}$ In this respect, the Variae are probably best understood as a work serving many purposes. ${ }^{12}$ On the one hand, the collection was clearly conceived as a monument to Cassiodorus' skills and talents. ${ }^{13}$ In connection to this, the collection seems to have been also intended to provide practical models of rhetorical-didactical (and perhaps even ideological-political) instruction for chancellery officials. ${ }^{14} \mathrm{On}$ the other hand, as a recent study has suggested, Cassiodorus may have also wanted to offer an apologetic narrative designed to exemplify, justify and exalt his own and his fellow western palatine officials' execution of duty in the service of Ostrogot-

Variae of Cassiodorus", in: Shifting Genres in Late Antiquity, eds. Geoffrey Greatrex, Hugh Elton and Lucas McMahon (Farnham: Ashgate, 2015), 289-303; Gillett, “The Purpose”, 44-45; Kakridi, Cassiodors Variae, 16-142; O’Donnell, Cassiodorus, 85-96; Robin Macpherson, Rome in involution. Cassiodorus' Variae in their literary and historical setting (Poznań: Wydawnictvo naukowe uniwersytetu Im. Adama Mickiewicza w Poznaniu, 1989), 153-203. Detailed lexical and semantic studies include Åke J. Fridh, Études critiques et syntaxiques sur les Variae de Cassiodore (Göteborg: Wettergren \& Kerber, 1950); Idem, Terminologie et formules dans les Variae de Cassiodore. Études sur le développement du style administratif aux derniers siècles de l'antiquité (Stockholm: Almquist \& Wiksell, 1956); Idem, Contributions à la critique et à l'interprétation des Variae Cassiodore (Göteborg: Elanders Boktryckeri Aktiebolag, 1968); Valerio Neri, "Il lessico sociologico della tarda antichità: l'esempio delle 'Variae' di Cassiodoro", Studi storici 51 (2010), no. 1: 5-52; Paola Radici Colace, "Lessico monetario in Cassiodoro: simbologia della moneta e filosofia del linguaggio", in: Cassiodoro: dalla corte di Ravenna al Vivarium di Squillace. Atti del Convegno Internazionale di Studi, Squillace, 25-27 ottobre 1990, ed. Sandro Leanza (Soveria Mannelli: Rubbettino, 1993), 159-176; Bernhard Henry Skahill, The Syntax of the Variae of Cassiodorus (Washington, D.C.: The Catholic University of America Press, 1934); Mary Josephine Suelzer, The Clausulae in Cassiodorus. A Dissertation (Washington, D.C.: The Catholic University of America Press, 1944), 4, 17-36; Van den Besselaar, Cassiodorus Senator, 127-201; Gunhild Vidén, The Roman Chancery Tradition. Studies in the Language of Codex Theodosianus and Cassiodorus' Variae (Gothenburg: Acta Universitatis Gothoburgensis, 1984), 48, 50-75, 84-88, 91-92, 95-96, 98-100, 102, 104-106, 109, 112-113, 115-116, 136-153; Lorenzo Viscido, Lessico zoologico nelle "Variae" di Cassiodoro, 2nd ed. (Catanzaro: Grafiche Lucia, 2010); Odo John Zimmermann, The Late Latin Vocabulary of the Variae of Cassiodorus. With Special Advertence to the Technical Terminology of Administration (Hildesheim: Georg Olms Verlagsbuchhandlung, 1967). On the formulaic aspect of the Variae, see Bettina Pferschy, "Cassiodors Variae. Individuelle Ausgestaltung eines spätrömischen Urkundenformulars”, Archiv für Diplomatik 32 (1986): 1-127.

11 On the intended audience of the Variae, see Bjornlie, Politics and Tradition, 25, 189-196, 331; with Krautschick, Cassiodor, 116-117, and Barnish, "Introduction”, xxxi-xxxii. O’Donnell, Cassiodorus, 68, 69-70, is rather ambiguous on the matter.

12 Cf. Arnold, Theoderic and the Roman Imperial Restoration, 47 (note 16).

${ }^{13}$ Cf. Gillett, "The Purpose", 43-44, 49; with Idem, Envoys and Political Communication in the Late Antique West, 411-533 (Cambridge: Cambridge University Press, 2003), 176. See also Kakridi, Cassiodors Variae, 141-142. For Cassiodorus "literary vanity", see O’Donnell, Cassiodorus, 68, 70, 76. Contra Giardina, Cassiodoro politico, 26, 28 (= Idem, "Cassiodoro politico e il progetto delle Variae”, 56, 58).

${ }^{14}$ Cf. Kakridi, Cassiodors Variae, 131-133; with Gillett, “The Purpose”, 45, 50. 
hic kings in anticipation of the inevitable change of political regime in Italy. ${ }^{15}$ The obvious pro-Gothic propaganda that echoes throughout the Variae is perhaps better seen not as a mere "residue of the original letters," ${ }^{16}$ or a result of Cassiodorus' continuing striving to extol the Goths as their "presenter and interpreter," ${ }^{17}$ or a panegyrical monument to the Amal dynasty and a conciliatory effort directed towards the Roman senatorial aristocracy in favor of the Amal rule in Italy, ${ }^{18}$ but as Cassiodorus' oblique attempt to exonerate and praise the actions of the Romans who entered the service of their Ostrogothic masters and supported their policies since, by doing so, they were actually instrumental in preserving the Roman ways under basically the barbarians' dominance. When Cassiodorus does not shun his role in the Amal regime or his pro-Gothic sentiments, but instead clearly confesses them in the Variae, he skilfully uses this to convey an image of himself as a model of an able and devoted administrator who as firmly clings to the Roman traditions as to the orthodox Christian values, which by extension also applied to his fellow palatine officials, apparently all with an eye to make them acceptable to retain their acquired positions and status in the changing political climate of Italy during the Gothic war. ${ }^{19}$

\section{Contents and chronology of the letters}

The letters that relate to Dalmatian and Pannonian matters are scattered through the Variae and can be found in eight of their twelve books. A brief overview of the letters with their respective titles and pertinent contents is as follows: ${ }^{20}$

1) Osuin v. i. comiti Theodericus rex (1.40): instructing vir illustris Osuin to take care of adequate equipping and regular drilling of the soldiers stationed at Salona;

\footnotetext{
${ }^{15}$ Cf. Bjornlie, Politics and Tradition, 25, 310, 320-328; with Kakridi, Cassiodors Variae, 137-141. See also Barnish, "Roman Responses to an Unstable World", 15-16, for Cassiodorus' view on the place and role of an administrator vis-à-vis a variety of rule. Jean-Louis Jouanaud, "Pour qui Cassiodore a-t-il publié les Variae?", in: Teoderico il Grande e i Goti d'Italia. Atti del XIII Congresso internazionale di studi sull'Alto Medioevo, Milano 2-6 novembre 1992, vol. II (Spoleto: Centro italiano di studi sull'Alto Medioevo, 1993), 722, 741, has qualified the Variae as a governmental manual as well as a law code intended to legalize the situation in Italy under the Ostrogothic rule.

${ }^{16}$ Gillett, "The Purpose", 43.

17 Macpherson, Rome in involution, 113.

${ }^{18}$ Krautschick, Cassiodor, 186; O'Donnell, Cassiodorus, 70, 76, 100. See also Barnwell, Emperor, Prefects \& Kings, 169.

${ }^{19}$ Cf. Bjornlie, Politics and Tradition, 26-33; with Barnish, "Roman Responses to an Unstable World", 7-9, explaining the Variae in the context of political urgency.

${ }^{20}$ The titles are from the both standard editions of the Variae used for this study: Cassiodori Senatoris Variae, ed. Theodorus Mommsen, (Monumenta Germaniae Historica. Auctores Antiquissimi 12) (Berlin: Weidmann, 1894), 1-385; Cassiodori Variarum libri XII, in: Magni Aurelii Cassiodori Senatoris Opera I, ed. Åke J. Fridh, (Corpus Christianorum. Series Latina 96) (Turnhout: Brepols, 1973), 1-499.
} 
2) Colosseo v. i. comiti Theodericus rex (3.23): appointment of vir illustris Colosseus as governor of Pannonia Sirmiensis;

3) Universis barbaris et Romanis per Pannoniam constitutis Theodericus rex (3.24): notifying the inhabitants of Pannonia Sirmiensis about the appointment of vir illustris Colosseus as their governor;

4) Simeonio v. c. comiti Theodericus rex (3.25): entrusting vir clarissimus Simeonius with the task of collecting the tax siliquaticum and mining for iron ore in Dalmatia;

5) Osuin v. i. comiti Theodericus rex (3.26): instructing vir illustris Osuin to assist vir clarissimus Simeon in accomplishing his task;

6) Osuin v. i. comiti Theodericus rex (4.9): informing vir illustris Osuin that two orphaned minors, Maurentius and Paula respectively, are placed under the royal protection;

7) Senario v. i. comiti privatarum Theodericus rex (4.13): instructing vir illustris Senarius, in charge of the private royal estates, ${ }^{21}$ to provide necessary supplies for vir illustris Colosseus leaving for his duty as governor of Pannonia Sirmiensis;

8) Universis provincialibus et capillatis defensoribus et curialibus Siscia vel Savia consistentibus Theodericus rex (4.49): notifying the inhabitants, soldiers and town councilmen in Siscia and Savia about the appointment of Fridibadus to take charge of the province with a law-enforcing task;

9) Verani saoni Theodericus rex (5.10): instructing the saio Vera ${ }^{22}$ to organize the transport of the Gepids destined for Gaul on their way through Venetia and Liguria;

10) Gepidis ad Gallias destinatis Theodericus rex (5.11): notifying the Gepids destined for Gaul that they are to receive a payment of three solidi for the expenses incurred during their passage;

11) Severino v. i. Theodericus rex (5.14): entrusting vir illustris Severinus with fiscal and judicial superintending tasks in Savia;

12) Universis possessoribus in Savia provincia constitutis Theodericus rex (5.15): notifying the landowners in Savia about the appointment of vir illustris et magnificus Severinus to inquire into their complaints;

\footnotetext{
${ }^{21}$ Senarius is mentioned in 4.3 as being appointed as comes patrimonii, but the letters' titles consistently name his office as comes privatarum $(4.3 ; 4.7 ; 4.11 ; 4.13)$, which would equally refer to the office of comes rerum privatarum. Roland Delmaire, Largesses sacrées et res privata. Laerarium impérial et son administration du IV au VI siècle (Rome: École française de Rome, 1989), 692, has interpreted this discrepancy as an error by a copyist.

22 On the name, see John Robert Martindale, The Prosopography of the Later Roman Empire, vol. II: A.D. 305-527 (Cambridge: Cambridge University Press, 1980), 1154-1155; Patrick Amory, People and Identity in Ostrogothic Italy 489-554 (Cambridge: Cambridge University Press, 2003), 433.
} 
13) Epiphanio v. s. consulari provinciae Dalmatiae Theodericus rex (5.24): instructing vir spectabilis Epiphanius, the consularis of Dalmatia, to inquire into a specific fiscal matter about an intestate's property that should be claimed for the state;

14) Formula de comite insulae Curitanae et Celsinae (7.16): a formula for the appointment of a comes in charge of the islands of Krk and Cres;

15) Formula principis Dalmatiarum (7.24): a formula for the appointment of an official in charge of overseeing the judiciary in Dalmatia;

16) Diversis Romanis per Italiam et Dalmatias constitutis Athalaricus rex (8.4): a proclamation to the Romans in Italy and Dalmatia regarding King Athalaric's accession;

17) Senatui urbis Romae Athalaricus rex (8.10): an address to the Roman Senate regarding the appointment of vir praecelsus and King Athalaric's inlaw Tuluin as patricius praesentalis, where it is mentioned that Tuluin participated in the expeditio Sirmiensis and fought the Huns, i.e. the Bulgars (8.10.4);

18) Aratori v. i. Athalaricus rex (8.12): appointment of vir illustris and comes domesticorum (vacans) Arator to a comitiva, where it is mentioned that Arator was on a previous occasion directed from Dalmatia to King Theoderic to speak on behalf of the provincials about their needs (8.12.3);

19) Cypriano v. i. patricio Athalaricus rex (8.21): elevating vir illustris Cyprianus, also called vir magnificus (8.22.1), to the rank of patricius, where it is mentioned that he participated, under Theoderic, in the campaign on the Danube ${ }^{23}$ and fought the Bulgars (8.21.3);

20) Osuin v. i. comiti Athalaricus rex (9.8): appointment of vir illustris Osuin again as governor of Dalmatia and Savia;

21) Universis Gothis sive Romanis Athalaricus rex (9.9): notifying the Gothic and Roman inhabitants in the provinces about the appointment of vir illustris Osuin as governor of Dalmatia, the simultaneous sending of vir illustris Severinus to the provinces, and the remitting of the surtax augmentum owed for the fourth indiction (1 September 525 - 31 August 526) in honor of commencement of King Athalaric's reign;

22) Senatui urbis Romae Senator PPO (11.1): an address to the Roman Senat on occasion of Cassiodorus' promotion to the post of praefectus praetorio Italiae, where it is remarked about the cession of Illyricum and division of provinces by the Western Roman Empress Galla Placidia in favor of the Eastern Empire (11.1.9) as well as alluded to a clash between the Goths and the Eastern Empire in the Danube region (11.1.10-11).

\footnotetext{
${ }^{23}$ Since the letter mentions the gentilis Danubius ("the barbarian Danube"), the campaign against the Gepids is likely to be meant (cf. Martindale, The Prosopography, 332; Amory, People and Identity, 73).
} 
To these, two more letters may be added that actually refer to Histria, but also contain information that could be brought into connection with Dalmatia:

1) Provincialibus Histriae Senator PPO (12.22): a notification to the inhabitants of Histria about requisitions in kind that are to be carried out by an official named Laurentius, containing a rather flattering description of the province, certain parts of which seem to relate to the Dalmatian seashore (the Kvarner Bay region), such as the mention of "a most beautiful array of islands appended to the coast of Histria, which, arranged with a delightful usefulness, both shields ships from peril and enriches the farmers by great fertility" (12.22.5);

2) Tribunis maritimorum Senator PPO (12.24): instructing the tribunes of the coasts in Venetia to provide naval transport of the necessary supplies requisitioned in Histria, where it is said that these tribunes often traverse vast sea distances (12.24.1), which probably also alludes to their regular contacts with the Dalmatian coast, no doubt out of commercial reasons, and perhaps primarily in search of salt that is singled out by Cassiodorus as their most valuable commodity (12.24.6).

The letters are dated to years spanning over three decades. A comparative chronological table based on dating by Theodor Mommsen, who is copied by Åke Johansson Fridh, Lellia Ruggini, Stefan Krautschick and Jan Prostko-Prostynski is as follows:

\begin{tabular}{|c|c|c|c|c|}
\hline Letter & Mommsen/Fridh ${ }^{24}$ & Ruggini $^{25}$ & Krautschick $^{26}$ & $\begin{array}{c}\text { Prostko- } \\
\text { Prostynski }^{27}\end{array}$ \\
\hline 1.40 & $507 / 511$ & & 508 & \\
\hline 3.23 & $507 / 511$ & & 510 & \\
\hline 3.24 & $507 / 511$ & & 510 & \\
\hline 3.25 & $510 / 511$ & $510 / 511$ & 510 & \\
\hline 3.26 & $510 / 511$ & & 510 & \\
\hline 4.9 & $507 / 511$ & & 511 & \\
\hline 4.13 & $509 / 510$ & & $511 ?$ & \\
\hline 4.49 & $507 / 511$ & & 511 & \\
\hline 5.10 & $523 / 526$ & $523 / 524$ & 523 & \\
\hline 5.11 & $525 / 526$ & $523 / 524$ & 523 & \\
\hline
\end{tabular}

\footnotetext{
${ }^{24}$ Cassiodori Senatoris Variae, ed. Mommsen, 36, 92, 97, 120, 136, 149, 150, 151, 157, 234, 239, 242, 274, 275, 327, 378, 379; Cassiodori Variarum libri XII, ed. Fridh, 45, 113, 114, 115, 116 151, 175, 190, 192, 194, 202, 303, 309, 313, 355, 356, 422, 488, 491.

${ }^{25}$ Lellia Ruggini, Economia e società nell', Italia Annonaria“. Rapporti fra agricoltura e commercio dal IV al VI secolo d. C., Milano: Dott. A. Giuffrè Editore, 1961, 555, 557 (2nd ed., Bari: Edipuglia, 1995).

${ }^{26}$ Krautschick, Cassiodor, 66, 75 (3.25; 3.26); 67-68 (4.13); 69, 75 (5.10; 5.11); 73 (1.40); 75 (3.23; 3.24$) ; 76$ (4.9); 77 (5.14; 5.15; 5.24); 76 (4.13; 4.49); 87, 102 (8.12); 88, 102 (8.21); 89, 103 (9.8; 9.9); 96, 105 (11.1); 100$101,106(12.22 ; 12.24) ; 102(8.4 ; 8.10)$.

27 Jan Prostko-Prostynski, „Zur Chronologie der Bücher VI und VII der 'Variae' von Cassiodor“, Historia 53.4 (2004), 508.
} 


\begin{tabular}{|c|c|c|c|c|}
\hline 5.14 & $525 / 526$ & & $526 ?$ & \\
\hline 5.15 & $525 / 526$ & & $526 ?$ & \\
\hline 5.24 & $525 / 526$ & & $523 / 526$ & \\
\hline 7.16 & & & & $531-533 / 537 ?$ \\
\hline 7.24 & & & & 531-533/537? \\
\hline 8.4 & after 30 Aug 526 & & $\begin{array}{c}\text { very shortly after } \\
30 \text { Aug } 526\end{array}$ & \\
\hline 8.10 & the late 526 & & $\begin{array}{c}\text { very shortly after } \\
30 \text { Aug } 526\end{array}$ & \\
\hline 8.12 & the late 526 & & $\begin{array}{c}\text { very shortly after } \\
30 \text { Aug } 526\end{array}$ & \\
\hline 8.21 & around 527 & & 527 & \\
\hline 9.8 & 526 & & $\begin{array}{c}\text { soon after } 30 \text { Aug } \\
526 \\
\end{array}$ & \\
\hline 9.9 & $526 / 527$ & & $\begin{array}{c}\text { soon after } 30 \text { Aug } \\
526\end{array}$ & \\
\hline 11.1 & 533 & & $\begin{array}{c}\text { shortly after } 1 \\
\text { Sept } 533\end{array}$ & \\
\hline 12.22 & $537 / 538$ & autumn 537 & Sept/Dec 537 & \\
\hline 12.24 & $537 / 538$ & autumn 537 & Sept/Dec 537 & \\
\hline
\end{tabular}

It strikes as odd that, according to Mommsen, the letters 5.10 and 5.11, 5.14 and 5.15, and 3.23, 3.24 and 4.13 should have different respective dates, even though the first two letters are both concerned with the passage of the Gepids through Venetia and Liguria, the other two both relate to the sending of vir illustris Severinus to Savia, while the last three all refer to the sending of comes Colosseus as governer of Pannonia Sirmiensis. Hence these three groups of letters must have been issued at the same respective times, and the discrepancy is probably due to Mommsen's inadvertent oversight. The letters 5.10 and 5.11 have been dated by Ruggini and Krautschick to 523/524 and 523 respectively, since the relocation of the Gepids was clearly connected to the Ostrogothic attempt to secure their positions in Gaul against the Burgundians. ${ }^{28}$ It is likely that the Gepids were deployed after the completion of immediate military operation, since they do not seem to have been a part of regular forces, even though they are referred to as exercitus (5.10.1). ${ }^{29}$ The custodiae causa (5.10.2), which is cited in the letter as the reason

\footnotetext{
${ }^{28}$ Ruggini, Economia e società, 272 (note 178); Krautschick, Cassiodor, 69, with note 3. Cf. Herwig Wolfram, Die Goten. Von den Anfängen bis zur Mitte des sechsten Jahrhunderts. Entwurf einer historischen Ethnographie, 3rd ed. (München: Verlag C.H. Beck, 1990), 322.

${ }^{29}$ The multitudo Gepidarum seems to have included both Gepidic men and their families (for the discussion, cf. infra the section Provincial ethnic picture), and hence it is not very probable that they would be used for the military operation itself. The operation in Gaul was commanded by Tuluin who is said to have been sent back "to defend Gauls while the Frank and the Burgund were clashing, lest the enemy hand should take that which our army had claimed with great toils" and "acquired for the Roman state, with no exertion, Province while others were fighting, and our interest was peacefully brought about,
} 
for the relocation of the Gepids, may only relate to their being intended as a contingent for securing the newly acquired territories. ${ }^{30}$ Therefore their move need not be necessarily dated to 523 (but it must have not happened much later, perhaps in 524). ${ }^{31}$ Even if the letter 5.13 that is addressed to the otherwise unknown Eutropius and Agroecius, who are mentioned without titles and offices but may have been clerks of the praetorian praefecture of Italy, and concerned with the supply of troops, belongs to this time, which is likely, there is no need to assume that it relates to the march of the Gepids as it has been suggested. ${ }^{32}$ The matter of a regular supply of troops and seeing to it that the provincials do not suffer damage from the soldiers was a continuous concern for the Ravenna government regardless of whether there was an ongoing campaign or not, which is testified by several other letters from the Variae $(2.5 ; 2.8 ; 3.42 ; 4.13 .2 ; 4.36 ; 5.23 ; 9.13 ; 10.18 .2$; $\left.12.5 .6 ; 12.18 .6^{33}\right)$. Furthermore, since the saio Vera was already charged with a specific task of overseeing the march of the Gepids (5.10), Eutropius and Agroecius were probably assigned to provide supplies for the troops in general and had no dealings with the Gepids.

The letters 3.23, 3.24 and 4.13 have too been differently dated by Krautschick, the first two to 510 and the third tentatively to 511 . However, it is clear from the content of the third letter that it relates to the providing of necessary supplies for the comes Colosseus as he was leaving for his duty as governor, which means that the third letter should also be dated as the first two, presumably to 510. The letter 3.25 apparently contains information that could provide a more precise dating for both this letter and the letter 3.26. It instructs the vir clarissimus Simeonius to collect arrears of the siliquaticum for the first (1 September 507 - 31 August 508), second (1 September 508 - 31 August 509) and third (1 September $509-31$ August 510) indictions. ${ }^{34}$ Accordingly, Mommsen dated the letter to the fourth indiction, i.e. to the period from 1 September 510 to 31 August 511. However, the letter seems to belong to the year $510 .{ }^{35}$ It is fair to assume that the central

since we did not suffer the peril of warlike conflict" (8.10.10: Mittitur igitur, Franco et Burgundione certantibus, rursus ad Gallias tuendas, ne quid adversa manus praesumeret, quod noster exercitus impensis laboribus vindicasset. Adquisivit rei publicae Romanae aliis contendentibus absque ulla fatigatione Provinciam et factum est quietum commodum nostrum, ubi non habuimus bellica contentione periculum).

${ }^{30}$ Cf. Gračanin and Škrgulja, “The Ostrogoths”, 185.

31 Wolfram, Die Goten, 322, sets 523 as the earliest possible date. Amory, People and Identity, 94, seems to think that this happened following the Ostrogothic intervention in Gaul in 508.

32 Ruggini, Economia e società, 273 (note 178).

33 The last two examples are from the time when the war with the Eastern Romans had already begun.

${ }^{34}$ Frank E. Wozniak, "East Rome, Ravenna and Western Illyricum: 454-536", Historia 30 (1981), no. 3: 375, errs when he cites the years 506 to 509 for the first, second and third indictions. The same oversight has been made by Thomas Hodgkin, The letters of Cassiodorus, being a condensed translation of the Variae epistolae of Magnus Aurelius Cassiodorus Senator, London: Henry Frowde, 1886, 210.

${ }_{35}$ Cf. Krautschick, Cassiodor, 66. John J. Wilkes, Dalmatia, London: Routledge \& Kegan Paul, 1969, 424, has erroneously dated Simeonius' mission to 508 . 
government was eager to exact the due arrears for as many as three consecutive fiscal years following the termination of the third indiction. Furthermore, Simeonius was entrusted with searching for exploitable iron mines in interior Dalmatia, a task not easily accomplished in inconvenient climate conditions of autumn and winter months, which are characteristic for the region during these seasons. Considering all this, the letters 3.25 and 3.26 are perhaps likely to date from September or October 510.

Four letters recall the events from the past, both near and remote. The letters 8.10 and 8.21 that recount Tuluin's and Cyprianus' respective career paths on occasion of their appointments - Tuluin to the post of patricius praesentalis probably in early September 526, and Cyprianus to the rank of patricius in 527 - mention their participation in the conquest of Pannonia Sirmiensis and their fight against the Bulgars, which happened two decades before, in 504 and 505 respectively. ${ }^{36}$ The letter 8.12 that relates to the appointment, probably also in September 526, of vir illustris Arator to a comitiva touches upon his eloquent appeal on behalf of Dalmatian provincials before King Theoderic. Arator's embassy must have happened in 526 at the latest. Since this is the only concrete example of Arator's oratorical skills singled out in the letter, the embassy presumably did not occur in a too distant past from when the letter was composed, probably after he was honored with the title of comes domesticorum (vacans), which he apparently had already held in 526 and must have received from King Theoderic.

Finally, the letter 11.1, dating presumably from September 533, refers to the events on the occasion of betrothal and marriage of Valentinian III and Licinia Eudoxia in 424 and 437 respectively, ${ }^{37}$ as well as relates to the attack of the Gepids on Pannonia Sirmiensis and the subsequent Ostrogothic counterstrike that violated the Eastern Roman territory, both of which happened in $528 .{ }^{38}$ The two letters that contain respective formulae for appointment of comes insulae Curitanae et Celsinae (7.16) and princeps Dalmatiarum (7.24) are only tentatively dated to the period between 531-533 and 537. The logic behind such a conjecture is that Cassiodorus composed his formulae consulatus, patriciatus and praefecturae urbanae between these two dates, since he seems to have had a full knowledge of Justinian's law on patricians (Cod. Just. 12.3.5) issued between 531 and 533, and no knowledge of Justinian's regulation on senators (Nov. Just. 62.2) from 537, and that this dating can be applied to the entire sixth and seventh books. ${ }^{39}$ Moreover, the date span for the composition of the books can be further narrowed if one accepts the interpretation that Cassiodorus actually wrote the formulae while holding the office of praefectus praetorio Italiae (from 1 September 533), as he

\footnotetext{
${ }^{36}$ For the date, see Gračanin and Škrgulja, “The Ostrogoths”, 182.

${ }^{37}$ Cf. Hrvoje Gračanin, “The Huns and South Pannonia”, Byzantinoslavica 64 (2006): 54.

${ }^{38}$ Gračanin and Škrgulja, "The Ostrogoths”, 185.

${ }^{39}$ Prostko-Prostynski, "Zur Chronologie”, 505-508.
} 
himself seems to indicate in his preface to the Variae. ${ }^{40}$ However, it has also to be borne in mind that many formulae must have originated from previous samples written by Cassiodorus that were already in circulation and used for appointment of officials, but may not have been so elaborate, or were composed by other administrators apart from Cassiodorus, which is to say that the date of the composition of formulae does not chronologically correspond to actual introduction of certain offices.

\section{Provinces and their administration}

The Variae clearly show that the Ostrogoths followed in the main the late Roman provincial organization in Dalmatia and Pannonia. The letters mention Sirmiensis Pannonia (3.23.2: provincia; 4.13.1), Pannonia (3.24 titulum), Savia (4.49 titulum; 5.14.1; 5.14.3: provincia; 5.14.5: provincia), Savia provincia (5.15 titulum), provincia Dalmatica (3.25.1), provincia Dalmatia (3.26; 5.24: titulum), provinciae Dalmatiarum atque Saviae (9.8.1; 9.8.2: provinciae), provinciae Dalmatiae (9.9.1), Dalmatiae (7.24 titulum; 7.24.2: provinciae $^{41}$; 7.24.3: provincia). There were however significant changes, the most conspicuous of which was merging of Savia and Dalmatia under the authority of a single comes. It is unknown when this change occurred, but it may have happened shortly after the Ostrogothic conquest of Pannonia Sirmiensis in 504 and definitely before 526 when the Variae mention Osuin as comes of the united provinces (9.8.1). ${ }^{42}$ Since the letter says that Osuin is iterum assigned to the post, this change must have been effected under Theoderic and not by Athalaric's government. To be sure, Savia and Dalmatia are both called provinces in their own right, and even when their joining is explicitly indicated, the plural provinces is still used, which would imply that they retained, to some extent, their own independent jurisdictions. This is possibly further substantiated by the fact that officials were appointed with an authority that was confined solely to Savia $(4.49,5.14)$, and that there were civil officials whose authority extended only to Dalmatia $(5.24,7.24)$. The rationale behind the decision to administratively unite these two provinces may have been that Savia ceased to be a more exposed strategic frontier region after the Ostrogoths had acquired Pannonia Sirmiensis and therefore there was no need for Savia to retain an individual comes. ${ }^{43}$

\footnotetext{
${ }^{40}$ Prostko-Prostynski, "Zur Chronologie”, 505.

${ }^{41}$ Since provinciarum is paired with the preceding comes, the plural is very likely to refer to the provinciae Dalmatiarum atque Saviae.

${ }^{42}$ Wozniak, "East Rome", 373, seems to believe that the entire administrative organization of Pannonia Secunda, Savia and interior Dalmatia was carried out between 507 and 510.

${ }^{43}$ Cf. Wilhelm Ensslin, Theoderich der Grosse, 2nd ed., München: Verlag F. Bruckmann, 1959, 193. Thomas S. Burns, A History of the Ostrogoths (Bloomington: Indiana University Press, 1984), 174-175, believes that Savia had its own comes until the revival of Gepidic power around Sirmium, whereas Wolfram, Die Goten, 320, claims that the uniting of Dalmatia and Savia occured before 504. See also Hrvoje Gračanin, "Crkveni ustroj u kasnoantičkoj južnoj Panoniji" [Ecclesiastical Organization in Southern
} 
Another administrative change was the creation of a separate comitiva for the islands of Krk and Cres in Kvarner Bay (7.16). ${ }^{44}$ The precise date is not known, and the matter is of some importance, since it has been proposed that this change was in some way connected to the outbreak of the war between the Eastern Romans and the Ostrogoths in $535 .{ }^{45}$ The formula for appointment of the comes contains the phrase antiquae consuetudinis morem secuti, "following the custom of ancient practice" (7.16.1), but this is likely to mean nothing more than that the appointment procedure had its antecedents in Roman times, even though the office iself was an Ostrogothic innovation. ${ }^{46}$ Consequently, the phrase cannot be used as an indication that the comitiva existed for some time before the 530s. However, based on what the letter says, the decision to create the comitiva seems not to have been inspired by pressing military needs, but by a wish to provide better legal security for islanders who are perceived as isolated from their fellow provincials living on the mainland. ${ }^{47}$ This contradicts the opinion that the comiti-

Pannonia in Late Antiquity], Croatica Christiana periodica 38 (2014), no. $73: 7$ (= in Znakovi i riječi 4 - Signa et litterae IV. Zbornik projekta "Mythos - cultus - imagines deorum". De ritv ad religionem Od obreda do vjere, eds. Bruna Kuntić-Makvić and Inga Vilogorac Brčić (Zagreb: FF press, 2013) 159, where it is suggested that the joining of two provinces may have been additionally prompted by their ecclesiastical administrative ties. To be sure, this argument could also be reversed, that is to say, the close ecclesiastical association between Dalmatia and Savia, which are clear from the church councils held in Salona in 530 and 533, may have been the result of merging of Savia and Dalmatia under the authority of a single provincial comes.

44 This identification has had a long tradition in Croatian scholarship. Cf. for example, Mate Suić, "Granice Liburnije kroz stoljeća" [Borders of Liburnia Through Centuries], Radovi Instituta JAZU u Zadru 2 (1955): 286, with note 78, p. 293; Julijan Medini, “Provincia Liburnia”, Diadora 9 (1980): 413 (note 151); Tin Turković and Ivan Basić, "Nuove conoscenze sulla Liburnia Tarsaticensis nel contesto dello studio delle fonti geografiche", Atti del Centro di Ricerce Storiche di Rovigno 41 (2011) [2012]: 88. Interestingly enough, it is overlooked by Robert Matijašić, "Le isole di Cherso e Lussino in età romana", Atti del Centro di Ricerce Storiche di Rovigno 20 (1989 - 1990): 255-273. This identification has even been accepted by some Italian scholars, cf. Vito A. Sirago, "I Goti nelle Variae di Cassiodoro", in: Atti della Settimana di studi su Flavio Magno Aurelio Cassiodoro (Cosenza-Squillace, 19-24 settembre 1983), ed. Sandro Leanza (Soveria Mannelli: Rubbettino, 1986), 182, with note 16, p. 199, and, most recently, Giovanni A. Cecconi, „Comment to 7.16“, in Flavio Magno Aurelio Cassiodoro Senatore, Varie, vol. III: Libri VI-VII, eds. Andrea Giardina, Giovanni Alberto Cecconi, and Ignazio Tantillo, Roma: „L'Erma“ di Bretschneider, 2015, 229-230. However, Wilkes, Dalmatia, 427, and Volker Bierbrauer, Die ostgotischen Grab-und Schatzfunde in Italien (Spoleto: Centro Italiano di Studi sull'Alto Medioevo, 1976), 25, have identified Curitana and Celsina as the island of Krk and its city. Similarly, Gatto, "Il Mare Adriatico", 277, speaks only of the island of Krk (Veglia). Even though the title of the letter mentions the word insula in singular, the text clearly has plural, insulis (7.16.1), for both Curitana and Celsina, which certainly indicates that no city could be meant under Celsina.

${ }^{45}$ Medini, "Provincia Liburnia", 413-414. For a differing view, see Tin Turković and Ivan Basić, "Kasnoantička i ranosrednjovjekovna Tarsatička Liburnija (Liburnia Tarsaticensis) u svjetlu geografskih izvora" [Late Antique and the Early Medieval Liburnia Tarsaticensis in Light of Geographical Sources], Starohrvatska prosvjeta 3rd ser. 40 (2013): 47.

${ }^{46}$ Cassiodorus uses similar phrases elsewhere: iuxta consuetudinem veterem (4.13.1); prisca consuetudo (7.21.1); secundum priscam consuetudinem (7.25.2); priscae consuetudinis ratio (7.30.1).

47 "For it is just that he who, with a commendable purpose, order those who are separated from association with the rest of humanity comes to their residences so that there is no need to ignore communal acts of injustice that are placed far off. Therefore let you, the aforementioned, have one who is obliged 
va insulae Curitanae et Celsinae was a naval military district designed as a forward defense area of Italy, and whose commander supposedly had a strong fleet at his disposal. ${ }^{48}$ Building upon this, it has also been inferred that a tract of nearby mainland was included in the district or even another island, that of Lošinj in the proximity of Cres. ${ }^{49}$ Yet, these speculations have no confirmation in sources. Even though the very existence of the comitiva testifies to the Ostrogoths' regarding the Kvarner Bay area, particulary the islands of Krk and Cres, as undoubtedly important, surely for strategic reasons, there is no real evidence that this was a military district. The fact that the comes insulae Curitanae et Celsinae is called both prior and iudex (7.16.1) indicates that he is likely to have been a civil administrator and not a military comes Gothorum. ${ }^{50}$ The placing of the letter among the formulae that deal with civil offices may be perhaps taken as equally telling. ${ }^{51}$ Finally, it is difficult to imagine that, in the war time, the Ravenna government would introduce a new office that was apparently civil in its nature. Hence it may be assumed that the

to both listen and decide the cases that ensue between you" (7.16.2: Iustum est enim ut qui a reliquorum hominum sunt conversatione divisi, ad habitationes eorum vadat qui eos probabili ratione componat, ne quaedam sit necessitas iniustitiae communes actus longe positos ignorasse. Habetis igitur, supra dicti, qui inter vos emergentes causas et audire debeat et finire). The view that the comes insulae Curitanae et Celsinae was a civil administrator was first entertained by Lujo Margetić, "Noviji pogledi na stariju povijest Vinodola, Krka i Senja" [Newer Views on Older History of Vinodol, Krk and Senj], Zbornik Pravnog fakulteta u Rijeci 9 (1988): 10.

${ }^{48}$ Medini, "Provincia Liburnia", 413-414, 425, 427, 429. Cf. also Turković and Basić, "Nuove conoscenze", 68, 89; Idem, "Kasnoantička i ranosrednjovjekovna", 47, 50, 73, who only develop on older ideas by Mate Suić and Jaroslav Šašel. Contra Margetić, "Noviji pogledi", 10-11.

${ }^{49}$ Suić, "Granice Liburnije”, 286; Medini, "Provincia Liburnia”, 413-414. Cf. also Turković and Basić, "Nuove conoscenze", 88; Idem, "Kasnoantička i ranosrednjovjekovna", 71.

${ }^{50}$ Cf. Ludwig Schmidt, "Die comites Gothorum. Ein Kapitel zur ostgotischen Verfassungsgeschichte", Mitteilungen des Österreichischen Instituts für Geschichtsforschung 40 (1925): 132; with Zimmermann, The Late Latin Vocabulary, 243. Similarly Kayoko Tabata, "I comites Gothorum e l'amministrazione municipale in epoca Ostrogota", in: 'Humana Sapit'. Études d'Antiquité tardive offertes à Lellia Cracco Ruggini, eds. Jean-Michel Carrié and Rita Lizzi Testi (Turnhout: Brepols, 2002), 74. See also Burns, A History, 176-177 (albeit he mentions as a possibility that a prior also had some military function); Wolfram, Die Goten, 320; Amory, People and Identity, 408 (s.v. Quidila 2); Gideon Maier, Amtsträger und Herrscher in der Romania Gothica. Vergleichende Untersuchungen zu den Institutionen der ostgermanischen Völkerwanderungsreiche (Stuttgart: Franz Steiner Verlag, 2005), 216-218, for the Roman comites civitatis that held solely a civil judicial authority and are styled in the Variae as iudices, and with which this comes insulae may perhaps be brought into connection. Contra Ernst Stein, "Untersuchungen zur spätrömischen Verwaltungsgeschichte", in: Idem, Opera minora selecta (Amsterdam: Adolf M. Hakkert, 1968), 180; Frank M. Ausbüttel, Die Verwaltung der Städte und Provinzen im spätantiken Italien (Frankfurt am Main et al.: Peter Lang, 1988), 206, with note 11, p. 312. It should be noted that the character of the office of a prior is not entirely clear and it should therefore be determined from case to case. That the comes insulae Curitanae et Celsinae had Gothic troops under his command, which would make him a comes Gothorum, is maintained by Burns, A History, 176, who lists the islands of Curicta and Celsina among cities where the Goths established their garrisons, and Sirago, "I Goti nelle Variae", 182, who ascribes military defensive, i.e. police duties to this comes.

${ }^{51}$ The preceding formula is concerned with the appointment by the city prefect of the architect of Rome (7.15: Formula ad praefectum urbis de architecto faciendo in urbe Roma), and the following formula relates to the appointment of the superintendant of limework (7.17: Formula de praeposito calcis). 
comitiva was established before the 530s, probably under Theoderic, considering that he is also credited with the other administrative change in the region, the uniting of the provinces of Dalmatia and Savia, and is shown as often involved in provincial matters. The fact that the relevant formula presumably dates from 533 to 537 does not contradict the suggested view, since the actual composition of formulae and the pertaining offices do not correlate chronologically.

The name forms of provinces also merit attention. The late Roman province of Pannonia Secunda was now known as Pannonia Sirmiensis (3.23.2; 4.13.1), which testifies to the importance with which the Ostrogoths regarded Sirmium. Since the letter 3.24 calls the province simply Pannonia, this seems to indicate that it could not be mistaken for the province of Savia, which is actually never mentioned in conjunction with Pannonia, but exclusively as Savia. It may well be that the identification of the term Pannonia with Pannonia Sirmiensis was the result of joining of Savia with Dalmatia. ${ }^{52}$ However, it is also possible that Savia was never viewed by the Ostrogoths as a part of the proper Pannonia. The Anonymous Cosmographer of Ravenna, who seems to have composed his work in the early ninth century, but based it upon, among other sources, the works by Gothic geographers of the sixth century, knows not of Savia (nor Suavia for that matter), but instead mentions Valeria, que et Media Provincia..$^{53}$ Citing a Gothic philosopher Marcomir as his source, the Anonymous describes this patria as lying between the Upper and Lower Pannonia and bordering on the Sava, and enumerates as its civitates places that actually belonged to the Pannonian provinces of Savia, Secunda and Valeria, among others, Siscia, the provincial capital of Savia ${ }^{54}$ Furthermore, the majority of the manuscripts of the Variae consistently use the form Suavia or Suevia for Savia, which both Mommsen and Fridh have emended, in their respective editions, to the original name of the late Roman province..$^{55}$ Whereas Savia derives its name from the river Sava, the form Suavia or Suevia seems to have originated from the Suevi/Suebi/Suavi, meaning a land of the Suevi. Jordanes also speaks of Suavia in the vicinity of Dalmatia and not

\footnotetext{
${ }^{52}$ Gračanin and Škrgulja, "The Ostrogoths", 183-184. However, it has to be noted that the term Pannonia for Pannonia Secunda also appears in the Notitia dignitatum in partibus Occidentis 1.51, in Notitia dignitatum. Accedunt Notitia urbis Constantinopolitanae et Latercula provinciarum, ed. Otto Seeck (Berlin: Weidmann, 1876; Frankfurt am Main: Minerva, 1962); La Notitia dignitatum: nueva edición crítica y comentario histórico, ed. Concepción Neira Faleiro (Madrid: Consejo Superior de Investigaciones Científicas, 2005).

${ }^{53}$ On the Anonymous Cosmographer of Ravenna, see Franz Staab, "Ostrogothic Geographers at the Court of Theodoric the Great: A Study of Some Sources of the Anonymous Cosmographer of Ravenna", Viator 7 (1976): 27-58 (for the date: p. 31); Idem, Reallexikon der Germanischen Altertumskunde, vol. 11, 2nd ed. (Berlin \& New York: de Gruyter, 1998), 102-109 (for the date: p. 104), s.v. Geograph von Ravenna.

${ }^{54}$ Ravennatis Anonymi Comographia 4.20, in Itineraria Romana II, ed. Joseph Schnetz (Leipzig: B. G. Teubner, 1940), 1-110.

${ }^{55}$ Cf. Cassiodori Senatoris Variae, ed. Mommsen, 508, s.v. Savia; Cassiodori Variarum libri XII, ed. Fridh, 142, 175, 192, 194, 355.
} 
far from Pannonia, and lists Suavia among the provinces of Illyricum, while Procopius of Caesarea distinguishes between the Siscians who inhabit, together with the Suevi (not those subject to the Franks), the interior above Liburnia, Histria and Venetia, and the Pannonians who live to the east of the Noricans, hold the town of Sirmium and extend to the Danube, and likewise mentions Souabia, where two Gothic commanders recruited troops among unnamed barbarians (likely the Suevi of whom he spoke earlier) before advancing towards Salona. ${ }^{56}$ This would lead to an assumption that the former late Roman province of Savia was known in Ostrogothic times as Suavia due to what is likely to be a sufficiently large enough group of the Suevi settled in the region to give the province a new name and that this may well be the reason why the province seems not to have been regarded as a part of Pannonia any longer. ${ }^{57}$ Finally, the province of Dalmatia appears in the letters several times in plural form (7.24 titulum; 9.8.1; 9.9.1), which is common in late antique and the early medieval sources, and, as a recent detailed study has shown, refers to a special separate status of the region of Liburnia within the province of Dalmatia going back to the late second century. ${ }^{58}$ However, the Variae provide no evidence to support an assumption that the Ostrogoths revived its special status, in spite of the fact that the Anonymous Cosmographer of Ravenna makes it a region in its own right (patria), not even connecting it geographically to Dalmatia as he connects Liburnia to Istria, and that Procopius of Caesarea also separately lists Liburnia among regions on the eastern Adriatic, along with Praevalis, Dalmatia and Istria. ${ }^{59}$ Even though it is rather unrewarding to make an assumption $e$ silentio, the very fact that there is no trace in the Variae (or any other source) of an Ostrogothic age official in charge of Liburnia, which one would expect to have existed if the region held such an importance for the Ostrogoths, at least an office holder similar to the comes insulae Curitanae et Celsinae, may be taken as an argument to the contrary. In other words, the Ostrogoths seem to have been aware of the special status of Liburnia (as alluded to in plural form of the province of Dalmatia), yet did not acknowled-

\footnotetext{
${ }^{56}$ Jordanes, Getica 273; with Jordanes, Romana, 218, in: Iordanis Romana et Getica, ed. Theodor Mommsen, (Monumenta Germaniae Historica. Auctores Antiquissimi 5.1) (Berlin: Weidmann 1882); Procopius, Bellum Gothicum 1.15.26-27; 1.16.8-9, in: Procopius Caesariensis, Opera omnia II (De bellis libri V-VIII: Bellum Gothicum), ed. Jacob Haury, rev. Gerhard Wirth (Leipzig: B. G. Teubner, 1963).

${ }^{57}$ Cf. Gračanin and Škrgulja, "The Ostrogoths", 182, with note 93 on the hypothesis of the Suevic settlement in Savia. See also Wolfram, Die Goten, 320 who thinks that the province of Savia was heavily suevicisized.

${ }^{58}$ Ivan Basić, "Dalmatiae, Dalmatiarum: a study in historical geography of the Adriatic (in the light of the new inscription from Córdoba)", in: Illyrica Antiqua II: in honorem Duje Rendić-Miočević. Papers from the international conference held in Sibenik 12-15 September 2013 (Zagreb: FF press, 2015), forthcoming.

${ }^{59}$ Ravennatis Anonymi Comographia 4.16 (Dalmatia); 4.22 (Liburnia); Procopius, Bellum Gothicum 1.7.36; 1.15.25; 1.16.12. For the hypothesis of a particular importance of Liburnia for the Ostrogoths, see Medini, "Provincia Liburnia”, 393-427.
} 
ge this in administrative terms, but only recognized it in geographic sense. This explanation may perhaps be further substantiated by the circumstance that Cassiodorus also refers to Dalmatia in singular form and that when the term provinciae in plural is used, it relates to Dalmatia and Savia taken together.

The Variae directly mention only one provincial capital, Siscia in Savia (4.49 titulum). However, the phrases Salonitanes milites (1.40) and expeditio Sirmiensis (8.10.4) obviously refer to other two capitals, Salona in Dalmatia and Sirmium in Pannonia Sirmiensis. Sirmium seems to have been attached with a particular importance, which derives from the fact that the entire campaign that ended with the conquest of the former Roman province of Pannonia Secunda is called "the Sirmium expedition." To be sure, at the time of the expedition the city was the seat of Gepidic king, which makes it natural that the possession of Sirmium was a primary goal, and the province was actually wrestled from the Gepids, but this does not contradict the notion that the Ostrogoths considered the city very important in its own right. Ennodius says in his Panegyricus to Theoderic that "the city of Sirmium was once a frontier of Italy" (Sermiensium civitas olim limes Italiae fuit), indicating the strategic importance of southern Pannonia and its road network for the defense of Italy. ${ }^{60}$ Sirmium was also frequented by Roman emperors of old and served as an imperial residence, and may have even been a seat of Ostrogothic kings from the earlier Pannonian times of the Ostrogoths. ${ }^{61}$ Building upon all this, it becomes clear why Theoderic would consider Sirmium a most valuable asset, albeit this is only incidentally reflected in the Variae. ${ }^{62}$

The letters specify on a variety of local functions and offices existing in the provinces, which is telling both of the Ostrogothic administrative innovations and the survival of the central and urban provincial administration from the Roman time: ${ }^{63}$

comes provinciae: 1.40 titulum (comes); 3.23 titulum (comes); 3.26 titulum (comes); 7.24 .2 (comites provinciae); 9.8 titulum (comes); 9.9 .1 (illustris comes),

${ }^{60}$ Ennodius, Panegyricus dictus clementissimo regi Theoderico, 12.60, in: Christian Rohr, Der Theoderic-Panegyricus des Ennodius (Hannover: Hahnsche Buchhandlung, 1995); Magno Felice Ennodio, Panegirico del clementissimo re Teoderico (opusc. 1), ed. Simona Rota (Roma: Herder, 2002). The rest of Ennodius' sentence particularizes on this: "in which (sc. the city of Sirmium) the earlier lords kept guard lest the heaped up wounds from adjacent peoples on that side should protrude into the Roman body" (in qua seniores domini excubabant, ne coacervata illinc finitimarum vulnera gentium in Romanum corpus excurrerent). Theoderic thus becomes a guardian of the Roman territory, a role that equals him with the Roman emperors.

${ }^{61}$ Cf. Gračanin and Škrgulja, “The Ostrogoths”, 174 (note 47), 177.

${ }^{62}$ Cassiodorus is more explicit in his Chronicle, a. 504, even though the langugae is terse, which is characteristic of the genre (Cassiodoris Senatoris chronica ad a. DXIX, ed. Theodor Mommsen, (Monumenta Germaniae Historica. Auctores Antiquissimi 11, Chronica minora 2) (Berlin: Weidmann, 1894), 109-161): "Under this consul Italy retook Sirmium by the valor of lord King Theoderic after the Bulgars had been defeated" (Hoc cons. virtute dn. regis Theoderici victis Vulgaribus Simirum recepit Italia).

${ }^{63}$ See also, Wozniak, "The Continuity of Roman Traditions", 375-377. 
also referred to as praesul: 7.24.2;

comes Gothorum: 5.14.8;

comes insulae Curitanae et Celsinae: 7.16 titulum,

also referred to as prior and iudex: 7.16.1;

consularis provinciae Dalmatiae: 5.24 titulum;

curiales: 4.49 titulum; $5.14 .3 ; 5.14 .5$;

defensores: 4.49 titulum; 5.14.3; ${ }^{64}$

domestici comitis Gothorum: 5.14.8;

iudex: 7.24.2-3;

iudex Romanus: 5.14 .7 (iudices);

iudices provinciae: 3.23 .1 (iudices); 3.23 .4 (iudices, iudex); 5.14.5; 9.9.1 (iudex);

princeps Dalmatiarum: 7.24 titulum; 7.24 .3 (princeps);

tabularius: 5.14.4;

vicedomini: 5.14.8.

There is one instance in which the letters refer to a special group of people that is likely to also had a role in the provincial administration:

capillati: 4.49 titulum.

The letters also mention officials that are not related to the local provincial administration in Dalmatia and Pannonia:

comes: 3.25 titulum;

saio: 5.10 titulum;

comes patrimonii nostri: 9.9.3;

tribuni maritimorum (Venetiae): 12.24 titulum.

Finally, there seems to be two instances in which the letters refer to the Gothic troops in the region:

milites Salonitani: 1.40,

also referred to as miles, defensor armatus: 1.40 ;

defensores: $5.14 .5 .^{65}$

${ }^{64}$ The phrase antiqui defensores of 3.23.2 refers to the Ostrogoths as former defenders of Pannonia Sirmiensis during the first period of their dominance in the region.

${ }^{65}$ As opposed to the mention of defensores in 5.14.3, where they are cited together with curiales and possessores in relation to tax obligations, the defensores of 5.14 .5 are cited after the curiales, which is never the case in the Variae where the defensores civitatis are meant (cf. 2.17 titulum; 3.9 titulum; 3.49 titulum; 4.45 titulum; 9.10 titulum). Beat Meyer-Flügel, Das Bild der ostgotisch-römischen Gesselschaft bei Cassiodor. Leben und Ethik von Römern und Germanen in Italien nach dem Ende des Weströmischen 
At the peak of the provincial administration stood a comes provinciae. ${ }^{66}$ Dalmatia and Savia were governed by a comes (provinciarum) Dalmatiarum atque Saviae, and Pannonia Sirmiensis by a comes (provinciae) Pannoniae Sirmiensis (the Variae however do not specify on the exact names of these offices, but they can be deduced). It may be presumed that, at some point, there also existed a comes (provinciae) Saviae. As is evident from the letters, the provincial comites held the rank of illustres, i.e. a comitiva primi ordinis (cf. 6.12). They had an overall military and civil authority, as is clearly indicated in the selected letters: "protect the province entrusted to you by arms, order it by law," commissam tibi provinciam armis protege, iure compone (3.23.2); "the power is indeed given to the comes of provinces," comiti quidem provinciarum potestas data est (7.24.2); "we wish to destine for provinces such men who are gifted in arms and remarkable for justice," provincias tales viros cupimus destinare, qui sunt armis praediti et iustitia gloriosi (9.9.1). ${ }^{67}$ Their principal task was to ensure peace, order and security of the provinces they governed and provide justice for the inhabitants (3.23.3-4). Cassiodorus refers to a comes provinciae as praesul (7.24.2). The term iudices provinciae in the letter 5.14 as well as more general terms iudex or iudices (once rendered as nostri iudices) in the letters 3.23 and 9.9 seem to refer also to the provincial comites.

A comes Gothorum from 5.14.8 is a high-ranking Gothic official, whose jurisdiction appears to have been confined to the province of Savia, and therefore he may have been a military comes civitatis of Siscia (cf. infra in the prosopographical section, s.v. Severinus). The comes Dalmatiarum atque Saviae, who held the overall military and civil administrative authority in both Dalmatia and Savia, is presumably one of the iudices provinciae mentioned in 5.14.5, and thus not a candidate for this comes Gothorum. As is evident from the name of the office, the comes Gothorum was in charge of the Goths who lived in his province, which is a clear indication of the Goths' presence in Savia. ${ }^{68}$

Reiches (Bern et al.: Peter Lang, 1992), 309, believes them to be the defensores civitatis. On the other hand, Amory, People and Identity, 414-415, says that Severinus's task was to ease tensions between soldiers and civilians.

${ }^{66}$ On the comes provinciae, see Ausbüttel, Die Verwaltung, 209-210; Maier, Amtsträger, 218-222.

${ }^{67}$ It has been suggested that this uniting of supreme military and civil powers vested in one official within the Ostrogothic system of administration was confined to the more exposed frontier areas and outlying provinces. Cf. Schmidt, "Die comites Gothorum", 130; Idem, "Zur Geschichte Rätiens unter der Herrschaft der Ostgoten", Zeitschrift für schweizerische Geschichte 14 (1934): 451-452; Ausbüttel, Die Verwaltung, 209-210; Maier, Amtsträger, 218. There are no evidence in the Variae or elsewhere for Ostrogothic comites provinciae in Gaul, but, on the line of the same reasoning, they are perhaps likely to have existed. Or such a function in Gaul was exercised by comites civitatis in charge of extended jurisdictional area, like the comes civitatis of Massilia who had both military and civil authority $(3.34 ; 4.12$; 4.46). One such is also known from Italy, the comes civitatis of Syracuse to whom the administrative care of the entire province of Sicily was entrusted and who also had both military and civil authority (7.22, with $9.10 ; 9.11 ; 9.14)$. Another such comes civitatis may have been the one in charge of Siscia, who seems to have co-existed with the comes provinciae Dalmatiarum atque Saviae.

${ }^{68}$ On the comes Gothorum, see Maier, Amtsträger, 210-216; with Tabata, "I comites Gothorum", 67-78. 
Another comes that belonged to the provincial administration was the comes insulae Curitanae et Celsinae. It has already been proposed that this comes had only a civil judicial authority and that he was not invested with a military command as is usually believed in scholarship. He was subordinated to the comes Dalmatiarum atque Saviae in both military and civil matters and presumably also obliged to coordinate with the consularis provinciae Dalmatiae in civil matters, but was not subject to the authority of the princeps Dalmatiarum and probably had its own princeps officii. ${ }^{69}$

The consularis provinciae Dalmatiae was the highest-ranking civil official in the province of Dalmatia, whose authority extended exclusively over the Roman population. The letter 5.24 shows him entrusted with legal matters involving the possessores. As a rector provinciae he was also resposible for tax collection (cf. 6.21.3). ${ }^{70}$ The term iudex Romanus from the letter 5.14 refers to a Roman provincial governor, and since the province in question is Savia, he may have been the corrector Saviae, if the Roman name for the office survived (for instance, the governor of Italian province Lucania et Bruttii was still called corrector, cf. 3.8 titulum; 3.47.1). ${ }^{71}$ The post was of senatorial rank. He is obliged to visit once a year every single town (unumquodque municipium) in his province and not to charge for his expenses more than three days' annonae (5.14.7). It can only be speculated whether or not Pannonia Sirmiensis also had a Roman civil governor (he would be a consularis), since the Variae offer no evidence, but it is possible even if this was a frontier province. ${ }^{72}$

The princeps Dalmatiarum headed the officium of the comes Dalmatiarum, i.e. the comes Dalmatiarum atque Saviae. ${ }^{73}$ Since the Variae indicate that there was more than one princeps in the service of a comes, whether he be a comes provinciae $(7.25)$ or a comes civitatis $(6.25 ; 7.28)$, it has been suggested that a princeps may have been assigned to each major city, or that there were two principes in the

\footnotetext{
${ }^{69}$ The formula for the appointment of the princeps Dalmatiarum is placed sufficiently far after the formula for the appointment of the comes insulae Curitanae et Celsinae to warrant such an assumption.

${ }^{70}$ Burns, A History, 174 errs when he makes the governer of Dalmatia a praeses. Cf. Ensslin, Theoderich, 177.

${ }^{71}$ Ensslin, Theoderich, 177. For the corrector Saviae, see Jenö Fitz, Ladministration des provinces pannoniennes sous le Bas-Empire romain (Bruxelles: Latomus, 1983), 20-21, 54.

72 Wolfram, Die Goten, 291 thinks that it did not have, since the comes Colosseus exercised both military and civil authority. Yet, the comes Dalmatiarum atque Saviae also exercised supreme military and civil authority in his provinces, and they both seem to have had their respective Roman civil governors.

${ }^{73}$ It is interesting to note that Matijašić, Povijest hrvatskih zemalja u kasnoj antici, 173, assumes that the princeps Dalmatiarum may have actually replaced the provincial consularis as an official in charge of civil judicial matters. He belives that the provincial comes may have had two immediately subordinate officials at his disposal, one that was probably Roman and in charge of civil matters, and other that was Goth and charged with military command. Wozniak, "The Continuity of Roman Traditions", 377-378, has similarly thought that the princeps Dalmatiarum was the most important Roman official in Dalmatia.
} 
officium of a comes, one responsible for civil matters and the other for military matters, or that there perhaps may have even existed two officii. ${ }^{74}$ Some scholars have inferred that the letter 7.25 is equally addressed to the comes of Dalmatia, meaning that he was to receive at least two principes from the king's officium. ${ }^{75}$ Hence, it may be hypothesized that the comes Dalmatiarum atque Saviae had two separate officii at disposal for each of the provinces he was in charge of. Such an arrangement would surely be in effect only when there was no other comes Gothorum in control of Savia, since he would have his own officium and a princeps to head it (one such was likely to have been Fridibadus, 4.49). Alternatively, if the comes from the letter 7.25 is the comes Dalmatiarum atque Saviae, it may be that the other principes recommended to him were actually intended for the officii of civil governors (the consularis Dalmatiae and the corrector Saviae) as well as of the comes of Krk and Cres Islands. Be that as it may, there seems to have been only one princeps Dalmatiarum at a specific point of time, otherwise one would expect that the letter 7.24 explicitly mentioned the office holder in plural. ${ }^{76} \mathrm{His}$ main task was to maintain a properly functioning legal system in the province. He was in charge of the access to the audience hall (secretarii accessus); supervised the solemn procedure of petitioning (postulationis pompa); and was in control of the provincial judiciary - incidentally, this appears to be the only occasion that the term judex from the selected letters refers to a judge (7.24.2-3) and not to a high-ranking official.

The domestici comitis Gothorum were officers from the officium of a comes Gothorum, who acted as his personal assistants. ${ }^{77}$ In this particular case, the domestici of the comes civitatis of Siscia are likely to have been meant. The domestici were personally picked and appointed by their comes, and were persons of his particular trust. As the letter 5.14 shows, they could engage in abuses against the provincials, which are perhaps unlikely to have been committed without the comes' knowledge. ${ }^{78}$ The letters also refer to two other provincial civil servants, both of whom were active in Savia. The tabularius, an accountant officer, is likely to have belonged to the officium of the comes civitatis of Siscia and he is said to have received money from the royal treasury to be used for the benefit of the local administration, but this act of the royal liberalitas was suppressed by few as stolen gain (furtivum compendium), since the unjust withholder (iniustus retentator) did not put money to its intended purpose (5.14.4). The vicedomini seem to have

\footnotetext{
${ }^{74}$ Burns, A History, 174 (cf. Hodgkin, The Letters, 335, note 3); Ausbüttel, Die Verwaltung, 205; Stein, "Untersuchungen", 180-181.

${ }^{75}$ Schmidt, "Die comites", 129; Stein, "Untersuchungen", 181-182. Cf. 7.25.2: ex officio nostro.

${ }^{76}$ For just one princeps Dalmatiarum, cf. Maier, Amtsträger, 218-219.

77 On the domestici, see Schmidt, "Die comites Gothorum", 129-130; Stein, "Untersuchungen", 384; Maier, Amtsträger, 128-129. Ensslin, Theoderich, 195, appears to think that a comes had only one domesticus at disposal, which does not seem right.

789.13 also refers to abuses of the domestici who serve the comites.
} 
been provincial agents of the comes patrimonii in charge of royal estates in Savia and mentioned, along with the domestici, as inflicting injuries to the provincials $(5.14 .8){ }^{79}$

The letters also mention members of municipal administration, the defensores (civitatis) and curiales. A defensor civitatis was elected by the citizens from among the provincial honorati (former high-ranking state officials) or municipal principales (leading members of the curia), ${ }^{80}$ appointed by the king, and given charge of city affairs. According to the Variae, this primarily meant the control of commercial activities and prices as well as the protection of citizens from legal oppresion and high prices (7.11). However, a defensor civitatis also had fiscal and judicial duties. ${ }^{81}$ As members of a city council, the curiales constituted the urban elite, from among which city officials were selected. The Variae are especially concerned with the protection of curiales from various oppressions and abuses to which they were exposed. Nevertheless, they themselves seem to have been capable of such acts against the possessores (cf. 5.14.5). ${ }^{82}$

A somewhat obscure group that may have also had a role in provincial administration are the capillati. This is the only instance in which they figure in the $\mathrm{Va}$ riae. The term itself is known from other sources. Jordanes, Getica, 72, connects it to the Goths, and the Edictum Theoderici, 5, uses it for a special rank of barbarians who were allowed to refuse a judicial summons. There are earlier instances when the term appears in sources: Pliny the Elder, Natural History 3.5.47, 135, calls the Alpine nations of northern Italy the Capillati. ${ }^{83}$ It has been inferred that the term signifies the free Germans capable for military service; that it relates to the Gothic troops as well as describes barbarians in Gothic army; that it pertains

\footnotetext{
${ }^{79}$ I here understand the word vicedomini to be nominative plural and not genitive singular relating to domestici that are mentioned in conjunction with a comes Gothorum. On the vicedomini, see Ensslin, Theoderich, 166. On the other hand, Arnold Hugh Martin Jones, The Later Roman Empire, 284-602: A Social, Economic, and Administrative Survey, vol. 3, Oxford: Basil Blackwell, 1964, 49 (note 44), has interpreted vicedomini to be genitive singular and to refer to only one provincial agent of the comes patrimonii. Stein, "Untersuchungen, 386-387, has thought vicedominus to be in charge of royal estates in Sicily and Dalmatia. Similarly Delmaire, Largesses sacrées, 692.

${ }^{80}$ It should be noted that both of these terms were interchangable and could actually designate the same local elite (cf. Sebastian Schmidt-Hofner, Reagieren und Gestalten. Der Regierungsstil des spätrömischen Kaisers am Beispiel der Gesetzgebung Valentinians I. (München: Verlag C.H. Beck, 2008), 148, note 88).

${ }^{81}$ On the defensor civitatis under the Ostrogoths, see Ausbüttel, Die Verwaltung, 214-215; Sean D. W. Lafferty, Law and Society in the Age of Theoderic the Great. A Study of the Edictum Theoderici (Cambridge; New York: Cambridge University Press, 2013), 111-113; Maier, Amtsträger, 280-281; Meyer-Flügel, Das Bild, 308-309; Sebastian Schmidt-Hofner, "Der defensor civitatis und die Entstehung des Notabelnregiments in den spätrömischen Städten", in: Chlodwigs Welt. Organisation von Herrschaft um 500, eds. Mischa Meier and Steffen Patzold (Stuttgart: Franz Steiner Verlag, 2014), 487-522, esp. 512-521. Cf. also Leonard A. Curchin, "The end of local magistrates in the Roman Empire" Gerión 31 (2014): 271-287, esp. 281-283.

${ }^{82}$ On the curiales under the Ostrogoths, see Ausbüttel, Die Verwaltung, 210-212; Meyer-Flügel, Das Bild, 310-317.

${ }^{83}$ Cf. Amory, People and Identity, 94, 345-346; Lafferty, Law and Society, 36.
} 
to the Goths in general; that it denotes the Gothic soldiers who were living in Italy; or that it refers to the Suevic nobility in Savia and not to the Goths at all. ${ }^{84}$ The term capillati seems to have been used exclusively for groups of people that lived in the Ostrogothic Kingdom. Whereas the capillati of the Edictum Theodorici may have been the Goths, since the term barbarus is used in such a meaning in the code, this is not so likely for the capillati of the Variae. ${ }^{85}$ Contrary to what has sometimes been suggested, the Goths are never referred to as barbari in the Variae ${ }^{86}$ And there is no reason for Cassiodorus not to have explicitly mentioned the Goths as one of the letter's addressees if they were really meant under the term capillati. Who then might have been the capillati of the Variae? It seems that this was a legal and professional designation based upon a distinguished trait in personal appearance and therefore a cover term for various non-Roman groups that enjoyed a special status under the Ostrogothic rule. In the case of Savia, it may be hypothesized that the capillati included the Suevi, but also other free barbarians who were residing in the province, or perhaps even the Roman provincials who were willing to accept a new identity. Since the capillati are cited before the defensores and curiales, they seem to have held precedence over them and probably exercised a concrete function in the administration of the province. It has been proposed that they were entrusted by the Goths to maintain order in the barbarized areas and might have been counted among the possessores. ${ }^{87}$ This is quite possible since their label as capillati implies the right to freely carry arms. Thus they might have been a provincial militia recruited from the local non-Roman population and used by Gothic authorities for policing duties ${ }^{88}$ Presumably, there

${ }^{84}$ Ensslin, Theoderich, 189; Wolfram, Die Goten, 301; Meyer-Flügel, Das Bild, 76; Amory, People and Identity, 346; Lafferty, Law and Society, 37; Friedrich Lotter, Völkerverschiebungen im Ostalpen-Mitteldonau-Raum zwischen Antike und Mittelalter (375-600). Under collaboration by Rajko Bratož and Helmut Castritius. Berlin; New York: Walter de Gruyter, 2003, 125.

${ }^{85}$ For the term barbarus in the Edictum Theoderici, see Lafferty, Law and Society, 41-43.

${ }^{86}$ Cf. Meyer-Flügel, Das Bild, 54-65. Lafferty, Law and Society, 42, believes that Cassiodorus twice refers to the Goths as barbarians (cf. also Amory, People and Identity, 79, note 188). The first instance he cites, an address to the barbarians and Romans residing in Pannonia Sirmiensis (3.24), actually refers to all other non-Roman inhabitants of the province, the Goths excluded, since it is clear from the text itself that the barbarians and Romans are called to forgo their non-civilized ways and look up to the Gothi nostri who are obviously contrasted to both of them. The other instance, the same which Ensslin 1959, 189 has also adduced as an example that Theoderic's chancellery used the term barbarus to denote Goth, relates to the restitution of a property owned by a Roman, which had been seized by a barbarian usurper, without a written permission, after Theoderic's crossing of the river Isonzo, to its rightful owner (1.18.2). As already stressed by Meyer-Flügel, Das Bild, 64, it cannot be entirely excluded that the Goths are also meant, in which case the term praesumptor barbarus should surely be understood as a derogatory qualification for a deed that is unbecoming of a Goth. On the other hand, other non-Roman groups seem more likely to have been meant, both those who already lived in Italy under Odoacer's rule and those who came to Italy with Theoderic. On the use of the term barbarus in the Variae, see also Lorenzo Viscido, "Sull'uso del termine barbarus nelle 'Variae' di Cassiodoro", Orpheus 7 (1986), no. 2: 338-344.

${ }^{87}$ Lotter, Völkerverschiebungen, 125.

${ }^{88}$ It should be noted that in Gračanin and Škrgulja, "The Ostrogoths”, 184, the term capillati is associated with the term defensores as a single semantic unit and believed to signify the provincial troops over 
were not many Gothic troops left in Savia after the conquest of Pannonia Sirmiensis (it may be assumed that these troops were exclusively garrisoned in Siscia as the provincial capital) and the capillati were perhaps supposed to compensate for that lack. However, if this is the case, the letter shows that they were not very successful, possibly being also a part of the problem.

Of the offices not pertaining to provincial administration, the letter 3.25 mentions a comes, styled vir clarissimus, without specifying on his concrete sphere of authority. Considering the character and scope of his mission, he is likely to have been a comes on a special assignment commissioned by the king (cf. infra in the prosopographical section, s.v. Simeonius). ${ }^{89}$ A saio is referred to in connection with the passage of the Gepids through northern Italy. The saiones seem to have been special commisioners who performed various military and civil task in the service of the king. ${ }^{90}$ The unnamed vir illustris comes patrimonii who is referred to in the letter 9.9 is said to have been ordered by King Athalaric to remit to the Gothic and Roman inhabitants of the provinciae Dalmatiae what has been owed for the fourth indiction (1 September 525 - 31 August 526) as an extra levy (augmentum) on occasion of his accession to the throne. ${ }^{91}$ The mention of the comes patrimonii in this context is an indication that the province of Dalmatia was governed by Ostrogothic kings as their patrimony (which was surely also the case with both Savia and Pannonia Sirmiensis). ${ }^{92}$ The tribuni maritimorum mentioned in the letter 12.24 seem to have been officers in charge of the settlements

which Fridibadus held the authority. Even though the common disassociation of the capillati and the defensores has been adopted in the present study, it seems to me that it cannot be entirely excluded that the letter was actually addressed to all provincials (universi provinciales), longhaired defenders (capillati defensores) and councilmen (curiales). This would perhaps make the capillati of the Variae local standing troops with defensive and order maintaining tasks, which could then also include the locally residing Goths. See also Ausbüttel, Die Verwaltung, 206, who even suggests that Gothic soldiers may have been meant in other instances in which the defensores are the letters' addressees, since they are always mentioned in plural (312, note 9). This is however unlikely. Schmidt-Hofner, "Der defensor civitatis", 512 (note 68), seems to be right when inferring that the plural is to be explained as a standardized formula of address, at least in cases when the letters are directed to particular towns $(2.17 ; 3.9 ; 3.49 ; 4.45 ; 9.10)$.

${ }^{89}$ On the comites on special assignments, see Thomas S. Burns, The Ostrogoths: Kingship and Society (Wiesbaden: Franz Steiner Verlag, 1980), 115-117, Idem, A History of the Ostrogoths, 178-179; Maier, Amtsträger, 161-163.

${ }^{90}$ On the saiones, see Barnwell, Emperor, Prefects \& Kings, 144-145; Burns, Ostrogoths, 114-115; Idem, A History, 178-179; Maier, Amtsträger, 169-181; Meyer-Flügel, Das Bild, 466-469; Wolfram, Die Goten, 294; with Roberto Morosi, "I 'saiones', speciali agenti di polizia presso i Goti", Athenaeum 59 (1981): 150-165.

${ }_{91} \mathrm{He}$ is probably to be identified with the comes patrimonii Bergantinus who is mentioned in 8.23 and 9.3 (cf. Martindale, The Prosopography, 225), and may have been appointed to his post on 1 September 526.

${ }_{92}$ Cf. Stein, "Untersuchungen”, 386; Wozniak, “The Continuity of Roman Traditions", 378. A similar testimony for Savia seems to have also been provided by the Variae, since the provincial tabularius of Savia is said to have received money from the royal cubiculum, that is to say, from the king's personal purse (5.14.4). 
in the lagoon area of the province of Venetia. ${ }^{93}$ As the letter indicates, they were subject to the jurisdiction of the praefectus praetorio Italiae and were presumably confirmed in their office by Gothic authorities..$^{94}$ It has been inferred that the office of tribuni maritimorum also existed in Dalmatia. ${ }^{95}$ This cannot be entirely excluded, it may even be presumed as likely, but the extant sources offer no evidence to support such an assumption.

The Variae also explicitly confirm that the Goths had troops stationed in Dalmatia. The letter 1.40 refers to the Salonitani milites, obviously soldiers garrisoned in the provincial capital. ${ }^{96}$ Their commander, the comes Dalmatiarum atque Saviae, is instructed to watch that soldiers are equipped with arms which should be distributed while there is still no pressing necessity and that they are regularly exercised, since a soldier should learn in peace what he can accomplish in war (discat miles in otio, quod perficere possit in bello). ${ }^{97}$ The defensores from 5.14 .5

${ }_{93}$ Cf. Arnaldo Marcone, "Comment to 12.24", in: Flavio Magno Aurelio Cassiodoro Senatore, Varie, vol V: Libri Xi-XII, eds. Andrea Giardina, Ciovanni Alberto Cecconi, and Ignazio Tantillos, Roma: "L'Erma" di Bretschneider, 2015, 291; Benedikt Hasenstab, Studien zur Variensammlung des Cassiodorius Senator. Ein Beitrag zur Geschichte der Ostgotenherrschaft in Italien (München: Akademische Buchdruckerei von F. Straub, 1883), 43, believes their post to be an old Roman office that corresponds to the tribunatus provinciarum (cf. also Theodor Mommsen, "Ostgotische Studien", in: Idem, Gesammelte Schriften, vol. 6 (Berlin: Weidmanische Buchhandlung, 1910), 435, with note 2, who says that they were probably in charge of provinces of Flaminia and Venetiae). Ludo Moritz Hartmann, Geschichte Italiens im Mittelalter, vol. II/2: Die Loslösung Italiens vom Oriente (Gotha: Friedrich Andreas Perthes, 1903, repr. Hildesheim: Georg Olms Verlag, 1969), 102-103, sees in the tribuni maritimorum financial officers in the service of finance minister. Ruggini, Economia e società, 347 (note 405), connects the tribuni maritimorum to the navicularii maris Hadriatici of previous centuries (on the latter, cf. Angelo Pellegrino, "I navicularii maris Hadriatici ad Ostia", Miscellanea greca e romana 11 (1987): 229-236; Lietta De Salvo, Economia privata e pubblici servizi nell'Impero romano. I corpora naviculariorum (Messina: Samperi editore, 1992), 430-437; Dorothea Rohde, Zwischen Individuum und Stadtgemeinde. Die Integration von collegia in Hafenstädten (Mainz: Verlag Antike e.K., 2012), 114-115). Roberto Morosi, "Lattività del 'praefectus praetorio' nel regno ostrogoto attraverso le 'Variae' di Cassiodoro, Humanitas 27-28 (1975 - 1976): 90, merely calls the tribuni maritimorum powerful proprietors of ships.

${ }^{94}$ Horatio F. Brown, "Venice", in: The Cambridge Medieval History, vol. IV: The Eastern Roman Empire (717-1453), eds. Joseph Robson Tanner, Charles William Previté-Orton, and Zachary N. Brooke (Cambridge: Cambridge University Press, 1923), 385, believes the tribuni maritimorum to have been appointed by the Goths.

${ }^{95}$ Cf. Wilkes, Dalmatia, 425. See also Ferdo Šišić, Povijest Hrvata u vrijeme narodnih vladara [A History of Croats in the Time of National Rulers] (Zagreb: Naklada školskih knjiga, 1925, repr. Zagreb: Nakladni zavod Matice hrvatske, 1990), 169, who says that the tribuni maritimorum were navigation supervisors who watched over the interests of local population engaged in commerce, fishing and extraction of sea salt (adopted by Balduin Saria, in: Paulys Realenzyclopädie der classischen Altertumswissenschaft, Supplementband 8, Stuttgart, 1956, col. 33, s.v. Dalmatia). A more or less identifcal opinion has been expressed by Wozniak, "The Continuity of Roman Traditions", 381. Suić, Zadar u starom vijeku, 320321 , ascribes to the tribuni maritimorum the supervision of maritimal trade and all other economic activities related to the sea.

${ }^{96}$ Cf. Burns, A History, 193. Wozniak, "East Rome", 376, believes them to be Roman militia and assumes that the Roman population was trusted with arms in the early 510s. However, this is unwarranted and it seems to have been a result of the reliance on Hodgkin, The Letters, 166, without consulting the original source.

${ }^{97}$ Similar views can be found in $1.24 .3,5.23$. On the necessity of a regular military training expressed in the Variae, see Meyer-Flügel, Das Bild, 87-89. 
presumably also refer to regular Gothic troops. It may be assumed that they were garrisoned in Siscia as the provincial capital of Savia. There were troops stationed in Pannonia Sirmiensis that surely outnumbered those in Savia, even though they are not directly referred to. A clear hint to the presence of Gothic armed force in Pannonia Sirmiensis is the fact that its comes is instructed to protect the province by arms so that it may happily receive its former defenders (3.23.2; commissam tibi provinciam armis protege ... ut antiquos defensores recipere laeta possit), and provincials are informed that a man very mighty by name and in vigour is sent to govern them and protect them (3.24.2: nomine viribusque praepotenti gubernationem vestram defensionemque commisimus).

\section{The prosopography}

The Variae mention by name a number of persons that were active or lived in or were connected in their official capacity or otherwise to Dalmatia and Pannonia during the Ostrogothic rule. High-ranking officials and functionaries dominate the prosopographical dossier, which is to be expected. In all, there are fourteen named persons, one of which is a woman and two are minors, a boy and a girl. The list is as follows:

Arator (8.12.3);

Colosseus $(3.23 ; 3.24 .2 ; 4.13 .1)$;

Cyprianus (8.21.3);

Epiphanius (5.24);

Fridibadus (4.49);

Iohanna, widow of Andreas (5.24.1);

Maurentius (4.9);

Osuin $(1.40 ; 3.26 ; 9.8 ; 9.9 .1)$;

Paula (4.9);

Senarius (4.13);

Severinus $(5.14 ; 5.15 .2-3 ; 9.9 .2)$;

Simeonius $(3.25 ; 3.26)$;

Tuluin (8.10.4);

Vera (5.10).

Arator, vir illustris (8.12 titulum), a high-ranking official, later famous as poet. He is said to have been directed from the parts of Dalmatia (directus 
de partibus Dalmatiarum) to the Ravenna court..$^{98}$ This perhaps should be understood as signifying that he previously actually traveled to Dalmatia. ${ }^{99}$ In Ravenna he presented a speech before Theoderic on behalf of the provincials about their needs (necessitates provincialium) and the public interests (utilitates publicae), ${ }^{100}$ which was noted for its eloquence (Arator's embassy is called pomposa legatio and he is said to have accomplished it not with common words, but with a rushing stream of eloquence; 8.12.3: non communibus verbis, sed torrenti eloquentiae flumine peregisti). The provincials were presumably the possessores and curiales who often figure in the Variae as needing protection. ${ }^{101}$ Arator seems to have been temporarily employed by the provincial middleclass elite as an accomplished orator and a person of note to state their plea before the king since he was presumably by then a familiar figure at court. ${ }^{102}$ He started his public career as an advocate and seems to have advanced to a position of judge, but abandoned the practice of law before - perhaps even well before - he undertook his Dalmatian embassy. ${ }^{103}$ It is usually believed that

${ }^{98}$ In Gračanin, "The history of the eastern Adriatic region", 78, Arator's names is mistakenly rendered as Aratus and he is erroneously said to have hailed from Dalmatia.

${ }^{99}$ Interestingly enough, The Oxford Dictionary of Christian Church, eds. Frank Leslie Cross and Elizabeth A. Livingston, revised 3rd ed. (Oxford: Oxford University Press, 2005), s.v. Arator, makes Arator go to Dalmatia in 526 as imperial ambassador. Christoph Schäfer, Der weströmische Senat als Träger antiker Kontinuität unter den Ostgotenkönigen (490 - 540 n. Chr.) (St. Katharinen: Scripta Mercaturae Verlag, 1991), 25 (with note 112), hypothesizes that Arator had close links to Dalmatia and possessions there. See also Rajko Bratož, Med Italijo in Ilirikom. Slovenski prostor in njegovo sosedstvo v pozni antiki [Between Italy and Illyricum. Slovene Territory and Its Neighborhood in Late Antiquity] (Ljubljana: Znanstvena založba Filozofske fakultete; Zveza zgodovinskih društev Slovenije; Slovenska Akademija znanosti in umetnosti, 2014), 384.

${ }^{100}$ For all what could be understood under the utilitates publicae, see Amory, People and Identity, 56-57.

${ }^{101}$ Cf. Meyer-Flügel, Das Bild, 304-306, 315-317.

${ }^{102}$ Schäfer, Der weströmische Senat, 25 (note 114), speculates that Arator retired for quite a while to the country away from political struggles as he did not enjoy a continuing sponsorship of influential personalities, which slowed down his career advancement. Be that as it may, Arator seems to have had a certain influence with the royal court and King Theoderic, otherwise he presumably would have not been chosen by Dalmatian provincials as a suitable person to advance their interests. Arator's position of influence seems to be more in accordance with his overall image that emanates from the letter.

103 "The field of advocacy trained you, the summit of our judiciary elected you (...) though the eloquence carried you along to speak for defence, yet the equity urged you to pronounce judgments (...) by delighting and exciting you rather fulfilled the effort of a true orator since you had by now quit a lawyer's office" (8.12.2-3: advocationis te campus exercuit: te iudicii nostri culmen elegit ... quamvis traheret te eloquentia pro defensione dicere, suadebat tamen aequitas iudicanda proferre ... delectando movendo implebas magis veri oratoris nisum, cum iam causidici deseruisses officium). I take here causidicus to mean a practitioner of law. Richard Hillier, Arator on the Acts of the Apostles. A Baptismal Commentary (Oxford: Clarendon Press, 1993), 7, errs when he says that Arator joined the embassy to Theoderic as an advocate. Similar oversight is made by Klaus Thraede, Reallexikon für Antike und Christentum, suppl. vol. I (Aaron-Biographie II), eds. Theodor Klauser et al. (Stuttgart: Anton Hiersemann, 2001), 555. Some scholars make Arator an advocate at court (cf. Johannes Schwind, Der Neue Pauly. Enzyklopädie der Antike, vol. I (A-Ari), eds. Hubert Cancik and Helmuth Schneider, (Stuttgart \& Weimar: Verlag J.B. Metzlar, 1996), s.v. Arator; Idem, Metzler Lexikon antiker Autoren, ed. Oliver Schütze (Stuttgart \& Weimar: Verlag J.B. Metzler), 1997, s.v. Arator; Idem, Lexikon der antiken christlichen Literatur, eds. Siegmar Döpp and 
this embassy occured in 526. ${ }^{104}$ By then, Arator may have already held the title of comes domesticorum, which was honorary in the West and was conferred to raise the recipient to the status of vir illustris. ${ }^{105}$ Alternatively, he may have first continued to pursue his career as a professional orator following his legal occupation, and received the title of comes domesticorum as a direct result of a flamboyant presentation of his rhetorical talents before the king and state officials (we may presume that Cassiodorus was also present). ${ }^{106}$ In any case, Arator undoubtedly relinquished his legal post after he had received the title of comes domesticorum. He was also conferred a comitiva by Athalaric. The Variae do not specify on the title, but merely say isto honore (8.12.8), which makes the matter somewhat controversial. Some scholars have thought that it was Athalaric who appointed Arator comes domesticorum or that he just confirmed him in the same honor, since isto honore seems to indicate as much. ${ }^{107}$ Others have assumed that Athalaric bestowed the comitiva rerum privatarum on Arator, a title recorded for him in one manuscript tradition. ${ }^{108}$ It is odd that the letter would not concretely mention the office if it really were the comitiva rerum privatarum. Thus, perhaps, isto honore might be interpreted to mean that Arator became a comes primi ordinis for special assignments attached to the royal court, a post that may be styled intra consistorium. ${ }^{109}$ Arator's office would invest him with an authority to perform the "important work" (grande negotium; 8.12.8), with which he is promised to be commissioned. Arator's family background, oratorial skills and legal expertise would surely make him

Wilhelm Geerlings, 3rd ed. (Freiburg-Basel-Wien: Herder, 2002), s.v. Arator), which is quite unlikely, since this would be in direct clash with the late Roman practice (cf. Jones, The Later Roman Empire, vol. 1, 508). Arator was presumably an advocate at the bar of the praefectus praetorio Italiae, one of the most sought after positions in the profession. It is interesting to note that, in the West, the career of an advocate was limited to twenty years and that men of senatorial rank mostly pursued it in their youth as an introduction to acquiring more lofty public offices (Jones, The Later Roman Empire, vol. 1, 508, 510511). Since Arator was of a senatorial family (Martindale, The Prosopography, 127), and seems to have been born around 480 (Claudio Leonardi, Dizionario Biografico degli Italiani, vol. III (Ammirato-Arcoleo), ed. Alberto M. Ghisalberti (Roma: Istituto della Enciclopedia Italiana, 1961), s.v. Aratore; accessed 6 September 2015 at http://www.treccani.it/enciclopedia/aratore_\%28Dizionario_Biografico\%29/), it would be perhaps strange to think that he remained an advocate for so a long period of time.

${ }^{104}$ Cf. Massimiliano Pavan, "La missione in Dalmazia del poeta Aratore", Atti e memorie della Società dalmata di storia patria 13 (1988-1989), 33; Johannes Schwind, Arator-Studien (Göttingen: Vandenhoeck \& Ruprecht, 1990), 10; Thraede, Reallexikon, 555 (around they year 526).

${ }^{105}$ 6.11.2; with Martindale, The Prosopography, 127; Amory, People and Identity, 92. Leonardi, Dizionario, s.v. Aratore, says that Arator was invested with the dignity of comes domesticorum before 526.

${ }^{106}$ See also Pavan, "La missione", 33.

${ }^{107}$ Cf. Paul-Augustin Deproost, L’Apôtre Pierre dans une épopée du VI siècle: l'Historia apostolica d'Arator (Paris: Institut détudes augustiniennes, 1990), 23; Schwind, Arator-Studien, 10; Hillier, Arator, 7-8.

${ }^{108}$ Cf. Mommsen, "Ostgotische Studien", 403-404, note 5; Pavan, "La missione", 37; Martindale, The Prosopography, 127; Leonardi, Dizionario, s.v. Aratore; with Hillier, Arator, 8; Schäfer, Der weströmische Senat, 25.

${ }^{109}$ For Theoderic's consistorium, see Ernst Stein, Histoire du Bas-Empire, vol. 2 (Amsterdam: Adolf M. Hakkert, 1968), 120-121. 
suitable for special missions, particularly for sensitive tasks involving the senatorial aristocracy.

Colosseus, vir illustris (3.23 titulum; 3.23.2: inlustris cinguli dignitate praecinctus; 3.24.2; 4.13), a comes provinciae of Pannonia Sirmiensis. He seems to have been appointed in 510, possibly in the wake of the peace agreement with the Eastern Empire, since he is said to be embarking under favorable omens (3.23.2: prosperis initiatus auspiciis). ${ }^{110} \mathrm{He}$ is called a man very mighty by name and in vigour and said to have shown thus far many examples of his valor (3.24.2: nomine viribusque praepotens qui suae multa dedit hactenus experimenta virtutis) and to have been destined for his province on account of his efforts and merits (4.13: pro laboribus et meritis designatus), which clearly indicates his long-standing military career and fame. ${ }^{111}$ Perhaps he served in the campaign against the Gepids in 504 and the intervention against the Eastern Roman forces in 505. In the letter of his appointment, Colosseus is called upon to nurture the righteousness and defend the innocent by valor of mind against the corrupted practices which destroy the civilized way of life (3.23.3-4), and prevent the conflicts between the barbarians and Romans (3.24.3-4). That he also had to be mindful of his soldiers not to engage in plunder is implied in 4.13.2. Senarius was instructed to provide supplies for Colosseus, since, while the necessities were being prepared for him, the opportunity was denied by unjust presumptions (4.13.1: quatenus, dum memorato viro necessaria fuerint praeparata, locus iniustis praesumptionibus abrogetur), which seems to allude to problems with logistics, even though the true nature of the affair is not deducible. It has been inferred that he belonged to the native barbarian population of Pannonia or that he was a Goth with a non-Gothic name. ${ }^{112}$ Be that as it may, his ethnic identity cannot be concluded based solely on his name.

Cyprianus, vir illustris (8.21 titulum; 8.22.4), vir magnificus (8.22.1), patricius (8.21 titulum; 8.21.7: patriciatus dignitas), a high-ranking official. ${ }^{113} \mathrm{He}$ first rose through military service. He is said to have been seen a warrior by the barbarian Danube and not frightened by a pack of Bulgars who would have prevented the anticipated outcome of the battle. He attacked the resisting barbarians and pursued them when they had turned in terror, thus saving the

\footnotetext{
${ }^{110}$ Cf. Gračanin and Škrgulja, "The Ostrogoths”, 182. Schmidt, "Zur Geschichte Rätiens”, 452, has thought that Colosseus' mandate (and Fridibadus' as well) may perhaps be dated to 508 .

${ }^{111}$ Cf. Martindale, The Prosopography, 305; Amory, People and Identity, 368.

${ }^{112}$ Schmidt, "Die comites Gothorum", 130; Wolfram, Die Goten, 320; Martindale, The Prosopography, 305. Amory, People and Identity, 369, seems to have doubts about Colosseus' being a Goth. On the names of officers in the Gothic army, cf. Amory, ibidem, 97-102; with John Moorhead, Theoderic in Italy (Oxford: Clarendon Press, 1997), 86.

${ }^{113}$ On Cyprianus, see Martindale, The Prosopography, 332-333; Schäfer, Der weströmische Senat, 55-56; Amory, People and Identity, 369-371.
} 
victory for the Goths not so much by number as by effort (8.21.4: Vidit te adhuc gentilis Danubius bellatorem: non te terruit Bulgarum globus, qui etiam nostris erat praesumptione certaminis obstaturus. Peculiare tibi fuit et renitentes barbaros aggredi et conversos terrore sectari. Sic victoriam Gothorum non tam numero quam labore iuvisti). The campaign against the Gepids in 504 and the fight against the Bulgar mercenaries in the army of the magister militum per Illyricum Sabinianus in 505 are meant. ${ }^{114}$ Cyprianus probably held a minor command post at both of these occasions.

EPIPHANIUS, vir spectabilis, a consularis of the province of Dalmatia in 523/526. He received instructions to inquire into a matter of a property that was once owed by a widow named Iohanna, but now illegaly usurped by different people (diversi), since she had reportedly died without testamentary heirs or legal relatives. If this were true, he should claim the property for the state, for it is not becoming to defraud the sovereign, and it would be a falt of negligence to overlook the presumptions which the law instructs to be eradicated. Were he to learn the opposite, he should let the owners have peace, for greater are the royal patrimonies that are legally possessed by subjects (5.24: non fraudari principem decet, quia neglegentiae vitium est praesumptiones relinquere, quas iura praecipiunt amputare. Si quid autem contra reppereris, quietos dominos habere patieris, quia magis illa nostra sunt patrimonia, quae a subiectis legitime possidentur). The letter clearly shows the type of legal and fiscal matters related to the Roman provincial population, with which the civil governor was obliged to deal. ${ }^{115}$

\footnotetext{
${ }^{114}$ Daniel Ziemann, Von Wandervolk zur Großmacht. Die Entstehung Bulgariens im frühen Mittelalter (7.-9. Jh.) (Köln; Weimar; Wien: Böhlau Verlag, 2007), 48-49, errs when he assumes that the Bulgars helped the Gepids to retake Sirmium from the Ostrogoths, since the extant sources do not support such an interpretation.

${ }^{115}$ Epiphanius may have had a predecessor in one vir spectabilis Ausonius who is mentioned in a fragmentary inscription found in the area of Podstrana south of Split in 1976. The inscription reads as follows: ius negabatur ve [nandi vel veniendi?] / nunc temporibus pe[s]- / simis vir spectabili[s].. / Ausonius comis sac[ri] / consistorii et Dalmat[ia] / rum consulens pe[... / ... que]m ho[no / rem]... The inscription has been dated to the late 5th or early 6th century and it seems to indicate that Ausonius was a consularis Dalmatiarum. Cf. Marin Zaninović, "Avsonius vir spectabilis. Novi namjesnik kasnoantičke Dalmacije" [Avsonius vir spectabilis. A New Governor of Late Antique Dalmatia], Prilozi povijesti umjetnosti u Dalmaciji 26 (1987), no. 1: 11-22; with Idem, "Ausonius vir spectabilis. Nuovo luogotenente della Dalmazia tardoantica", in: Actes du IXe Congrès international dépigraphie grecque et latine. Acta Centri Historiae Terra Antiqua Balcanica, vol. II, eds. Aleksandr Fol, Vladimir Živkov and Nikolai Nedjalkov (Sofia: Terra Antiqua Balcanica, 1987), 288. See also Vladimir Posavec, Dalmacija u vrijeme Marcelina i Julija Nepota [Dalmatia in the Time of Marcellinus and Julius Nepos] (Split: Književni krug, 2007), 129; Salona IV. Inscriptions de Salone chrétienne, IV -VII siècles, vol. II, eds. Nancy Gauthier, Emilio Marin and Françoise Prévot (Rome: École Française de Rome; Arheološki muzej Split, 2010), 766-769, nr. 426. Nikolina Uroda, "Beginnings of monasticism on central Dalmatian islands - problems and perspectives", Hortus Artium Medievalium 19 (2013): 114, identifies vir spectabilis Ausonius with a certain Ausonius mentioned in a letter of St. Jerome to Julian dated to 406/407 (Epistula 118.1), but this is unlikely.
} 
FridibADUS, a high-ranking official. His exact title and office are omitted, but he seems to have been put in charge of the entire province of Savia (4.49: locis vestris praeesse, meaning the loci of the provinciales, capillati, defensores, and curiales of Savia and Siscia). He is thought to have been a comes provinciae, or the comes civitatis Sisciae, or an official with only civil judicial authority, or a military comes civitatis in charge of the capillati and acting under the authority of Osuin who held the senior military command. ${ }^{116}$ It seems clear that Fridibadus possessed both civil and military authority, since he obviously held a command over the capillati, and therefore he may have really been the military comes civitatis Sisciae. Alternatively, he may have been a comes Gothorum on a special assignment and may have had a title of vir clarissimus. ${ }^{117}$ In 511 , he was sent to Savia on a mission to check violence and wrongdoings in the province, punish cattle rustlers with proper severity, bring murderers to justice, prevent thefts, and save the peaceful provincials, who were now being crushed by unjust presumption, from criminal acts. It may be assumed that he was to make use of the capillati to accomplish his task.

IoHanna, widow of Andreas. Both she and her husband clearly belonged to the Dalmatian provincial middle class, the possessores. She did not remarry after her husband's death and apparently had no living children. In 523/526, she died intestate and her property was usurped by a number of persons. Since the consularis Dalmatiae is charged to investigate the matter, it may be perhaps assumed that there were no Goths involved in illegal actions. ${ }^{118}$ The letter says that the king was informed of the affair (ad nos perlatum est), presumably through the officium of the comes provinciae.

MaURentius, an orphaned boy, presumably from Dalmatia. He and his sister PAULA were bereft of fatherly protection and falsely accused out of greed by many shameless adults of various offences. Maurentius' and Paula's father was

\footnotetext{
${ }^{116}$ Martindale, The Prosopography, 485; Burns, A History, 175; Lafferty, Law and Society, 72; Andreas Schwarcz, "Der Nordadria - und Westbalkanraum im 6. Jahrhundert zwischen Goten und Byzantiner", in: Slovenija in sosednje dežele med antiko in karolinško dobo. Začetki slovenske etnogeneze / Slowenien und die Nachbarländer zwischen Antike und karolingischer Epoche. Anfänge der slowenischen Ethnogenese, vol. 1, ed. Rajko Bratož (Ljubljana: Narodni muzej Slovenije, 2000), 68; Lotter, Die Völkerverschiebungen, 124; Wolfram, Die Goten, 320; Amory, People and Identity, 376.

${ }^{117}$ Interestingly enough, his mission corresponds with what is said in the Formula comitivae provinciae about duties of a provincial comes: "Let your ensigns frighten cattle rustlers, scare thieves, terrify robbers, and let the innocence observe so happily, while it has confidence that the protection, which the discipline of laws sends, has arrived" (7.1.3: Signa tua abactores timeant, fures pavescant, latrones perhorreant, innocentia tantum laeta respiciat, dum sibi auxilia venisse credit, quae legum disciplina transmisit). This indicates that Fridibadus was given powers of a provincial governor in Savia, with the specific task to eradicate various kinds of thievery and murderous violence.

${ }^{118}$ That high Gothic officials were sometimes tempted to engage in illegal actions and abuses against the leading members of local Roman communities is shown, for instance, by the case of vir sublimis Gildila, comes civitatis of Syracuse (9.14; with Schmidt-Hofner, "Der defensor civitatis", 487-488).
} 
apparently a member of the provincial middle class, the possessores, and similarly as in the case of Iohanna, many were prepared to take advantage of the situation and acquire additional property. Theoderic took the children under his guardianship (praesidium), that is placed them under his special protection (tuitio regii nominis). ${ }^{119}$ The comes Osuin is therefore informed by Theoderic that any contester who prefers to accuse should know that the aforementioned adults are to be directed to the king's court, where both the innocence can find shelter and the calumniators a busy court of law (4.9: supra memoratos adultos, si quis iurgantium pulsare maluerit, ad nostrum comitatum noverit dirigendos, ubi et innocentia perfugium et calumniatores ius possint invenire districtum).

OsuIN, vir illustris (1.40 titulum; 3.26 titulum; 4.9 titulum; 9.8 titulum; 9.9.1); styled illustris sublimitas tua (1.40), prudentia tua (3.26), sublimitas tua (3.26), sublimitas vestra (4.9), illustris magnitudo tua (9.8.1), a comes Dalmatiarum atque Saviae. He is first mentioned in a letter dated to 508, in which he is instructed to procure weapons for troops in Salona and take care of the proper military training for the soldiers (1.40). At that point, he had probably served as the provincial comes for a while. ${ }^{120} \mathrm{He}$ is likely to have been the comes of both Dalmatia and Savia by then. Whether or not he had previously been in charge of only Dalmatia cannot be deduced, but it is perhaps not unlikely. He seems not to have had much time to be concerned with Savia, otherwise there might have not arisen a necessity for Fridibadus to be sent to the province to iron out troubles. The task with which is Osuin first found to be charged in the Variae was obviously a precautionary measure, and, if the year 508 is correct for the date of the letter, it may have to do with the then tensions between the Ostrogothic Kingdom and the Eastern Empire. The expedition of the eastern Roman fleet against southern Italy in 508 seems to have been a part of the pressure that the empire tried to exert on the Ostrogoths. ${ }^{121}$ Osuin thus may have been ordered to keep his troops ready and alert should a military emergency arise. In 510, he was instructed to provide assistance to the vir clarissimus Simeonius. Osuin seems to be somewhat rebuked, since the letter says that, even though it is his to protect those who have been assigned in public interest, the king's admonition nevertheless increases so that it would be more certain when the royal command is respectfully complied with, and Osuin is additionally reminded that he should not deny the expected aid to Simeonius so that Osuin would become more commendable to the king as he hastens to make himself available for public interest (3.26: Quamvis prudentiae tuae

\footnotetext{
${ }^{119}$ Lafferty, Law and Society, 195.

${ }^{120}$ Amory, People and Identity, 403, makes Osuin appointed to his office in 510, which does not seem correct.

${ }^{121}$ Cf. Gračanin and Škrgulja, “The Ostrogoths”, 182.
} 
sit utilitati publicae deputatis ferre praesidium, tamen ammonitio nostra se cumulat, ut securius fiat, ubi se reverentia nostrae iussionis accommodat. ... Cui expetita solacia non negetis, ut sublimitas tua nobis commendatior fiat, cum actibus se publicis praebere festinat). ${ }^{122}$ In 511, he was instructed to defend two orphaned children who were placed under king's protection (4.9). Probably in September 526, Osuin was reappointed to the post of comes Dalmatiarum atque Saviae by Athalaric. It cannot be determined with any certainty when he was previously discharged. ${ }^{123} \mathrm{He}$ may not to have been in office when, in 523/526, the vir illustris Severinus was sent to Savia. Osuin is perhaps meant under the iudices provinciae who abuse the provincials of Savia (or were these Roman civil governors?), unless the plural should be understood here in general sense and referring exclusively to the current governer of Dalmatia and Savia, the one that apparently succeeded Osuin (5.14.5). The latter seems to be more in line with what is said in the letter of Osuin's reappointment, where this decision is referred to as palms of repayment for his honorable efforts (9.8.1: Propositi nostri est honestos labores palma remunerationis ornare). Osuin is told not to seek out examples of others, but to remember what he has done and he will not need be admonished (9.8.2: Non exempla aliena perquiras: memor esto quae feceris et non indiges ammoneri). He may be of advanced age, but could his more mature action now steal away that in which he was not blameworthy as a young man? He has performed such deeds under the reign of Athalaric's grandfather and now he should show the same so that he would make sure to reserve for Athalaric's time whatever additional good he would do (9.8.3: Aetas quidem tua provecta est, sed actus quoque maturior quid tibi nunc subripere valeat, in quo nec iuventus reprehensibilis fuit? Sed haec in domni avi nostri regno fecisti: nunc talia demonstra, ut temporibus nostris reservasse videaris, quicquid probitatis addideris). He is alluded to as a man gifted in arms and remarkable for justice, said to be well-known at the royal court and, due to a long-lasting association, the most familiar with provinces, and referred to as a just man who appropriately maintains the law (9.9.1: qui sunt armis praediti et iustitia gloriosi ... palatio nostro clarum et provinciis longa conversatione notissimum ... Habet enim proprium ius ille qui iustus est). Osuin's career as a provincial comes in Dalmatia and Savia apparently lasted for quite some time. He may have eventually been retired from his office due to his age and then reactivated by Athalaric to help sort things out in the provinces together with Severinus. Perhaps his predecessor in the office of the comes Dalmatiarum

\footnotetext{
${ }^{122}$ Note that Colosseus is also made aware of the honest conduct by which he may commend himself to King Theoderic (3.23.3).

${ }^{123}$ Amory, People and Identity, 403, thinks that Osuin may have held his office during the entire intervening period, from his first mention to his reappointment.
} 
(before Dalmatia was united with Savia) was one Agilulph/Agilulfus who is thought to have been in charge of Dalmatia in the late fifth century. ${ }^{124}$

Paula, an orphaned girl, presumably from Dalmatia, sister of Maurentius. See above under MaURentius.

Senarius, vir illustris (4.3 titulum; 4.4.1-2; 4.7 titulum; 4.11 titulum; 4.13 titulum), a comes patrimonii (4.3; referred to as comes rerum privatarum in the titles of the letters), styled sublimitas tua (4.7.2), illustris sublimitas tua (4.7.3), magnitudo tua (4.11); later he became a patricius. ${ }^{125} \mathrm{He}$ is instructed to provide necessary supplies for the comes Pannoniae Sirmiensis Colosseus who was leaving for his province in 510 . The letter stresses how a hungry army cannot maintain discipline, "for an armed man always takes what he lacks. So let him have what he buys lest he should be forced to think about what to snatch away. Necessity loves not temperate things, nor you can command many what very few can observe" (4.13.2: Disciplinam siquidem non potest servare ieiunus exercitus, dum quod deest semper praesumit armatus. Habeat quod emat, ne cogatur cogitare quod auferat. Necessitas moderata non diligit, nec potest imperari multis quod nequeunt custodire paucissimi).

SeVerinus, vir illustris (5.14 titulum; 5.15.3), styled tua laus (5.15.2), illustris et magnificus (5.15.2), a high-ranking official. He was sent to Savia, but his official capacity is not mentioned. It has been suggested that he was a peraequator, but he must have held a higher post and was probably a comes. ${ }^{126}$ Since he seems to have also had the authority over troops, the defensores (5.14.5), it has been proposed that he was perhaps a military comes and based in some city in the provinces, possibly the comes civitatis of Siscia, considering Severinus region of activity. ${ }^{127}$ However, since he was charged to investigate the domestici of a certain comes Gothorum who may have actually been the comes civitatis of Siscia, Severinus could have held an authority as a comes primi ordinis or perhaps even a comes Gothorum on a special assignment. He was sent to the province by Theoderic in 523/526. ${ }^{128}$ The letter indicates that Severinus was picked out for the mission after many others have failed: "This indeed we wished to

\footnotetext{
${ }^{124}$ Martindale, The Prosopography, 34; Amory, People and Identity, 356-357.

${ }^{125}$ On Senarius, see Martindale, The Prosopography, 988-989; Schäfer, Der weströmische Senat, 103-104; Amory, People and Identity, 413; with Delmaire, Largesses sacrées, 101, 111, 116, 692.

${ }^{126}$ Pavan, "La missione, 31-32; Martindale, The Prosopography, 1001; cf. Amory, People and Identity, 414. ${ }^{127}$ Amory, People and Identity, 414; Gračanin and Škrgulja, "Die Ostrogoths", 184. Lafferty, Law and Society, 110, makes Severinus governor of Savia, which is not likely. Antoljak, "Zadar unter ostgotischer Herrschaft", 212 (note 81), even saw Severinus as iudex Romanus. For the defensores, cf. supra note 82.

${ }^{128}$ Krautschick, Cassiodor (cf. supra note 26), seems to suggest with his redating of the letters 5.14 and 5.15 to 526 that Severinus never went to Savia, but was reappointed to a new post in Dalmatia by Athalaric shortly after Theoderic's death (cf. Amory, People and Identity, 415).
} 
be rectified through very many, but it seems that it may have been deferred for your glory, inasmuch as the trustworthiness would be regarded as more pleasing when you attest most efficiently, after many who neglect it, to your pursuit" (5.14.2: Hoc quidem per plurimos desideravimus corrigi, sed hactenus in tuam laudem videtur potuisse differri, quatenus fides haberetur acceptior, quando post multos neglegentes studium vestrum efficacissime comprobatis). Severinus' task was to introduce righteousness in tax obligations and make sure that the due tax is paid, remedy abuses of possessores against the provincials and punish the offenders, investigate and rectify the wrong done to the possessores by judges, councilmen and soldiers, clarify the case of misappropriation of the funds allocated from the state treasury to the provinces, compel the antiqui barbari who had married Roman ladies and thus obtained estates to pay their due taxes, make sure that the Roman governor does not overburden the provincials with expenses, and resolve the cases of intimidation perpetrated against the provincials by domestici of the comes Gothorum and the vicedomini (5.14.28). ${ }^{129}$ Severinus is said to be noted for his prudence (5.14.2: prudentia, qua notus es) and instructed in royal institutes (5.15.2: nostris institutionibus eruditus), he is alluded to as just and honorable (5.15.2: Vidit enim quam honorabilis apud nos iustus habeatur), and asked to act with mindful justice (5.14.2: considerata iustitia). He is ordered to enter all his findings into public account books (polyptichi) so that both the testimonies of his thrustworthiness would be clear and fraudulent acts would hereafter not be repeated (5.14.9). Probably in September 526, Severinus was sent back to the provinces, simultaneously with the comes Dalmatiarum atque Saviae Osuin (5.15.2). ${ }^{130}$ His task was to inquire into complaints of the universi Gothi sive Romani in the provinces, who are believed by the government to be overtaxed (5.15.4). He is alluded to as vir prudentissimus (5.15.2).

Simeonius, vir clarissimus (3.25 titulum; 3.26), a comes. Possibly in September or October 510, he was sent to Dalmatia to collect arrears of the sales tax siliquaticum due for the period of three fiscal years, and inquire into the possibility of reopening iron mines in interior Dalmatia (3.25). The second Simeonius' task served Cassiodorus to digress into a minor literary bravura on the importance of iron, which is said to be whence the defence of the homeland comes and the fields are made useful, and is offered for use in human life with multiple advantage. "It commands the gold itself and compels the rich to serve the firmly armed poor" (3.25.2: Hinc auxiliante deo patriae defensio venit: hinc agrorum utilitas procuratur et in usus humanae vitae multiplici commoditate

\footnotetext{
${ }^{129}$ Cf. also Lotter, Völkerverschiebungen, 36-37.

${ }^{130}$ Schäfer, Der weströmische Senat, 105, believes that Severinus may have had possessions in the province, which, in his opinion, would explain Severinus' particular familiarity with local affairs.
} 
porrigitur. Auro ipsi imperat et servire cogit locupletes pauperibus constanter armatis). ${ }^{131}$ Simeonius, who is alluded to as honest and loyal in his service (3.25.1), is exhorted to be attentive by the excursus and tempered in public interests so that this lucid summary may bring about for him a rise in that which is to be increased (3.25.2: Esto ergo de antefata discussione sollicitus et in publicis utilitatibus temperatus, ut nostrum rationabile compendium crescendi tibi procurare possit augmentum). The comes Osuin was specifically instructed to assist Simeonius in his mission (3.26). Simeonius' precise office is not specified, but it is clear from both letters that his mandate included responsibilities which were commonly under respective control of the praefectus praetorio (the collection of tax) and the comes sacrarum largitionum (the supervision of mines). Hence he is likely to have been a comes on a special assignment. ${ }^{132}$ This is perhaps additionally confirmed by the fact that he is said to be of a known trustworthiness and tested devotion (3.26: cuius fides olim nobis est cognita vel devotio comprobata), meaning that he must have been entrusted with important missions on previous occasions.

Tuluin, vir illustris (8.9 titulum), styled vir praecelsus (8.10.1), patricius praesens, i.e. praesentalis (8.9 titulum; 8.10.1; 8.10.11; 8.25.2), the highest-ranking military officer in Italy in 526 . He is said to have been directed to the expeditio Sirmiensis and is called a warlike man of whom what had been learned by words was shown in the freedom of camps. He triumphed over the Huns, among others, and, fortunate in first battles, he gained deserved praise killing the Bulgars who are dreadful to the whole world (8.10.4: quod ab illo Martio viro verbis didicerat, in camporum libertate monstraret. Egit de Hunnis inter alios triumphum et emeritam laudem primis congressibus auspicatus neci dedit Bulgares toto orbe terribiles). He participated in the expedition against the Gepids in 504 and fought the Bulgar mercenaries that were employed by the magister militum per Illyricum Sabinianus in 505. He is also mentioned as narrowly escaping drowning when his ship was caught in stormy weather near Aquileia, saved, along with his son, only by the strength of his swimming arms, while other sailors have perished (8.10.9: Cum ventis saevientibus furentem pelagum spuma testaretur undarum, diu iactatum navigium tumens fluctus absorbuit, nullum relinquens forti viro solacium nisi tantum remigia brachiorum. Tunc iste nautis pereuntibus cum caro pignore solus evasit).

Vera (called Veranis in the Variae), a saio. He is styled devotio tua (5.10.2). In about 524 , he was instructed by Theoderic to organize the passage of a contingent of

\footnotetext{
${ }^{131}$ Somewhat different sentiment is expressed in 7.1.3: "A sword is scorned, where the gold is received" (gladius contemnitur, ubi aurum suscipitur).

${ }^{132}$ Bratož, Med Italijo in Iliriko, 385, makes him a regional comes.
} 
the Gepids through northern Italian provinces of Venetia and Liguria to Gaul. Even though this is not mentioned in the letter, the Gepids were on the march from Pannonia Sirmiensis, and perhaps the saio Vera accompanied them all the way from the province. Each Gepidic household (condama) is said to have been given three solidi so that they may buy supplies from provincials, rather than to engage into plunder (5.10.2; cf. 5.11). Vera was charged to watch over the commercial exchange between the possessores and the Gepids so that it would proceed without coercion (5.10.3).

\section{Provincial economy}

The Variae provide a few glimpses into the economic life of the sixth-century Dalmatia and Pannonia. To be sure, only bits and pieces of information are what can be gathered from the letters, but the scarcity of other extant written sources consequently makes them even more valuable. With regard to the amount of available economy-related information in the Variae, however scant it may be, Dalmatia and Savia fared better then Pannonia Sirmiensis, whose dossier is practically non existent. Along with legal and judicial matters, fiscal problems loom large in the letters. What is evident is that two main concerns of the Ravenna government were to secure the regular income from taxation and not to overburden the taxpayers. ${ }^{133}$ The latter concern is shown by Athalaric's government, which sent a commissioner to the provinciae Dalmatiarum atquae Saviae to inquire into the height of the tax rate as a prelude to a stated introduction of a fairer tax load as well as remitted, as an act of royal benevolence, the due surtax for the fourth indiction on the occasion of Athalaric's accession to the throne (9.9.3). A similar mission to Savia was ordered by Theoderic. All possessores were to be investigated and the equality of levy (aequalitas tributi) regulated so that the public tax (assis publicus) was imposed according to the category of properties and individuals, with each abatement that was made under others being revoked (5.14.2: $u t$ quae sub aliis facta est omni redemptione cassata pro possessionum atque hominum qualitate assis publicus imponatur). ${ }^{134}$ Payment and lawful levying of tax was a big concern for Theoderic's government, the more so since not only some were eager to avoid paying their dues, but some tended to arbitrarily levy taxes apparently for their own benefit. Therefore those who imposed taxation without the royal man-

\footnotetext{
${ }^{133}$ Cf. Biagio Saitta, “The Ostrogoths in Italy”, Polis. Revista de ideas y formas politicas de la Antigüedad Clásica 11 (1999): 202-204; with Meyer-Flügel, Das Bild, 499-501. On the taxation in Ostrogothic Italy, see Walter Goffart, "From Roman Taxation to Medieval Seigneurie: Three Notes", in: Idem, Rome's Fall and After (London; Ronceverte: The Hambledon Press, 1989), 168-177; John Hugo Wolfgang Gideon Liebeschuetz, "Barbarians and Taxes", in: Idem, East and West in Late Antiquity: Invasion, Settlement, Ethnogenesis and Conflicts of Religion (Leiden: Brill, 2015), 168-169.

${ }^{134}$ Cf. Walter Goffart, "Merovingian Polyptychs: Reflections on Two Recent Publications", in: Idem, Rome's Fall and After (London; Ronceverte: The Hambledon Press), 247-248.
} 
date and who, at their discretion, cast their burdens onto others were to be prosecuted with legal severity, and those to whom damage was done unauthorizedly were to be recompensed for every loss. The account of paid dues among the defensores, the curiales and the possessores was to be checked, and whatever a possessor would prove to have been imposed on him in excess of the tax money after the termination of the eighth indiction not long ago and was plain not to have been brought to the royal treasury, or would become clear by a correct account not to have been disbursed for necessary expenses made in the province, was to be corrected by every means as an unjust presumption (5.14.3: Eos autem, quos sine iussione nostra censum imposuisse constiterit et pro libito suo quorundam onera in alios proiecerunt, legum severitas insequatur, ut omnia illis detrimenta sarciant, quibus incompetenter damna fecerunt. Illud quoque praecipimus inquirendum, ut inter defensores, curiales et possessores illatorum ratio vestigetur et quicquid ab octava indictione nuper exempta super tributarium solidum se possessor probaverit intulisse nec nostro aerario constat illatum aut in expensis necessariis, quae in provincia factae sunt, iusta ratione non claruerit erogatum, iniqua praesumptio modis omnibus corrigatur).

Tax evasion sometimes tantamounted to a deliberate ignorance of regulations as is illustrated by the case of the antiqui barbari in Savia: "Old barbarians, who have chosen to join with Roman women in a marriage union and obtained estates under any title whatsoever, are to be compelled to pay the fiscal tax for landed property and to submit to extra levied liabilities" (5.14.6: Antiqui barbari, qui Romanis mulieribus elegerunt nuptiali foedere sociari, quolibet titulo praedia quaesiverunt, fiscum possessi cespitis persolvere ac superindicticiis oneribus parere cogantur). These barbarians - evidently the soldiers who used to be exempt from taxation due to their military status ${ }^{135}$ - seem to have tried to circumvent the obligations which resulted from new circumstances. The gravity of the situation affecting the fiscal revenue due from the province as well as offering opportunities for economic exploitation is shown by the fact that the letter addressed to the universi possessores of Savia explicitly says that the royal instructions have been made generally known: "Indeed, our published decree, which we gave to the aforementioned illustrious man Severinus, will anounce what we prescribe to be arranged for your relief and for the equality of taxes so that each one clearly knows that by which they may petition" (5.15.3: Qualia vero pro quiete vestra vel aequalitate tributorum disponenda censuimus, oracula nostra, quae dedimus ad supradictum virum illustrem Severinum, vulgata declarabunt, ut unusquisque unde supplicare debeat, evidenter agnoscat). ${ }^{136}$

\footnotetext{
${ }^{135} \mathrm{Cf}$. Amory, People and Identity, 53, note 31, 93. See also Lafferty, Law and Society, 226, who suggests that they claimed tax exemptions for recently acquired property.

${ }^{136}$ For cases of corruption with which Severinus had to deal in Savia, see also Helmut Castritius, "Korruption im ostgotischen Italien", in: Korruption im Altertum. Konstanzer Symposium Oktober 1979, ed. Wolfgang Schuller (München; Wien: R. Oldenbourg Verlag, 1982), 224-228.
} 
On the other hand, the situation in Dalmatia seems to have been much less pressing. To be sure, the Dalmatian taxpayers were also prone to misconduct. Thus it is reported of what can be construed as their fraudulent neglect to pay the siliquaticum: "Therefore, knowing the honesty of your mind through outstanding examples, our ordinance commits to you the tax of siliquaticum, which, by the right of dominion, we had given for a reliable revision for the first, second and third indictions in the province of Dalmatia, so that, as you investigate any trace whatsoever of fraud, a public loss would be discovered and is undoubtedly paid to our treasury, since we do not so much seek gain as hurry to come upon practices of the subjects" (3.25.1: Proinde sinceritatem animi tui per praeclara documenta noscentes siliquatici titulum, quem fidae dominicatus iure dederamus discussioni $i^{137}$ indictionis primae, secundae vel tertiae per provinciam Dalmaticam, ordinatio tibi nostra committit: ut quolibet fraudis vestigio damnum publicum te fuerit explorante repertum, procul dubio nostris aerariis inferatur: quia non tantum lucra quaerimus, quantum mores subiectorum deprehendere festinamus). The very fact that the siliquaticum, which was a tax on sales of all variety of commodities in the amount of 1 siliqua per solidus (1/24), was, or at least was attempted to be, farmed in Dalmatia, clearly indicates a developed commercial activity on local level and testifies to functioning of a still rather sofisticated fiscal administration. ${ }^{138}$ That the avoidance of paying the siliquaticum seems to have been a serious problem in Dalmatia in this particular instance is indicated by the fact that a special commissioner was sent to the province and the provincial comes was specifically instructed to lend assistance (3.26). ${ }^{139}$

Not all attention was directed towards taxation. The Variae also indicate that Dalmatia was interesting for its iron ore resources and that Theoderic's government

\footnotetext{
${ }^{137}$ I follow here Mommsen's emendation (p. 92). Based on the manuscripts, Fridh has titulum, quem fidae dominicatus iure dederamus, discussionem (p. 115), which is somewhat puzzling.

${ }^{138}$ On the siliquaticum, see Iohannes Karayannopulos, Das Finanzwesen des frübyzantinischen Staates (München: R. Oldenbourg, 1958), 149-150, 156; Jones, The Later Roman Empire, vol. 1, 205, 435, vol. 2, 826; with Dirk Henning, Periclitans res publica. Kaisertum und Eliten in der Krise des Weströmischen Reiches 454/5-493 n.Chr. (Stuttgart: Franz Steiner Verlag, 1999), 261; Nicholas Everett, "Lay documents and archives in early medieval Spain and Italy, c. 400-700", in: Documentary Culture and Laity in the Early Middle Ages, eds. Warren Brown, Marios Costambeys, Matthew Innes and Adam Kosto (Cambridge: Cambridge University Press, 2013), 74. However, certain exemptions had to be granted (cf. 4.19 regarding the sale of grain, wine and oil). The siliquaticum is referred to on several other places in the Variae $(2.4 ; 2.12 ; 2.26 .4 ; 2.30 .3 ; 5.31)$.

${ }^{139}$ Wozniak, "The Continuity of Roman Traditions", 379, has suggested that the siliquaticum was actually levied in the province, but was not delivered to Ravenna, because the Eastern Roman naval threat during the open hostilities between Constantinople and the Ostrogoths disrupted regular maritime communications between the two coast of the Adriatic as well as created disturbances in commercial activities. This is however not a likely explanation considering that Dalmatia and Italy were also connected by land. On the other hand, as Wozniak has also noted, perhaps the ongoing hostilities influenced the Ravenna government to ease somewhat the fiscal grip on the province for the time being, which in the end resulted in the need for a special commisioner to be sent and see to it that the tax obligations were met.
} 
took steps to instill new life into local mining industry. ${ }^{140}$ The mining for gold, silver, copper, lead and iron was rather well-developed in Dalmatia in early Roman imperial times (the first to third centuries), and it has been inferred that the search for some of these metals was revived in the province during the Ostrogothic rule. ${ }^{141}$ The iron mining was particularly strong in the Japra, Sana and Una Rivers regions (modern northwestern Bosnia and Herzegovina), and it may perhaps be presumed that Ostrogothic efforts primarily targeted that area. ${ }^{142}$ Archaeological research has established that an iron processing facility at Blagaj Japra near the modern town of Bosanski Novi flourished under Justinian I's rule. In the facility's immediate neighborhood, a settlement sprang up with villas, where the facility managing staff lived with their families, while miners and smelters probably had to settle with a farther vicinity. A large basilica was also erected on top of earlier housing buildings. ${ }^{143}$ It is surely not far-fetched to conclude that this Justinianic revival was based on the previous measures taken by the Ostrogothic government.

Another source of revenue for the central government were the royal estates. The mention of vicedomini indicates that they existed in Savia (5.14.8), and surely in Dalmatia and Pannonia Sirmiensis as well. Such an estate must have been the Polače bay palace complex with appurtenant land property on the island of Mljet. ${ }^{144}$ The estate once belonged to Odoacer's comes domesticorum Pierius and it certainly passed to Theoderic's patrimony after he had established his rule over Italy. Odoacer's deed of donation to Pierius from March 489 shows that the estate yielded a yearly income of 200 solidi from agricultural production and possibly from commercial tax since a portorium is believed to have been set up on the island, and it continued to do so, considering that a testament from the

\footnotetext{
${ }^{140}$ Cf. Wozniak, "East Rome", 375; Idem, “The Continuity of Roman Traditions", 380. The interest of the Ostrogothic government for acquiring precious metals is attested elsewhere in the Variae $(4.34 ; 9.3)$. See also Meyer-Flügel, Das Bild, 234-237.

${ }^{141}$ Ante Škegro, “Bergbau der Römischen Provinz Dalmatien”, Povijesni prilozi 17 (1998): 31-88, esp. 42 (gold), 88 (iron).

${ }^{142}$ Cf. Škegro, "Bergbau", 74-75 (the Japra region), 77 (the Sana region), 82-83 (the Una region); with Đuro Basler, Spätantike und frühchristliche Architektur in Bosnien und der Herzegowina, revised by Renate Pillinger, Andreas Pülz and Hermann Vetters (Wien: Verlag der Österreichischen Akademie der Wissenschaften, 1993), 16.

${ }^{143}$ Basler, Spätantike und frühchristliche Architektur, 18, 44-45; with Idem, "Naselje uz metalurški pogon u dolini rijeke Japre" [A Settlement next to the Metallurgical Facility in the Japra River Valley], in: Materijali XIII, Simpozijum Antički gradovi i naselja u južnoj Panoniji i graničnim područjima, Varaždin 1975, ed. Branka Vikić-Belančić (Beograd: Savez arheoloških društava Jugoslavije, 1977), 137-146.

${ }^{144}$ For the complex, see the literature cited in Gračanin, "The history of the eastern Adriatic region", 70, note 22. For the evidence related to imperial estates in Dalmatia, some of which were later transferred to the Ostrogothic king, cf. Tin Turković, "The Late Antique 'Palace' in Polače Bay (Mljet) - Tetrarchic 'Palace'?", Hortus Artium Medievalium 17 (2011): 213-215, 223, 227 (note 6), 229 (note 37 and 38), 233 (notes 111 and 112).
} 
mid-sixth century attest to the equal amount of money received per year from private holdings on the Mljet. ${ }^{145}$

Apart from occasional relaxing of the fiscal grip, the Ostrogothic government seems to have been prepared to directly help the provincial tottering finances. ${ }^{146}$ Theoderic is likely to have subsidized the provincial administration in Savia, but the money was apparently embezzled. The royal indignation at the funds not being spent for its rightful purpose clearly echoes in the letter: "For is it not absurd that our generosity, which we want to profit everyone, has now been suppresed by few in stolen gain?" (5.14.4: Quid enim tam absurdum, nisi ut liberalitas nostra, quam universis proficere volumus, nunc a paucis furtivo compendio opprimatur?). Another way to help the provincial economy was to spur the local commercial exchange. The contingent of Gepids travelling from Pannonia Sirmiensis to Gaul were secured rations in kind (annonae) along their march route (5.11), but they were also provided with a substantial sum of money to purchase the necessary provisions at markets organized at their stops along the way $(5.10 .3 ; 5.11) .{ }^{147}$ Even though the letter makes this allocation effective only for the Gepids' march through northern Italy, they may have also been disbursed some cost money for their passage through Savia and southern Noricum, if it may be presumed that Theoderic was inclined to show the same considerations for the inhabitants of Savia and southern Noricum as for the inhabitants of Venetia and Liguria.

The Variae also indirectly indicate to one aspect of the regional agricultural production, the livestock breeding. The letters mention the cattle rustlers in Savia (4.49) as well as animals of the ambulatory Gepids (5.10.3), presumably both oxen and horses. To be sure, what is said about Histria regarding the production of wine, olive oil and grain $(12.22 .1 ; 12.23 .1 ; 12.24 .1)$ and about the lagoonal area of Venetia regarding the fish consumption and salt-works (12.24.5-6) may be taken as equally valid for Dalmatia, especially when bearing in mind that the mention of islands appended to the coast of Histria, which are said to enrich the farmers by great fertility, most probably refers to the islands in modern Kvarner Bay region (12.22.5). ${ }^{148}$ Perhaps this agricultural fertility as well as the islands'

\footnotetext{
${ }^{145}$ Cf. Ivanka Nikolajević, "Veliki posed u Dalmaciji u V i VI veku u svetlosti arheoloških nalaza" [The Large Estate in Dalmatia in the 5th and 6th Centuries in the Light of Archaeological Finds], Zbornik radova Vizantološkog instituta 13 (1971): 280-282, 285-288; Turković, “The Late Antique 'Palace”, 214.

${ }^{146}$ Wozniak, "The Continuity of Roman Traditions", 378, has inferred that Teoderic may have also paid the costs of the province of Dalmatia out of the patrimonial treasury.

${ }^{147}$ Cf. Goffart, "From Roman Taxation", 178.

${ }^{148}$ On the production of wine and olive oil in late antique Histria and Dalmatia, see Jana Kopáčková, "Production of Wine and Olive Oil in Roman Histria and Dalmatia in Late Antiquity", Studia Hercynia 18 (2014), nos. 1-2: 75-88; with Robert Matijašić, "Oil and wine production in Istria and Dalmatia in classical antiquity and the early middle ages", in: La production du vin et de l'huile en Mediterranée - Oil and Wine Production in the Mediteranean Area. Actes du symposium international organisé par le Centre Camille Julian et le Centre archéologique du Var, Aix en Provence et Toulon, 20-22 novembre 1991, eds. Marie-Claire Amouretti and Jean-Pierre Brun (Paris: École Française d'Athènes; De Boccard, 1993),
} 
size and convenient position was what prompted the Ravenna government to appoint a special comes in charge of Krk and Cres. Much more greater resources of coastal and insular Dalmatia must have surely attracted commercial enterprises from across the Adriatic, such as suggested for the Venetian tribuni maritimorum. ${ }^{149}$ Finally, one incidental piece of information may be taken as equally relating to Pannonia Sirmiensis. The letter addressed to a fiscal official (canonicarius) of Venetiae mentions, among delicacies for the royal table, carp as being sent by the Danube (destinet carpam Danubius; 12.4.1). Even though it is fairly certain that the fish came from the waters of the Upper Danube in Raetia considering the province's immediate proximity to Italy, the southern Pannonian part of the Danube was undoubtedly also fished for carp and it may be assumed that river fishing was a developed local economic activity. ${ }^{150}$

\section{Provincial society}

The Variae provide testimony for the structure and functioning of post-Roman provincial society in Dalmatia and southern Pannonia. ${ }^{151}$ The central place is afforded to the middle class, which is even directly referred to as a social group: mediocres (5.14.1). ${ }^{152}$ Neither the highest-ranking social category of primates, praepotentes or honorati nor the lower class of humiles are mentioned as such, let

247-261; Idem, "Sredozemno prehrambeno trojstvo u antici na Jadranu [Mediterranean nutritional trinity in the ancient period in the Adriatic]", in: Cerealia, oleum, vinum... Kultura prehrane i blagovanja na jadranskom prostoru, 3. Istarski povijesni biennale. Zbornik radova s međunarodnog znanstvenog sku$p a$, vol. 3, eds. Marija Mogorović Crljenko and Elena Uljančić-Vekić (Poreč: Zavičajni muzej Poreštine; Državni arhiv u Pazinu; Sveučilište Jurja Dobrile - Odjel za humanističke znanosti, 2009), 37-54; and papers by Robert Matijašić, Marin Zaninović and Kristina Glicksman from the proceedings of the International archaeological symposium Viticulture and olive growing from Prehistory to the Middle Ages published in Histria Antiqua 15 (2007). On the production of salt on the eastern Adriatic in antiquity, see Marin Zaninović, "Sol u antici naše obale" [Salt in Antiquity of Our Coast], in: Zbornik radova posvećenih akademiku Alojzu Bencu, ed. Borivoj Čović (Sarajevo: Akademija nauka i umjetnosti Bosne i Hercegovine, 1991), 255-264. Suić, Zadar u starom vijeku, 320, has suggested that the salt production in the region of Zadar may have been revived in the Ostrogothic period.

${ }^{149} \mathrm{~A}$ perspective from other coast side of the Adriatic is once offered by Cassiodorus (12.22.3), and he only three times mentions the Adriatic Sea (12.15.1: sinus Hadriaticus; 12.22.3: sinus mari Ionii; 12.24.3: litora Ionii).

${ }^{150} \mathrm{Cf}$. also Lotter, Völkerverschiebungen, 129, with Bratož, Med Italijo in Ilirikom, 386, note 62. It is interesting to note that carp is usually believed to have started inhabiting the Upper Danube waters only by the late eleventh century. Richard C. Hoffmann, "Carp, Cods, Connections: New Fisheries in the Medieval European Economy and Environment", in: Animals in Human Histories. The Mirror of Nature and Culture, ed. Mary J. Henninger-Voss (Rochester: University of Rochester Press, 2002), 9-10.

${ }^{151}$ Instructive for this chapter is Ghislaine Noyé, "Social Relations in Southern Italy", in: The Ostrogoths from the Migration Period to the Sixth Century: An Ethnographic Perspective, eds. Sam J. Barnish and Federico Marazzi (Woodbridge: Boydell Press, 2007), 183-202.

${ }^{152}$ One other example relates to Histria (12.22.5), where a brief reference about the primates is also made. 
alone the unfree population. ${ }^{153}$ The class of mediocres is identified in the Variae with possessores, which refers to their legal and, even more, fiscal-financial status. They are explicitly mentioned only with regard to Savia (5.14.1; 5.14.2; 5.14.3; 5.14.5; 5.15 titulum), and twice implied with regard to Dalmatia (4.9; 5.24). The provincial middle- and low-ranking officials as well as the defensores and curiales might also be considered as mediocres. However, since the terms defensores and curiales chiefly denote functions within the municipal administration, they could belong to the province-based honorati, much like the possessores could, in the broad sense, denote the honorati who were the landholder elite and even the Goths who owned landed property and were obliged to pay tax. ${ }^{154}$ To the honorati, high-ranking officials currently on duty in the provinces, military and civil governors, also counted by necessity. ${ }^{155}$ The people on the lower rungs of society are both explicitly called the poor (pauperes; 5.14 .7 ) and referred to as those whom the poverty might hurl to their deaths since they are apparently not able to pay the court fees and thus resort to customs unbecoming a civilized society such as resolving lawsuits by duels (3.23.4). Albeit this is not explicitly stated, a special status was enjoyed by soldiers and groups such as the capillati and antiqui barbari. Apart from government officials, all these various groups of people residing in the province, regardless of their social rank and financial status, were, from the perspective of the Ravenna government, covered by the term provinciales, which is mostly used in relation to Savia and on one occasion rendered as nostri provinciales (4.49 titulum; 5.14.1; 5.14.2; 5.14.7; 5.14.8; 5.14.9), and only once in relation to Dalmatia (8.12.3).

Whether the social groups are explicitly mentioned or just implied, the Variae reveal that the basic makeup of the provincial society was a well differentiated and diverse one, which is especially valid for southern Pannonia. What is more, it is clear that the urban communities functioned along the lines of late Roman system with city councils and municipal magistrates. The possessores were accorded an important place inasmuch as their main social and political role was to pay taxes and thus secure supply and pay for the army and government officials. ${ }^{156}$ The picture of the social living conditions in southern Pannonian provinces that is painted by the Variae is generally rather gloomy. This can be particularly said

\footnotetext{
${ }^{153}$ On these groups within the Variae, see Meyer-Flügel, Das Bild, 217-229, 250-266, 319-373, 510-517, 547-553, 558-559.

${ }^{154}$ See also Giovanni A. Cecconi, "Honorati, possessores, curiales: competenze istituzionali e gerarchie di rango della città tardoantica", in: Le trasformazioni delle élites in età tardoantica. Atti del convegno internazionale, Perugia, 15-16 marzo 2004, ed. Rita Lizzi Testa (Roma: L'Erma di Bretschneider, 2006), 41-60. The Variae indicate that the Goths also had to pay tax $(1.19 ; 4.14)$; with Mommsen, "Ostgotische Studien", 438, note 1; Burns, A History of the Ostrogoths, 128; Meyer-Flügel, Das Bild, 121.

${ }^{155}$ Schäfer, Der weströmische Senat, 137-138, believes both Arator and Severinus to have had possessions in Dalmatia and Savia respectively, which would also make them members of the provincial honorati.

${ }^{156} \mathrm{Cf}$. Amory, People and Identity, 53.
} 
of Savia and, to some extent, of Pannonia Sirmiensis, whereas Dalmatia seems to have enjoyed much better stability. Such darkly painted image of social circumstances may perhaps be misleading, since the Variae often refer to all sorts of irregularities and criminal acts. Nevertheless, the reported amount and repetition of negative occurrences within the provincial society could be taken as quite indicative of rather unfortunate state of everyday affairs. ${ }^{157}$ As already mentioned, Savia seems to have been fraught with all kinds of problems with criminality, misuses of power and position, and failure to comply to civic duties. Judging by what the Variae say, the province was plagued with cases of murders, thefts, cattle rustling ${ }^{158}$, tax evasion, abuses by provincial officials, municipal officers and the military against the possessores, and abuses by prosperous landowners against the common population $(4.49 ; 5.14)$. It would be tempting to propose that a comes Gothorum from 5.14.8, who is likely to have been based at Siscia and in charge of the entire province of Savia, was actually subsequently introduced as a permanent officer due to the problems which the province experienced with law and order (Fridibadus may have been first such comes). After merging of the provinces of Dalmatia and Savia, which meant that a separate comitiva provinciae for Savia was dissolved, the provincial comes based at Salona seems not to have been able to control effectively the circumstances in northernmost parts of his jurisdictional area and this perhaps prompted a decision to appoint another local Gothic high official with military and civil authority. Considering that when comes Severinus was sent to Savia more than a decade later the pressing problems seem not to have been murders, thefts and cattle rustling any longer (or at least they are not mentioned or alluded to in the letter as such), it may be presumed that the move by the Ravenna government to appoint a special Gothic officer in charge of Savia proved to be successful in this respect. As for Pannonia Sirmiensis, apart from thefts and presumably cattle rustling (the latter is however not explicitly mentioned), the most grievous problems seem to have been the conflicts between the barbarian and Roman populations and the practice of settling disputes and quarrels outside the court of law by engaging into duels. This practice is likely to have arisen during the decades when there was no central government control nor any provincial

\footnotetext{
${ }^{157}$ Wozniak, "East Rome", 375-376, speaks of animosities between the Roman majority and the Gothic civil-military administration. However, that what can be deduced from the letters rather points to a conclusion that the problem lied not so much with the Gothic administration as with the provincials themselves, even though the representatives of the Ostrogothic authorities had also had their share in the variety of abuses.

${ }^{158}$ It is perhaps interesting to note that Jordanes, Getica 273-274, describes how the Suevi under their king Hunimund seized, on their way to Dalmatia, some cattle that freely roamed the fields, and actually belonged to the Ostrogothic king Thiudimir. There is certainly no direct connection between Jordanes and Cassiodorus on this point, but if the Suevi, as is believed, constituted a large group of the inhabitants of Savia, they are likely to also have been among local cattle rustlers. Based on what the Variae have to say, cattle rustling seems to have been practically endemic to southern Pannonia, since this criminal activity is reported only for Savia in the entire collection. Nevertheless, the fight against the abactores is cited as one of the main tasks of comes provinciae in the formula for his appointment (7.1.3).
} 
administration attested in the area. Its spread is evident from two letters. One is addressed to the Ostrogothic governor: "Foster equity, defend innocence by virtue of mind, so that, among the perverted custom of the peoples, you may display the justice of the Goths who have always been placed within reach of praiseworthiness so that they would both capture the wisdom of the Romans and possess the virtue of the tribes. Do away with the detestable practices that have grown: let lawsuits thereupon be conducted rather by words, not by swords; let not losing a case be combined with death; let he who withholds another's property repay the theft, not his life; let not civil litigation rob more than wars destroy; let shields be raised against enemies, not the kindred" (3.23.3: Aequitatem fove, innocentiam animi virtute defende, ut inter nationum consuetudinem perversam Gothorum possis demonstrare iustitiam: qui sic semper fuerunt in laudum medio constituti, ut et Romanorum prudentiam caperent et virtutem gentium possiderent. Remove consuetudines abominanter inolitas: verbis ibi potius, non armis causa tractetur: non sit coniunctum negotium perdere cum perire: abiurator alieni furtum, non animam reddat: ne plus intentio civilis rapiat quam bella consumant: scuta in hostes erigant, non parentes). The other letter is addressed to the barbarians and Romans residing in the province: "We moreover trust you to have to be admonished of this, so that you would desire to rage not against yourselves, but against the enemy. Let not small matters lead you into extreme perils; find relief in justice, in which the world delights. Why do you resort to duels when you have an incorruptible judge? Lay aside the sword when you do not have an enemy. You most wickedly raise the hand against the kindred, for whom is worth to die. What use is the tongue to a human if an armed hand conducts a lawsuit? Or how one believes the peace is possible if one fights under civil condition?" (3.24.3-4: Illud praeterea vos credidimus ammonendos, ut non in vos, sed in hostem saevire cupiatis. Res parva non vos ducat ad extrema discrimina: adquiescite iustitiae, qua mundus laetatur. Cur ad monomachiam recurratis, qui venalem iudicem non habetis? Deponite ferrum, qui non habetis inimicum. Pessime contra parentes erigitis brachium, pro quibus constat gloriose moriendum. Quid opus est homini lingua, si causam manus agat armata? Aut pax esse unde creditur, si sub civilitate pugnetur?). For Dalmatia, on the other hand, there is only mention of two cases in which the possessores tried to illegally or dishonestly obtain property $(4.9 ; 5.24)$ and not a single indication of problems that confronted southern Pannonia. These problems may be seen as indicative of much poorer economic conditions with which Savia and Pannonia Sirmiensis had to struggle, something the Ravenna government appears to have tried to alleviate (money allocated to Savia, 5.4; the governor of Pannonia Sirmiensis exhorted to pay for persons who could not afford to settle the costs of judicial proceedings themselves, 3.23.4).

If the conflicts between the barbarians and Romans were reality of life in the frontier society of Pannonia Sirmiensis, which might be taken as to have had 
relevance for Savia as well, considering that the province seems to have contained a large barbarian population, there exist an example of the social integration between the Roman population and the barbarians. The antiqui barbari of Savia are reported to have taken Roman women as wives and seem to have begun living like possessores (5.14.6). The Romans of southern Pannonia had much more experience with living next to their barbarian neighbors, the Goths included, which obviously could both cause troubles and serve as a basis for a more harmonious relationship. The Variae reveal the effort that the Ostrogothic government took to maintain order and security within the provinces. This sometimes entailed mixing the blandishments with reproaches, as in the already mentioned letter directed to the provincial population of Pannonia Sirmiensis. They are urged to show now the governor, too, their "often proven obedience," and are seemingly promoted into a sort of a controlling position over him, since the continuation of the sentence says as follows: "inasmuch as he should command reasonably in that which is to be done to the benefit of our kingdom and should be completed with commendable dedication, for constancy proves the trustworthiness and he who persists in continuous service affirms the integrity of his own mind" (3.24.2: Atque ideo parientiam vestram saepius approbatam nunc quoque eidem praesenti monstrate, quatenus in his quae pro regni nostri utilitate rationabiliter agenda praeceperit, devotione probabili compleantur: quia fidem constantia probat et ille integritatem propriae asserit mentis, qui iugibus persistit obsequiis). Such blandishments are perhaps best understood in the context of a far-off frontier province that, nonetheless, carried a special importance for the Ravenna government.

What may be worth considering is the mechanism by which royal government acted to secure orderly state of affairs in the provinces and protect the interests of various social groups and, by extension, its own interest. The case of Savia is instructive, since the three related letters testify that the effort spanned over more than two decades and was aimed at different social, office-holding and professional groups. The first instance in which these groups in Savia figure as those towards whom the king's action is directed is the appointment of Fridibadus to take charge of the province (4.49). The letter is addressed to all provincials, the capillati, the defensores and the curiales. The two opening sentences of the letter refer to the king's wish that Fridibadus' mission be publicized as this might serve as a deterrent: "The investigation by royal command never ought to be withheld so that both fear would press the audacious and hope for the future would again comfort the abused. For an announced threat usually accomplishes more than what a punishment settles" (Districtio semper subtrahi non debet regiae iussionis, ut et audaces metus comprimat et laceratos spes futura refoveat. Plerumque enim denuntiata comminatio plus efficit quam poena componit). Nothing is said about whether the royal action was prompted by an appeal from the provincials themselves, but this is likely. It may be assumed that all landowning groups 
were interested in eradication of grave crimes such as murders and thefts. The defensores and curiales were presumably expected to directly lend a hand to Fridibadus in an attempt to suppress wrongdoings in the province by making sure that his investigation is generally known to the provincial population. Much more specific is the second letter, addressed to Severinus, which lists various offences but, as already noted, apparently none of those that plagued Savia before (5.15). The letter explicitly states that the king was spured to action by a repeated complaint from the provincials who had been abused by well-off landowners (possessores idonei) using their position of economic power and political influence on local level to transfer their fiscal obligations to the less fortunate (tenuis fortuna) (5.15.1). It is clear that Severinus' investigation was directed against the upper strata of provincial society which are, in this particular case, distinguished from the provinciales. However, the third letter informing the interested parties of Severinus' mandate is addressed to all landowners, that is to say, both the betteroff and less-off (5.15). ${ }^{159}$ This letter is more detailed when referring to Theoderic's being apprised of the landowners' problems: the king was frequently approached (frequens aditio) by provincial representatives who are not explicitly mentioned but alluded to as weary of a long travel (fatigatio longi itineris), learned with clever dutifulness (ingeniosa pietas) what the grievance was and decided to alleviate the landowner's troubles by granting them the aequitas. A querela that is mentioned relates to a tax burden in general, which was a common complaint by provincials in all times. Those who are heavy burdened are called to declare their tax load without any fear of a stranger (Severinus as the official investigator is meant), and to accept the remedy that they should have from the laws (5.15.3: sine aliqua formidine alieni tributi sarcina gravatus exclamet, accepturus remedium quod de legibus habet). The expressed intention of the royal government is to establish the equality of taxes (aequalitas tributorum), which is something that concerns all landowners. What may be concluded from the second and third letters is that the representatives of the provincial mediocres made a direct appeal to the king about both a burden of due taxes and the abuses to which they had been exposed by more wealthy and influential landowners. The royal action is presented as manifold and was aimed at preventing various kinds of abuses within the provincial society, the inter- and intra-class abuses as well as the abuses of office holders and professionals against the provincials in general, and at seeing to it that all taxpayers comply to their fiscal obligations according to the regulations

\footnotetext{
${ }^{159}$ An exclusive address to possessors is very rare in the Variae and occurs only four times in total (3.44; $5.9 ; 5.15 ; 5.38)$. The possessores as addressees are mentioned in several other cases, always after the honorati and before the defensores and curiales $(2.17 ; 3.9 ; 3.49 ; 4.8 ; 6.24 ; 7.27 ; 8.29 ; 9.10)$, which shows their importance as a group within the Ostrogothic system of government. Apart from two examples, the one related to Savia (5.15) and another to Gaul (3.44), all others are linked to Italy (the address in 5.38 merely has universis possessoribus without adding a town or a region, but it is clear from the letter itself that the area of Ravenna is meant).
} 
and their economic strength. What is more, the second letter clearly indicates that in the first half of the sixth century there existed a landholder elite in Savia, which perhaps could not be compared with the honorati of Italy, but was nevertheless a power to reckon with on local level. The possessores of Dalmatia are also shown as beneficiaries of the royal care and generosity concerning the taxation, which is a testimony to their influence as a group: Athalaric's government remits the surtax augmentum and promises to investigate into the tax load and if the provincials are found to be heavy burdened, they may expect to receive a relief with mindful equity (considerata aequitas) (9.9.3-4). The Dalmatian landowners could also afford to enlist help from influential persons at the court, such as comes domesticorum Arator. It may be assumed that his embassy on behalf of the provincials in Dalmatia was instrumental in prompting this indulgent royal attitude, while the necessitates provincialium about which he spoke so eloquently before Theoderic very likely referred first and foremost to a tax burden (8.21.3). All these examples show not only that there existed a vested interest of the royal government in the provincial circumstances, but also that the politically and economically leading provincial strata of Dalmatia and Pannonia could directly prompt action from the king. Furthermore, they show that there still existed power struggles within local communities of which the Ravenna authorities were made aware and in which they interceded.

\section{Provincial ethnic picture}

One of the important features of the Variae as an historical source is that they furnish a contemporary evidence, both explicit and implicit, for the existence of various ethnic identity groups in Dalmatia and Pannonia under the Ostrogothic rule during the first three decades of the sixth century. ${ }^{160}$ Ordered by provinces, these groups are as follows:

- in Dalmatia:

Gothi (8.4.2; 9.9 titulum);

Romani (8.4 titulum; 8.4.2; 9.9 titulum);

- in Pannonia Sirmiensis:

barbari (3.24 titulum; 8.21.3: gentilis Danubius);

\footnotetext{
${ }^{160}$ Of other contemporary sources worth mentioning, Procopius, Bellum Gothicum, speaks of the Romans in Salona (1.7.10); the Goths settled in Dalmatia and Liburnia (1.7.36); the Siscians and the Suevi inhabiting the interior north of Liburnia, Istria and Venetia; the Pannonians extending to the Danube (1.15.27); and the barbarians in Suavia (1.16.9). Otherwise only Menander Protector, Historia fr. 5.4, 2-6, in The History of Menander the Guardsman, introductory essay, text, translation and historiographical notes by Roger C. Blockley, Liverpool: Francis Cairns, 1985, mentions the land of the Heruls in Pannonia Secunda, where the Heruls once dwelled. The Heruls are referred to twice in the Variae (3.3 titulum; 4.2 titulum; 4.2.3), but on both occasion those still living in their earlier abode along the Middle Danube to the north of the former Roman Pannonia (cf. Lotter, Die Völkerverschiebungen, 130).
} 
Gepidi (5.10.2; 5.11 titulum) ${ }^{161}$;

Gothi (3.23.3: Gothorum iustitia $\left.{ }^{162} ; 3.24 .4\right)$;

Romani (3.24. titulum);

- in Savia:

barbari (5.14.6: antiqui barbari);

Gothi (5.14.8: domestici comitis Gothorum; 9.9 titulum);

Romani (5.14.6: mulieres Romanae; 5.14.7: iudex Romanus; 9.9 titulum).

What immediately sticks out is the absence of the category barbari in Dalmatia. This may be interpreted as meaning that there were no other groups except the Goths that could, from the Roman perspective, be designated as barbarians; that there were other barbarians, but they were all concealed under the Gothic label; or that the number of barbarians living in the province was so insignificant that it did not deserve any mention. One further possibility, namely that the barbarians were simply not referred to, even though they were not so small a community in Dalmatia, seems unlikely in this particular case. Dalmatia is never mentioned in sources as settled by barbarian groups. The Ostrogoths were indeed resettling and admitting barbarian groups into their territory very much like the Romans $\operatorname{did}^{163}$, but there is no indication that Dalmatia was ever influenced by these processes. To be sure, there is some material evidence that has been interpreted as indicating the presence of Gepids in Dalmatia, but this is far from certain, not the least because the method of interpretation which has been used clings to the outdated culture-history paradigm that archaeological cultures reflect specific ethnic groups of the past. ${ }^{164}$ Nevertheless, it cannot be entirely excluded that there were non-Gothic groups present in the province as soldiers in the Ostrogothic service and that they were concealed under the Gothic label. In Theoderic's eyes, Goths equal soldiers and, consequently, anyone who was a part of the exercitus Gothorum could be seen as Gothic, regardless of their distinct ethnic identity. ${ }^{165}$ Speak-

\footnotetext{
${ }^{161}$ They are not explicitly referred to in the Variae as living in Pannonia Sirmiensis.

${ }^{162}$ The phrase can otherwise be understood in quite general terms, but in the context of the mandate given to the comes Colosseus it could be also seen as referring to the justice of Goths already residing in the province.

${ }^{163}$ For instance, the Alamanni were admitted to the Ostrogothic Kingdom as the Variae indicate (3.50; 12.28.4).

${ }^{164}$ Cf. Ante Uglešić, "Nalaz fibule seobe naroda iz Brguda kod Benkovca" [A Migration-Period Find from Brgud near Benkovac], Archaeologica Adriatica 3 (2009): 185-187.

${ }^{165} \mathrm{Cf}$. Amory, People and Identity, 53, 51-152, 114, 319-320. This may be particularly applied to the Gepids who were thought to be a branch of the Goths (cf. Jordanes, Getica 94-95; with Amory, People and Identity, 190). On the question of Gothic identity, see also Peter Heather, "Merely and Ideology? - Gothic Indentity in Ostrogothic Italy", in: The Ostrogoths from the Migration Period to the Sixth Century: An Ethnographic Perspective, eds. Sam J. Barnish and Federico Marazzi (Woodbridge: Boydell Press, 2007), 31-60.
} 
ing in ethnic identity terms, the Salonitani milites (1.40), meaning Gothic soldiers that were stationed in Salona, could thus have really been only Ostrogoths, that is to say, the Goths who derived their identity from acknowledging Theoderic's clan as their ruling clan, but they could also have been composed of Goths, Gepids and perhaps members of other gentes whom the Ostrogoths incorporated into their ranks. They could be all perceived as Goths due to their professional status, and at the same time retain their distinct ethnic identities with their own customs and style preferences that could identify them as separate groups. The Gepids of Pannonia Sirmiensis preserved their separate identity, and the Ravenna government recognized this fact. The multitudo Gepidarum that is sent to Gaul as a protective force seems not to have been perceived just as an exercitus (5.10.1), even though this was their primary purpose. ${ }^{166}$ The word multitudo refers both to quantity and quality, i. e. the number and the composition. What this means is that Theoderic ordered the relocation of a large group of Gepids, men, women and children alike, from southern Pannonia to their new abodes in Gaul. This seems to be supported by the usage of the term condama $(5.10 .2 ; 5.11)$ which means a household or family, a unit receiving rations. ${ }^{167}$ Perhaps that is why three solidi were accorded, which otherwise might appear a rather large sum of money. ${ }^{168}$

As opposed to Dalmatia, Savia and Pannonia Sirmiensis are shown to have been inhabited by groups of barbarians. The antiqui barbari, as they are styled in the Variae, are a somewhat enigmatic group, much like the capillati. As have been noted earlier, in the context of what the Variae remark, the soldiers are probably meant. However, this does not necessarily mean that all these barbarians were soldiers. ${ }^{169}$ The term itself seems to refer to their antiquity, that is to say, the antiqui barbari were residents of old in Savia. ${ }^{170}$ They are usually thought not to be

\footnotetext{
${ }^{166}$ Amory, People and Identity, 94, believes them to be only soldiers and suggests that they might have had status of a named regiment or of foederati within the army.

${ }^{167}$ Gillet, "From Roman Taxation", 178-179; with Wilhelm Ensslin, "Aus Theoderichs Kanzlei", Würzburger Jahrbücher für Altertumswissenschaften 2 (1947): 84-85; Constantin C. Diculescu, Die Gepiden. Forschungen zur Geschichte Daziens im frühen Mittelalter und zur Vorgeschichte des rumänischen Volkes, vol. 1 (Leipzig: C. Kabitzsch, 1923), 118. Matthias Hardt, Gold und Herrschaft. Die Schätze europäischer Könige und Fürsten im ersten Jahrtausend (Berlin: Akademie Verlag, 2004), 248, calls the condamae small subdivisions of a large crowd of Gepids, but these were not ad hoc units.

${ }^{168} \mathrm{Cf}$. Hodgkin, The Letters, 271, who somewhat misunderstood the pertinent passages of the text.

${ }^{169}$ Implied by Amory, People and Identity, 53, note 31, 93, 162. It is worth noting that Amory understands antiqui barbari as "former barbarians" (p. 53, note 31; p. 93, note 34), and refers to Mommsen in regard to that, but Mommsen only says that these barbarians forfeited their right to be tax exempt by marrying Roman women ("Ostgotische Studien", 440-441, note 4, 475, note 3). Surely, what the letter says is not that the antiqui barbari had ceased to be barbarians, i.e. soldiers, but merely that they now had to pay the land tax as other possessores.

${ }^{170}$ Cf. Jaroslav Šašel, “Antiqui Barbari. Zur Besiedlungsgeschichte Ostnoricums und Pannoniens im 5. und 6. Jahrhundert nach den Schriftquellen", in: Von der Spätantike zum frühen Mittelalter. Aktuelle Probleme in historischer und archäologischer Sicht, eds. Joachim Werner and Eugen Ewig (Sigmaringen: Jan Thorbecke, 1979), 135; Wolfram, Die Goten, 301, 320; Lotter, Völkerverschiebungen, 37. Also implied by Helmut Castritius, "Barbari - antiqui barbari. Zur Besiedlungsgeschichte Südostnoricums und
} 
the Goths, but the opinion is not unanimous, even though the recent scholarship tends to identify them with the Suevi of Savia. ${ }^{171}$ Similarly, the barbari of Pannonia Sirmiensis are believed to mostly refer to the Gepids, ${ }^{172}$ which is probably a certain identification in the case of the phrase gentilis Danubius from 8.21.3, since it obliquely relates to the Ostrogothic conquest of Gepidic kingdom based at Sirmium. It may be indeed assumed that under the antiqui barbari of Savia and the barbari of Pannonia Sirmiensis the Suevi and the Gepids, respectively, are meant. However, it is equally conceivable that any other barbarian group living in southern Pannonia might be included. For instance, the Alamanni who are believed to have been introduced into southern Pannonia after the collapse of their kingdom, swelling the number of Suevi in Savia. ${ }^{173}$ Or perhaps even the Sarmatians who are known from the written sources to have attacked Theoderic's Goths somewhere in modern Syrmia in $489 .{ }^{174}$ One is nevertheless clear: from Theoderic's point of view, channeled through Cassiodorus, the most important thing about all of these barbarians was that they were neither Goths nor Romans.

\section{Politics and ideology}

At closer look, regardless of the evidence's fragmentary nature, the Variae provide a peak into what may be called an Ostrogothic policy towards the region as well as offer elements of the ideology represented and conveyed by the Ravenna

Südpannoniens in der Spätantike (Ende des 4. bis Mitte des 6. Jahrhunderts n. Chr.)", Frühmittelalterliche Studien 29 (1995): 77-79, 83.

${ }^{171}$ Castritius, "Barbari - antiqui barbari", 79-84; Lotter, Völkerverschiebungen, 123-126. See also Gračanin and Škrgulja, "The Ostrogoths", 184. For instance, Moorhead, Theoderic, 85, thinks that they were not Goths, whereas Lafferty, Law and Society, 226, believes them for Goths. The older scholarship referred to them as non-Roman (see Mommsen, "Ostgotische Studien", 440; Schmidt, "Die comites Gothorum", 127-128, note 2).

${ }^{172}$ Cf. Gračanin and Škrgulja, "The Ostrogoths", 184, with note 105.

${ }^{173}$ Cf. Castritius, "Barbari - antiqui barbari", 106; Lotter, Die Völkerverschiebungen, 125-126; Wolfram, Die Goten, 317; with Gračanin and Škrgulja, "The Ostrogoths", 185. The Variae record the overthrow of the Alamannic kingdom $(2.41 ; 12.28 .4)$ and their move through Noricum, where the provincials are allowed to engage into barter with passing Alamannic groups (3.50), and on one occasion refer to an incursion of the Suevi into Venetiae (12.6.1). It has even been inferred that some archaeological finds from the necropolis at the Bošnjića Voće site south of Rakovčani near Prijedor in northwestern Bosnia and Herzegovina (the border area between Savia and Dalmatia) indicate the presence of Alamanni. Cf. Zdenko Vinski, "Rani srednji vijek u Jugoslaviji od 400. do 800. godine" [The Early Middle Ages in Jugoslavia from 400 to 800 AD], Vjesnik Arheološkog muzeja u Zagrebu 3rd ser., 5 (1971): 54; Vladimir Sokol, "Panonija Savija u Justinijanovo doba" [Pannonia Savia in the Age of Justinian], in: Radovi XIII. međunarodnog kongresa za starokršćansku arheologiju: L'Époque de Justinien et les problèmes de VI et VII ${ }^{e}$ siècles, vol. 2, eds. Nenad Cambi and Emilio Marin (Split: Arheološki muzej, 1998), 1134. Contra Nada Miletić, "Reflets des grandes invasions en Bosnie-Herzégovine", in: Problemi seobe naroda u Karpatskoj kotlini. Saopštenja sa naučnog skupa 13.-16. decembra 1976. / Probleme der Völkerwanderungszeit im karpatenbecken. Mitteilungen des Symposiums 13.-16. Dezember 1976, eds. Danica Dimitrijević, Jovan Kovačević and Zdenko Vinski (Novi Sad: Matica srpska, 1978), 102.

${ }^{174}$ Cf. Gračanin and Škrgulja, "The Ostrogoths”, 180. 
government. What follows may be regarded as a preliminary examination, since a more refined and diversified insight would necessitate a comprehensive comparison of Pannonia and Dalmatia to Italy that would established more thoroughly the region's position within the Ostrogothic Kingdom, and an extensive exploration of how individual letters that are concerned with local provincial matters correlate with the entire collection in regard to the transmitted ideological charge, both of which warrant individual studies. For now it may be said that, when compared to other border regions of the Ostrogothic Kingdom, southern Pannonian and Dalmatian provinces are well represented in the Variae: fifteen letters deal exclusively with matters relating to Savia (3), Pannonia Sirmiensis (3) and Dalmatia (9), and the remaining seven letters (excluding two that are concerned with Histria) also contain related information. The matters pertaining to Gaul, which was a praefectura praetorio in its own right, are directly addressed in twenty four letters $(1.24 ; 3.16 ; 3.17 ; 3.18 ; 3.32 ; 3.34 ; 3.38 ; 3.40 ; 3.41 ; 3.42 ; 3.43 ; 3.44 ; 4.5 ; 4.7$; $4.12 ; 4.16 ; 4.17 ; 4.19 ; 4.21 ; 4.26 ; 5.10 ; 5.11 ; 8.6 ; 8.7)$, two of which deal with the Gepids' march through northern Italy, while in another seven letters the res Gallicanae figure as a more or less passing remark $(2.1 ; 2.2 ; 2.3 ; 5.33 .1 ; 8.10 .6,10$; $11.1 .13,16 ; 12.28 .2) .{ }^{175}$ The matters relating to Noricum and Raetia, on the other hand, are addressed to in only three letters taken together $(1.11 ; 3.50 ; 7.3)$. The region between the Danube and Adriatic Sea seems to have received a particular interest in the Variae, even if many more letters pertaining to Gaul, Noricum and Raetia were never included in the collection's final redaction (however, this also applies to Savia, Pannonia Sirmiensis and Dalmatia). One reason for this interest was undoubtedly the region's strategic importance, since southern Pannonia and Dalmatia offered an access to Italy by both land and sea (the latter was nicely illustrated in the war between the Eastern Empire and the Ostrogoths ${ }^{176}$ ). Savia and Pannonia Sirmiensis could be used as a potential reservoir of troops, considering that a large portion of their population seems to have been non-Roman by this time. The Variae themselves show Theoderic's using the Gepids to bolster Ostrogothic positions in Gaul, and Procopius of Caesarea mentions a Gothic army recruiting soldiers among the barbarians in Savia before launching an attack against Salona in 537. ${ }^{177}$ In addition, Dalmatia seems to have been a relatively prosperous province, judging by the obligation to pay siliquaticum and the apparent chief concern of the local middle class to acquire new properties, regardless of their self-professed plight through Arators' oratorial eloquence. ${ }^{178}$

\footnotetext{
${ }^{175}$ The consul ordinarius Felix, who hailed from Gaul and figures directly or indirectly as the main subject in letters 2.1,2.2, and 2.3, is also the subject of the letter 3.39.

${ }^{176}$ On this, see Ivo Goldstein, "How the Byzantines made use of the Adriatic Sea in the war against the Ostrogoths in 535-555", Zbornik radova Vizantološkog instituta 38 (1999 - 2000): 49-59. Wozniak, "The Continuity of Roman Traditions", 375, 378, also emphasizes the importance of Dalmatia.

${ }_{177}$ Procopius, Bellum Gothicum 1.16.8-9; with Gračanin and Škrgulja, “The Ostrogoths”, 185-186.

${ }^{178}$ On relative prosperity of Dalmatia in the 6th century in the context of local ecclesiastical circumstan-
} 
The other reason for this interest was ideological. Pannonia Sirmiensis by itself seems to have held a particular ideological significance as the quondam sedes Gothorum (3.23.1). It has already been inferred that Sirmium may have had special meaning as a former residence of the Roman emperors and possibily even where Ostrogothic kings resided during the first period of their stay in Pannonia. The expeditio Sirmiensis in 504 and subsequent fighting in the Middle Danube region against the Bulgars of the Eastern Roman army in 505 are presented as having conspicuous place in careers of both Tuluin and Cyprianus. ${ }^{179}$ The Variae actually treat both of these military events as a whole and depict them as fights against barbarian foes who pose a threat (the Bulgars are toto orbe terribiles, 8.10.4; and they even almost defeated the Goths, 8.21.3) or who seem to be perceived as standing in the way of bringing the Roman, i.e. Gothic authority where it belongs (the Danube is called gentilis, 8.21.3; and Amalasuntha makes the Danube Roman after the victory over the invasores, 11.1.10-11). ${ }^{180}$ The Ostrogothic Kingdom was undoubtedly viewed, as presented in the Variae, as a legitimate Roman state and one of two parts of a single Empire. ${ }^{181}$ Those parts did not always see eye to eye, and it was now for the Ostrogoths to look after the interests of the Western Empire, even if that meant clashing with the eastern counterpart. In this context, Illyricum played an important role in both political and ideological sense, since it was a contested area of long ago between the East and the West. In the letter addressed to the Roman Senate and dated to 533, Cassiodorus criticizes the western Roman empress Galla Placidia, "celebrated in the world's opinion and renowned through the lineage with certain emperors," for feebly ruling the Western Empire

ces, cf. ; with Ivanka Nikolajević, "Salona Cristiana aux VI et VII e siècles", in: Disputationes Salonitanae 1970, ed. Željko Rapanić (Split: Arheološki muzej, 1975), 94; Bruna Kuntić-Makvić, "Honorius Iunior, Salonitanae urbis episcopus. Essai sur la Dalmatie de son temps", in: Radovi XIII. međunarodnog kongresa za starokrš́ansku arheologiju: L'Époque de Justinien et les problèmes de VI et VII siècles, vol. 2, eds. Nenad Cambi and Emilio Marin (Split: Arheološki muzej, 1998), 997-1002. Wozniak, "The Continuity of Roman Traditions", 376, 377, 381, rather insists on favorable conditions in the province both before and under the Ostrogothic rule.

${ }^{179}$ Procopius, Bellum Gothicum, 1.11.5, seems to err when he connects Vitiges, who would become king of the Goths, to Theoderic's campaign against the Gepids. John Robert Martindale, The Prosopography of the Later Roman Empire, vol. IIIB: A.D. 527-641 (Cambridge: Cambridge University Press, 1992), 1382; Amory, People and Identity, 370, 460, make Vitiges participate in both the campaign of 504 and the campaign of 528. However, Vitiges appears to have only begun his career under Athalaric.

${ }^{180}$ The same notion of the Goths' liberating by their direct military involvement the Roman provinces from the barbarian domination is also visible in the case of southeastern Gaul, where the advent of Ostrogothic rule is presented as a restitution, after a long period of time, of the Roman practice (Romanae consuetudo) and the old freedom (antiqua libertas), i.e. the Roman law and order of things, as opposed to the barbarity (barbaries), the savagery of minds (mentium crudelitas) and the alien customs (mores alieni) (3.17.1; cf. also 3.43); with Sam J. Barnish, "Cuncta Italiae membra componere: Political Relations in Ostrogothic Italy", in: The Ostrogoths from the Migration Period to the Sixth Century: An Ethnographic Perspective, eds. Sam J. Barnish and Federico Marazzi (Woodbridge: Boydell Press, 2007), 331.

${ }^{181}$ 1.1.4: utraeque res publicae; 1.20.1: res publica Romana; 2.1.4: utraeque res publicae; 3.18.2: Romanum imperium; 10.21.2: Romana regna; 10.32.4: utraeque res publicae. With Amory, People and Identity, 53; Meyer-Flügel, Das Bild, 164-165. 
in the stead of her purple-clad son, which was shamefully diminished, since she acquired for herself a daughter-in-law by the loss of Illyricum, and the ruler's marriage union was accomplished by a lamentable division of provinces (11.1.9: Placidiam mundi opinione celebratam, aliquorum principum prosapia gloriosam purpurato filio studuisse percepimus, cuius dum remisse administrat imperium, indecenter cognoscitur imminutum. Nurum denique sibi amissione Illyrici comparavit factaque est coniunctio regnantis divisio dolenda provinciis). Referring to the events which happened a century or so ago from when he writes and seem to have cost the Western Empire not only the provinces of Eastern Illyricum, but also the provinces of Pannonia and Dalmatia, Cassiodorus apparently expresses both a long-lasting grudge of the Italo-Roman elite and reaffirms the position of the Ostrogoths who righted this wrong. This is made more clear in the continuance of the text, where the Ostrogothic queen Amalasuntha is, contrastingly, depicted as a prudent defender of Roman interests who, by a provident arrangement, keeps "our army" vigorous, neither worn down by incessant wars nor softened by long peace, and has managed to subject the Danube to the Roman, i.e. Gothic control, even against the intention of the eastern emperor ${ }^{182}$ (11.1.10: Sub hac autem domina ... noster exercitus terret externos: qui provida dispositione libratus nec assiduis bellis adteritur nec iterum longa pace mollitur ... contra Orientis principis votum Romanum fecit esse Danubium). The Gothic army deterred the invasores, by which surely the Gepids are meant, who are known from Procopius of Caesarea to have attacked Pannonia Sirmiensis in 528. ${ }^{183}$ A diplomatic choice of words in the Variae is more revealing than concealing, and shows that the Ravenna government was firmly convinced of the eastern Roman involvement: Cassiodorus somewhat condescendingly says that he omits that which the attackers have sustained, even though this is well-known, "lest the spirit of the allied prince should endure a loser's shame. For his opinion of our lands may be discerned from because, albeit offended, he granted peace which, despite the entreats, he refused to concede to others. Furthermore, even though so rarely requested, he has honored us with so many embassies, and that extraordinary power has bent the awe of the towering East so that it might elevate the lords of Italy" (11.1.11: Notum est quae pertulerint invasores: quae ideo praetermittenda diiudico, ne genius socialis principis verecundiam sustineat perditoris. Quid enim de nostris partibus senserit, hinc datur intellegi, quando pacem contulit laesus, quam aliis concedere noluit exoratus. Additur quod tantis nos legationibus tam raro requisitus ornavit et singularis illa potentia, ut Italicos dominos erigeret, reverentiam Eoi culminis inclinavit). ${ }^{184}$

\footnotetext{
${ }^{182}$ Note the implied criticism of the eastern emperor who suffers the Danube not being under Roman control.

${ }^{183}$ Procopius, Bellum Gothicum, 1.3.15; 1.11.5; with Gračanin and Škrgulja, “The Ostrogoths”, 185.

${ }^{184}$ It is worth noting that Emperor Justinian later made an official complaint in a letter to Amalasuntha about the Gothic incursion into the eastern Roman territory, stressing that the action was unprovoked (Procopius, Bellum Gothicum, 1.3.17; with Gračanin and Škrgulja, “The Ostrogoths”, 185).
} 
Hence, in a way, the possession of Pannonia and Dalmatia may have been viewed by the Ravenna government as an additional proof of the success of the Ostrogothic rule and an indication that they managed to reverse the mistake done by previous western Roman rulers.

Translating the high politics onto the regional level, this meant that the Ravenna government was all the more interested to establish, maintain and foster the civilitas - the culture of law-abidingness and the civility of life - in southern Pannonia and Dalmatia in every aspect, and the Variae communicate this quite clearly. ${ }^{185}$ To this end, Theoderic advises his officials to act in accordance with his custom (3.23.4: consuetudo nostra), that is his political-ideological program, which stands in sharp contrast with the perverted custom (perversa consuetudo) and detestable practices (consuetudines abominanter) of the local population. If necessary, the officials are to use the legal severity $(4.49 ; 5.14 .3)$ to compel the savage and ferocious minds of the people into an agreeable way of life (3.23.4), but are also asked to show benevolence even at the expense of their office (3.23.4), since this mirrors the royal acts of generosity $(5.14 .4 ; 9.9 .3)$. Yet, such a generosity must not be misused (5.14.4), the tax frauds have to be prevented (5.14.9), it cannot be condoned to deceit the royal authorities for personal profit (5.24.2) nor to allow unlawful and shameful acts out of greed (4.9). What the ruler, whose forethought (providentia: $3.24 .1 ; 4.13 ; 5.14 .9)$ watches over everything, desires is for people to have justice (iustitia, iustus and ius are recurring terms: 3.23 .3 ; 3.24.3; 4.9; 4.13.1; 5.14.1; 5.14.2; 5.14.3; 5.14.8; 5.15.1; 5.15.2; 5.24.1; 7.16.2; 8.4.1; 8.4.3; 9.8.1; 9.8.2; 9.9.1; 9.9.2). In order to help create a sustainable civilized and harmonious society, the best what they, his provincials $(5.10 .2 ; 5.14 .1 ; 5.14 .2)$, but also his subjects (3.24.1; $3.25 .1 ; 5.15 .1 ; 5.24 .2 ; 8.4 .1 ; 9.9 .5)$, can do is to imitate the Goths (3.24.4), live orderly and by good morals (4.49), and find relief in justice (3.24.3), since only by their acceptance of remedies that are offered by law could their grievances be done away (5.15.3). Ultimately, they all, the king, officials, soldiers and provincials, have to work together (5.15.1: cunctis laborantibus) to a common benefit (utilitas/tes publica/ae: 3.25 .2 ; 3.26; 5.14.9; 8.12.3; utilitas: 3.25 .1 ), which is the same as the king's benefit (utilitas/tes nostra/ae: 9.8.1; 9.9.1; 9.9.5) and the good of his kingdom (3.24.2: regni nostri utilitas). This is a vocabulary that was primarily meant to mo-

\footnotetext{
${ }^{185}$ Theoderic's civilitas ideology and its implications are a much discussed subject. Cf. Amory, People and Identity, 50-85, 116-118; Bjornlie, Politics and Tradition, 251-253; Giardina, Cassiodoro politico, 35-39 (= Idem, "Cassiodoro politico e il progetto delle Variae", 64-68); Kakridi, Cassiodors Variae, 339-347; Paola Martino, "Gothorum laus est civilitas custodita (Cassiodorus Variae 9.14.18)", Sileno 8 (1982): 3145; O’Donnell, Cassiodorus, 96-100; Marc Reydellet, "Théoderic et la civilitas", in: Teoderico e i Goti tra Oriente e Occidente. Congresso internazionale, Ravenna 28 settembre - 2 ottobre 1992, ed. Antonio Carile (Ravenna: Longo, 1995), 285-296; Biagio Saitta, La civilitas di Teodorico. Rigore amministrativo, "tolleranza" religiosa e recupero dell'antico nell'Italia ostrogota (Roma: "L'Erma" di Bretschneider, 1993); Nino Scivoletto, "Cassiodoro e la 'retorica della città", Giornalo Italiano di Filologia 38 (1986): 3-24; Aarne Stüven, Rechtliche Ausprägungen der civilitas im Ostgotenreich. Mit vergleichender Berücksichtigung des westgotischen und des burgundischen Rechts (Frankfurt am Main et al.: Peter Lang, 1995).
} 
tivate rather than coerce, but the coercive power is there, too, especially if there is no progress shown towards accomplishing the royal grand design. ${ }^{186}$

\section{Concluding remarks}

The Variae have much to offer both as a repository of valuable historical information for a well-founded insight into the life of Pannonia and Dalmatia under the Ostrogothic rule in the first half of the sixth century and as a literary testimony on how the region might have appeared to external observers. The letters also contain elements of political ideology of Ostrogothic kings transferred into local context, which can be used to define the place that the provinces were accorded to in communicating this ideology. The letters suggest the provincial administration of Dalmatia and Pannonia during the Ostrogothic period to be complex and well differentiated. It comprised of both military and civil officials with distinctly delineated functions. Much of the late Roman provincial system was maintained, but administrative innovations were also introduced, the most conspicuous of which was the creation of comitiva provinciae that united highest military and civil authority in the province, clearly indicating the militarized character of the Ostrogothic system of government. Apart from comites provinciae, at least one local comes Gothorum is attested on what it seems to be the municipal level, a military comes civitatis, presumably of Siscia. Further changes introduced by the Ostrogothic authorities was joining Savia and Dalmatia into one administrative unit united under a single comes provinciae as well as the creation of a separate comitiva for the islands of Krk and Cres in Kvarner Bay, which seems to have been civil in its character, and not a naval military district as is usually thought. At the same time, Savia and Dalmatia seem to have retained their own independent jurisdictions and separate civil Roman governors with judicial and fiscal authority over the Roman population. A Roman governor may possibly also have existed in Pannonia Sirmiensis. It is worth noting that the proper administrative name of the province Savia in the Ostrogothic period seems to have been Suavia, which is believed to have been due to a significant local presence of Suevi. The economic circumstances of the sixth-century Dalmatia and Pannonia can also be reconstructed to a certain degree thanks to the Variae. The problems with exacting taxes in the provinces are accorded much attention, especially with regard to Savia and Dalmatia, but this may not be seen as much differing from the situation in late Roman time. However, taking into account that the Roman provincial system practically ceased to exist in southern Pannonia in 430s, it is a sign of how the process of readapting to the former condition was for the local population slow and difficult, and was met with resistance. It also testifies to the fact that the sophisticated Roman system of taxation was reintroduced and maintained in the

\footnotetext{
${ }^{186}$ On the imperative communication in the context of the Roman imperial discourse, see Clifford Ando, Imperial Ideology and Provincial Loyalty in the Roman Empire (Berkeley; Los Angeles: University of California Press, 2000), 75-79.
} 
provinces, which was a remarkable achievement. In addition, Dalmatia seems to have experienced a certain level of prosperity, since it was reportedly liable to pay the sales tax siliquaticum, which would certainly indicate developed commercial activities. Moreover, the Ostrogothic authorities are also depicted as keen to revive the provincial mining industry, which seems to have had some success, considering that archaeological investigations have provided evidence for at least one mining facility in modern northwestern Bosnia and Herzegovina to have been operational under the subsequent eastern Roman rule. The letters also furnish a sufficiently instructive insight into the basic structure of provincial society in Dalmatia and Pannonia, that was along the lines of late Roman society, and indicate that the municipal system with defensores and curiales was maintained. There were also new groups represented in categories that are labeled as capillati and barbari antiqui. The latter is an ethno-cultural designation, too, and is believed to refer to the Suevic inhabitants of Savia. This granted, it is possible that it was a cover term for various other non-Roman groups residing within the province, excluding the Goths. The presence of Gothic population in the province is clearly attested to by the Variae, surely chiefly in provincial capitals. Considering that the address to the barbarians and Romans settled in Pannonia Sirmiensis is the only such address in the Variae, it may be taken as an indication that the non-Roman inhabitants had a significant share in the overall provincial population. Dalmatia, on the other hand, seems not to have a large number of non-Roman population, including the Goths. Furthermore, the Ostrogothic authorities are shown to have influenced actively the ethnic picture by resettling and admitting barbarian groups into their territory. The region appears to have had a conspicuous place in the political ideology of Ostrogothic government as a contested area between the Eastern and Western Roman Empires. In addition, Pannonia Sirmiensis is singled out as "the former seat of the Goths," a remark that reflects a special attachment that may have been felt by Theoderic to the province which had already been controlled by the Goths in the past, moreover probably held directly by Theoderic himself. The image of the provinces that emerges from the Variae is twofold. On the one hand, the provinces are depicted as plagued with various problems. This applies especially to Savia which is represented as being under siege by different kinds of transgressions, in which the entire social and administrative structure of the province seems to have been involved. On the other hand, the impression that inevitably comes forth is that there were incessant attempts and care by the central government to secure the orderly and law-abiding conditions of life, the civilitas. Thus the letters can be understood as conveying an unmistakable message that, thanks to the Gothic royal authority and capable and reliable court and government Roman civil servants, in spite of sometimes very adverse circumstances, southern Pannonian and Dalmatian provinces were preserved for the romanitas. 


\section{Addendum}

\section{An unexpected addition to the Variae dossier on Dalmatia?}

A new comprehensive edition of Cassiodorus' Variae with a complete Italian translation and a rich and thorough commentary, which is a most welcomed result of a joint effort by several Italian scholars under the direction of Andrea Giardina, has offered in its volume 5 a quite different interpretation of the letter 12.17 that, at first glance, may enrich the Variae dossier on Dalmatia. ${ }^{187}$ The letter's recipient is a (si)liquatarius of Ravenna named John and King Athalaric is mentioned as its addresser, even though another manuscript tradition would have Cassiodorus instead. ${ }^{188}$ The letter recounts instructions apparently given to the tax official who is to see that the possessores have taken care of digging out huge ditches near Mount Caprarius and places surrounded by walls as to prevent access to a city (civitas) that is not specifically named. It has been usually taken that this refers to Ravenna. However, the newest two commentators of a pertinent passage have proposed a different identification, opting for Salona in Dalmatia, whose walls are known from Procopius to have been in a rather sorry state on the onset of the Gothic war. ${ }^{189}$ The key argument to this rather original interpretation is the mention of a mons Caprarius which is otherwise unknown for the area of Ravenna, where no mountains or hills exist. On the other had, a mons Caprarius is likely to have existed in Roman times in the vicinity of Salona, and the modern Kozjak („Goat's Hill“) above the town of Kaštela near Split may preserve the original oronym in a Slavicized form. Although leaving the matter open for the time being, I am nevertheless not inclined to side with that Salona was meant in the letter. As I see it, the main problem is the mention of an official residing in Ravenna and his presumed jurisdiction in a province that administratively did not belong to the praetorian prefecture of Italy. One has only remember that when the Ravenna government wanted to have the due arrears of the siliquaticum collected a special commissioner who had been directly instructed by the king was sent to Dalmatia. Moreover, it also has to be accounted for a possibility that Cassiodorus was the actual addresser of the letter and not King Athalaric. Bearing all this in mind and considering that many toponyms Caprarius or Capraria or their variants are known from Italy, I believe that the mons Caprarius and the civitas with derelict walls from the letter are to be looked for in (presumably northern) Italy. Be that as it may, what seems to be fairly certain after this novel proposal is that Ravenna is to be removed from the identification.

\footnotetext{
${ }^{187}$ I was made aware of this new intepretation by a colleague of mine Trpimir Vedriš who presented it at the ASAS Antiquitatis sollemnia - Antidoron Mate Suić conference held in Zagreb and Zadar on 3-7 November 2015. He has kindly put his paper at my disposal, for which I wish to offer him my sincerest thanks.

${ }^{188}$ See Cassiodori Variarum libri XII, in: Magni Aurelii Cassiodori Senatoris Opera I, ed. Åke J. Fridh, (Corpus Christianorum. Series Latina 96), Turnhout: Brepols, 1973, 484.

${ }^{189}$ Maria Cristina La Rocca and Yuri Marano „Comment to 12.17“, in: Flavio Magno Aurelio Cassiodoro Senatore, Varie, vol. V: Libri XI-XII, eds. Andrea Giardina, Ciovanni Alberto Cecconi, and Ignazio Tantillos, Roma: „L'Erma“ di Bretschneider, 2015, 273-274. For Procopius' testimony, see Bellum Gothicum 1.7.9, 1.7.31, 1.7.36.
} 


\section{Bibliography}

\section{Primary Sources}

Cassiodoris Senatoris chronica ad a. DXIX. Ed. Theodor Mommsen, (Monumenta Germaniae Historica. Auctores Antiquissimi 11, Chronica minora 2). Berlin: Weidmann, 1894, 109-161.

Cassiodori Senatoris Variae. Ed. Theodorus Mommsen, (Monumenta Germaniae Historica. Auctores Antiquissimi 12). Berlin: Weidmann, 1894, 1-385.

Cassiodori Variarum libri XII. In: Magni Aurelii Cassiodori Senatoris Opera I, ed. Fridh, Åke J. (Corpus Christianorum. Series Latina 96). Turnhout: Brepols, 1973, 1-499.

Ennodio, Magno Felice. Panegirico del clementissimo re Teoderico (opusc. 1), ed. Simona Rota. Roma: Herder, 2002.

Ennodius, Panegyricus dictus clementissimo regi Theoderico. In: Christian Rohr, Der Theoderic-Panegyricus des Ennodius. Hannover: Hahnsche Buchhandlung, 1995.

Iordanis Romana et Getica. Ed. Theodor Mommsen, (Monumenta Germaniae Historica. Auctores Antiquissimi 5.1). Berlin: Weidmann 1882.

Menander Protector, Historia. In: The History of Menander the Guardsman, introductory essay, text, translation and historiographical notes by Roger C. Blockley, Liverpool: Francis Cairns, 1985.

La Notitia dignitatum: nueva edición crítica y comentario histórico. Ed. Concepción Neira Faleiro. Madrid: Consejo Superior de Investigaciones Científicas, 2005.

Notitia dignitatum in partibus Occidentis. In: Notitia dignitatum. Accedunt Notitia urbis Constantinopolitanae et Latercula provinciarum, ed. Otto Seeck. Berlin: Weidmann, 1876, 103-225 (Frankfurt am Main: Minerva, 1962).

Procopius, Bellum Gothicum. In: Procopius Caesariensis, Opera omnia II (De bellis libri V-VIII: Bellum Gothicum), ed. Jacob Haury, rev. Gerhard Wirth. Leipzig: B. G. Teubner, 1963.

Ravennatis Anonymi Comographia. In: Itineraria Romana II, ed. Joseph Schnetz. Leipzig: B. G. Teubner, 1940, 1-110.

Salona IV. Inscriptions de Salone chrétienne, IVe-VII siècles, vol. II. Eds. Nancy Gauthier, Emilio Marin and Françoise Prévot. Rome: École Française de Rome; Arheološki muzej Split, 2010.

\section{Secondary Sources}

Amory, Patrick. People and Identity in Ostrogothic Italy 489-554. Cambridge: Cambridge University Press, 2003. 
Ando, Clifford. Imperial Ideology and Provincial Loyalty in the Roman Empire. Berkeley; Los Angeles: University of California Press, 2000.

Antoljak, Stjepan. “Zadar unter ostgotischer Herrschaft”. Diadora 6 (1971): 207220.

Arnold, Jonathan J. Theoderic and the Roman Imperial Restoration. Cambridge: Cambridge University Press, 2014.

Ausbüttel, Frank M. Die Verwaltung der Städte und Provinzen im spätantiken Italien. Frankfurt am Main et al.: Peter Lang, 1988.

Barnish, Samuel J. B. Cassiodorus: Variae, (Translated Texts for Historians 12). Liverpool: Liverpool University Press, 1992 (repr. 2006).

Barnish, Samuel J. B. “Cuncta Italiae membra componere: Political Relations in Ostrogothic Italy". In: The Ostrogoths from the Migration Period to the Sixth Century: An Ethnographic Perspective, eds. Sam J. Barnish and Federico Marazzi, 317-337. Woodbridge: Boydell Press, 2007.

Barnish, Samuel J. B. "Roman Responses to an Unstable World: Cassiodorus" Variae in Context." In: Viarium in Context, 7-22. Vicenza: Centre for Medieval Studies Leonard Boyle, 2008.

Barnwell, Paul S. Emperor, Prefects \& Kings. The Roman West, 395-565. London: Duckworth, 1992.

Basić, Ivan. "Dalmatiae, Dalmatiarum: a study in historical geography of the Adriatic (in the light of the new inscription from Córdoba)". In: Illyrica Antiqua II: in honorem Duje Rendić-Miočević. Papers from the international conference held in Šibenik 12-15 September 2013, Zagreb: FF press. (forthcoming).

Basler, Đuro. "Naselje uz metalurški pogon u dolini rijeke Japre" [A Settlement next to the Metallurgical Facility in the Japra River Valley]. In: Materijali XIII (Simpozijum Antički gradovi $i$ naselja u južnoj Panoniji i graničnim područjima, Varaždin 1975), ed. Branka Vikić-Belančić, 137-146. Beograd: Savez arheoloških društava Jugoslavije, 1977.

Basler, Đuro. Spätantike und frühchristliche Architektur in Bosnien und der Herzegowina. Revised by Renate Pillinger, Andreas Pulz and Hermann Vetters. Wien: Verlag der Osterreichischen Akademie der Wissenschaften, 1993.

Besselaar, Joseph Jacobus van den. Cassiodorus Senator en zijn Variae. De hoveling de diplomatieke oorkonden der Variae de rhetor. Nijmegen; Utrecht: Dekker \& van de Vegt n. v., 1945.

Bierbrauer, Volker. Die ostgotischen Grab- und Schatzfunde in Italien. Spoleto: Centro Italiano di Studi sull'Alto Medioevo, 1976.

Bjornlie, Michael Shane. Politics and Tradition between Rome, Ravenna and Constantinople. A Study of Cassiodorus and the Variae 527-554. Cambridge: Cambridge University Press, 2013. 
Bjornlie, Michael Shane."The Rhetoric of Varietas and Epistolary Encyclopedism in the Variae of Cassiodorus". In: Shifting Genres in Late Antiquity, eds. Geoffrey Greatrex, Hugh Elton and Lucas McMahon, 289-303. Farnham: Ashgate, 2015.

Bratož, Rajko. Med Italijo in Ilirikom. Slovenski prostor in njegovo sosedstvo v pozni antiki [Between Italy and Illyricum. Slovene Territory and Its Neighborhood in Late Antiquity]. Ljubljana: Znanstvena založba Filozofske fakultete; Zveza zgodovinskih društev Slovenije; Slovenska Akademija znanosti in umetnosti, 2014.

Brown, Horatio F. "Venice". In: The Cambridge Medieval History, vol. IV: The Eastern Roman Empire (717-1453), eds. Joseph Robson Tanner, Charles William Previté-Orton, and Zachary N. Brooke, 385-414. Cambridge: Cambridge University Press, 1923.

Burns, Thomas S. The Ostrogoths: Kingship and Society. Wiesbaden: Franz Steiner Verlag, 1980.

Burns, Thomas S. A History of the Ostrogoths. Bloomington: Indiana University Press, 1984.

Castritius, Helmut. "Korruption im ostgotischen Italien". In: Korruption im Altertum. Konstanzer Symposium Oktober 1979, ed. Wolfgang Schuller, 214-234. München-Wien: R. Oldenbourg Verlag, 1982.

Castritius, Helmut. 1995. "Barbari - antiqui barbari. Zur Besiedlungsgeschichte Südostnoricums und Südpannoniens in der Spätantike (Ende des 4. bis Mitte des 6. Jahrhunderts n. Chr.)". Frühmittelalterliche Studien 29 (1995): 72-85.

Cecconi, Giovanni A."Honorati, possessores, curiales: competenze istituzionali e gerarchie di rango della città tardoantica”. In: Le trasformazioni delle élites in età tardoantica. Atti del convegno internazionale, Perugia, 15-16 marzo 2004, ed. Rita Lizzi Testa, 41-60. Roma: L'Erma di Bretschneider, 2006.

Cecconi, Giovanni A. „Comment to 7.16“. In Flavio Magno Aurelio Cassiodoro Senatore, Varie, vol. III: Libri VI-VII, eds. Andrea Giardina, Giovanni Alberto Cecconi, and Ignazio Tantillo, 229-231. Roma: „L'Erma“ di Bretschneider, 2015.

Curchin, Leonard A. "The end of local magistrates in the Roman Empire". Gerión 31 (2014): 271-287.

De Salvo, Lietta. Economia privata e pubblici servizi nell'Impero romano. I corpora naviculariorum. Messina: Samperi editore, 1992.

Delmaire, Roland. Largesses sacrées et res privata. Laerarium impérial et son administration du $I V^{e}$ au $V I^{e}$ siècle. Rome: École française de Rome, 1989.

Deproost, Paul-Augustin. L'Apôtre Pierre dans une épopée du VI siècle: l'Historia apostolica d'Arator. Paris: Institut d'études augustiniennes, 1990. 
Diculescu, Constantin C. Die Gepiden. Forschungen zur Geschichte Daziens im frühen Mittelalter und zur Vorgeschichte des rumänischen Volkes, vol. 1. Leipzig: C. Kabitzsch, 1923.

Ensslin, Wilhelm. "Aus Theoderichs Kanzlei". Würzburger Jahrbücher für Altertumswissenschaften 2 (1947): 75-85.

Ensslin, Wilhelm. Theoderich der Grosse, 2nd ed. München: Verlag F. Bruckmann, 1959.

Everett, Nicholas. "Lay documents and archives in early medieval Spain and Italy, c. 400-700". In: Documentary Culture and Laity in the Early Middle Ages, eds. Warren Brown, Marios Costambeys, Matthew Innes and Adam Kosto, 63-94. Cambridge: Cambridge University Press, 2013.

Fitz, Jenö. L'administration des provinces pannoniennes sous le Bas-Empire romain. Bruxelles: Latomus, 1983.

Fridh, Åke J. Études critiques et syntaxiques sur les Variae de Cassiodore. Göteborg: Wettergren \& Kerber, 1950.

Fridh, Åke J. Terminologie et formules dans les Variae de Cassiodore. Études sur le développement du style administratif aux derniers siècles de l'antiquité. Stockholm: Almquist \& Wiksell, 1956.

Fridh, Åke J. Contributions à la critique et à l'interprétation des Variae Cassiodore. Göteborg: Elanders Boktryckeri Aktiebolag, 1968.

Gatto, Ludovico."Il Mare Adriatico nelle 'Variae' di Cassiodoro". In: L'Adriatico dalla tarda antichità all'età carolingia. Atti del convegno di studio, Brescia 11-13 ottobre 2001, eds. Gian Pietro Brogiolo and Paolo Delogu, 271-286. Firenze: All'Insegno del Giglio, 2005.

Giardina, Andrea. "Cassiodoro politico e il progetto delle Variae". In: Teoderico il Grande e i Goti d'Italia. Atti del XIII Congresso internazionale di studi sull'Alto Medioevo, Milano 2-6 novembre 1992, vol. I, 45-76. Spoleto: Centro italiano di studi sull'Alto Medioevo 1993.

Giardina, Andrea. Cassiodoro politico. Roma: L'Erma di Bretschneider, 2006.

Gillett, Andrew. "The Purpose of Cassiodorus' Variae". In After Rome's Fall. Narrators and Sources of Early Medieval History. Essays presented to Walter Goffart, ed. Alexander Callander Murray, 37-50. Toronto-Buffalo-London: University of Toronto Press, 1998.

Gillett, Andrew. Envoys and Political Communication in the Late Antique West, 411-533. Cambridge: Cambridge University Press, 2003.

Goffart, Walter. "From Roman Taxation to Medieval Seigneurie: Three Notes". In: Idem, Rome's Fall and After, 168-177. London; Ronceverte: The Hambledon Press, 1989. 
Goffart, Walter. "Merovingian Polyptychs: Reflections on Two Recent Publications". In: Idem, Rome's Fall and After, 233-253. London; Ronceverte: The Hambledon Press, 1989.

Goldstein, Ivo. "How the Byzantines made use of the Adriatic Sea in the war against the Ostrogoths in 535-555". Zbornik radova Vizantološkog instituta 38 (1999-2000): 49-59.

Gračanin, Hrvoje. "Goti i južna Panonija" [The Goths and Southern Pannonia]. Scrinia Slavonica 6 (2006): 83-126.

Gračanin, Hrvoje. “The Huns and South Pannonia”. Byzantinoslavica 64 (2006): 29-76.

Gračanin, Hrvoje. Južna Panonija u kasnoj antici i ranom srednjovjekovlju (od konca 4. do konca 11. stoljeća) [Southern Pannonia in Late Antiquity and the Early Middle Ages (from the late 4 th to the late 11th centuries)]. Zagreb: Plejada, 2011.

Gračanin, Hrvoje. "Crkveni ustroj u kasnoantičkoj južnoj Panoniji” [Ecclesiastical Organization in Southern Pannonia in Late Antiquity]. Croatica Christiana periodica 38 (2014), no. 73: 1-12 (= in Znakovi i riječi 4 - Signa et litterae IV. Zbornik projekta "Mythos - cultus - imagines deorum". De ritv ad religionem Od obreda do vjere, eds. Bruna Kuntić-Makvić and Inga Vilogorac Brčić, 155169. Zagreb: FF press, 2013.).

Gračanin, Hrvoje. "The history of the eastern Adriatic region from the $\mathrm{v}^{\text {th }}$ to the viit ${ }^{\text {th }}$ centuries AD: historical processes and historiographic problems". In: AdriaAtlas et l'histoire de l'espace adriatique du VI ${ }^{e}$ s. a.C. au VIII ${ }^{e}$ s. p.C. Actes $d u$ colloque international de Rome (4-6 novembre 2013), eds. Yolande Marion and Francis Tassaux, 67-97. Bordeaux: Ausonius Éditions, 2015.

Gračanin, Hrvoje; Škrgulja Jana. "The Ostrogoths in Late Antique Southern Pannonia”. Acta Archaeologica Carpathica 49 (2014) [2015]: 165-205.

Hardt, Matthias. Gold und Herrschaft. Die Schätze europäischer Könige und Fürsten im ersten Jahrtausend. Berlin: Akademie Verlag, 2004.

Hartmann, Ludo Moritz. Geschichte Italiens im Mittelalter, vol. II/2: Die Loslösung Italiens vom Oriente. Gotha: Friedrich Andreas Perthes (repr. Hildesheim: Georg Olms Verlag, 1969), 1903.

Hasenstab, Benedikt. Studien zur Variensammlung des Cassiodorius Senator. Ein Beitrag zur Geschichte der Ostgotenherrschaft in Italien. München: Akademische Buchdruckerei von F. Straub, 1883.

Heather, Peter. "Merely and Ideology? - Gothic Indentity in Ostrogothic Italy". In: The Ostrogoths from the Migration Period to the Sixth Century: An Ethnographic Perspective, eds. Sam J. Barnish and Federico Marazzi, 31-60. Woodbridge: Boydell Press, 2007. 
Henning, Dirk. Periclitans res publica. Kaisertum und Eliten in der Krise des Weströmischen Reiches 454/5-493 n.Chr. Stuttgart: Franz Steiner Verlag, 1999.

Hillier, Richard. Arator on the Acts of the Apostles. A Baptismal Commentary. Oxford: Clarendon Press, 1993.

Hodgkin, Thomas. The letters of Cassiodorus, being a condensed translation of the Variae epistolae of Magnus Aurelius Cassiodorus Senator. London: Henry Frowde, 1886.

Hoffmann, Richard C. "Carp, Cods, Connections: New Fisheries in the Medieval European Economy and Environment". In: Animals in Human Histories. The Mirror of Nature and Culture, ed. Mary J. Henninger-Voss, 3-55. Rochester: University of Rochester Press, 2002.

Jones, Arnold Hugh Martin. The Later Roman Empire, 284-602: A Social, Economic, and Administrative Survey, vols. 1-3. Oxford: Basil Blackwell, 1964.

Jouanaud, Jean-Louis. "Pour qui Cassiodore a-t-il publié les Variae?” In: Teoderico il Grande e i Goti d'Italia. Atti del XIII Congresso internazionale di studi sull'Alto Medioevo, Milano 2-6 novembre 1992, vol. II, 721-742. Spoleto: Centro italiano di studi sull'Alto Medioevo, 1993.

Kakridi, Christina. Cassiodors Variae. Literatur und Politik im ostgotischen Italien. München-Leipzig: K. G. Saur, 2005.

Karayannopulos, Iohannes. Das Finanzwesen des frübyzantinischen Staates. München: R. Oldenbourg, 1958.

Kopáčková, Jana. "Production of Wine and Olive Oil in Roman Histria and Dalmatia in Late Antiquity”. Studia Hercynia 18 (2014), nos. 1-2: 75-88.

Krautschick, Stefan. Cassiodor und die Politik seiner Zeit. Bonn: Dr. Rudolf Habelt, 1983.

Kuntić-Makvić, Bruna. "Honorius Iunior, Salonitanae urbis episcopus. Essai sur la Dalmatie de son temps". In: Radovi XIII. medunarodnog kongresa za starokršćansku arheologiju: L'Époque de Justinien et les problèmes de VI et VII siècles, vol. 2, eds. Nenad Cambi and Emilio Marin, 997-1002. Split: Arheološki muzej, 1998.

Lafferty, Sean D. W. Law and Society in the Age of Theoderic the Great. A Study of the Edictum Theoderici. Cambridge; New York: Cambridge University Press, 2013.

Leonardi, Claudio. Dizionario Biografico degli Italiani, vol. III (Ammirato-Arcoleo), ed. Alberto M. Ghisalberti. Roma: Istituto della Enciclopedia Italiana, s.v. Aratore, 1961, at http://www.treccani.it/enciclopedia/aratore_\%28Dizionario_ Biografico\%29/ (accessed 6 September 2015). 
Liebeschuetz, John Hugo Wolfgang Gideon. "Barbarians and Taxes". In: Idem, East and West in Late Antiquity: Invasion, Settlement, Ethnogenesis and Conflicts of Religion, 167-190. Leiden: Brill, 2015.

Lotter, Friedrich. Völkerverschiebungen im Ostalpen-Mitteldonau-Raum zwischen Antike und Mittelalter (375-600). Under collaboration by Rajko Bratož and Helmut Castritius. Berlin; New York: Walter de Gruyter, 2003.

Macpherson, Robin. Rome in involution. Cassiodorus' Variae in their literary and historical setting. Poznań: Wydawnictvo naukowe uniwersytetu Im. Adama Mickiewicza w Poznaniu, 1989.

Maier, Gideon. Amtsträger und Herrscher in der Romania Gothica. Vergleichende Untersuchungen zu den Institutionen der ostgermanischen Völkerwanderungsreiche. Stuttgart: Franz Steiner Verlag, 2005.

Marcone, Arnaldo. "Comment to 12.24". In: Flavio Magno Aurelio Cassiodoro Senatore, Varie, vol V: Libri Xi-XII, eds. Andrea Giardina, Ciovanni Alberto Cecconi and Ignazio Tantillos, 291-293. Roma: "L'Erma" di Bretschneider, 2015.

Margetić, Lujo. "Noviji pogledi na stariju povijest Vinodola, Krka i Senja" [Newer Views on Older History of Vinodol, Krk and Senj]. Zbornik Pravnog fakulteta u Rijeci 9 (1988): 1-19.

Martindale, John Robert. The Prosopography of the Later Roman Empire, vol. II: A.D. 305-527. Cambridge: Cambridge University Press, 1980.

Martindale, John Robert. The Prosopography of the Later Roman Empire, vol. IIIA-B: A.D. 527-641. Cambridge: Cambridge University Press, 1992.

Martino, Paola. "Gothorum laus est civilitas custodita (Cassiodorus Variae 9.14.18)". Sileno 8 (1982): 31-45.

Matijašić, Robert. "Kasiodorova pisma kao izvor za poznavanje kasnoantičke povijesti Istre" [Cassiodorus' Letters as a Source for the Knowledge of Late Antique History of Istria]. Zgodovinski časopis 42 (1988), no. 3: 363-371.

Matijašić, Robert. "Le isole di Cherso e Lussino in età romana". Atti del Centro di Ricerce Storiche di Rovigno 20 (1989 - 1990): 255-273.

Matijašić, Robert. "Oil and wine production in Istria and Dalmatia in classical antiquity and the early middle ages". In: La production $d u$ vin et de l'huile en Mediterranée - Oil and Wine Production in the Mediteranean Area. Actes du symposium international organisé par le Centre Camille Julian et le Centre archéologique du Var, Aix en Provence et Toulon, 20-22 novembre 1991, eds. Marie-Claire Amouretti and Jean-Pierre Brun, 247-261. Paris: École Française d'Athènes; De Boccard, 1993. 
Matijašić, Robert. "Sredozemno prehrambeno trojstvo u antici na Jadranu [Mediterranean nutritional trinity in the ancient period in the Adriatic]". In: Cerealia, oleum, vinum... Kultura prehrane i blagovanja na jadranskom prostoru, 3. Istarski povijesni biennale. Zbornik radova s medunarodnog znanstvenog skupa, vol. 3, eds. Marija Mogorović Crljenko and Elena Uljančić-Vekić, 37-54. Poreč: Zavičajni muzej Poreštine; Državni arhiv u Pazinu; Sveučilište Jurja Dobrile Odjel za humanističke znanosti, 2009.

Matijašić, Robert. Povijest hrvatskih zemalja u kasnoj antici od Dioklecijana do Justinijana [A History of Croatian Lands in Late Antiquity from Diocletian to Justinian]. Zagreb: Leykam international, 2012.

Medini, Julijan. "Provincia Liburnia”. Diadora 9 (1980): 363-435.

Meyer-Flïgel, Beat. Das Bild der ostgotisch-römischen Gesselschaft bei Cassiodor. Leben und Ethik von Römern und Germanen in Italien nach dem Ende des Weströmischen Reiches. Bern et al.: Peter Lang, 1992.

Miletić, Nada."Reflets des grandes invasions en Bosnie-Herzégovine". In: Problemi seobe naroda u Karpatskoj kotlini. Saopštenja sa naučnog skupa 13.-16. decembra 1976. / Probleme der Völkerwanderungszeit im karpatenbecken. Mitteilungen des Symposiums 13.-16. Dezember 1976, eds. Danica Dimitrijević, Jovan Kovačević and Zdenko Vinski, 97-108. Novi Sad: Matica srpska, 1978.

Mommsen, Theodor. "Ostgotische Studien". In: Idem, Gesammelte Schriften, vol. 6, 362-484. Berlin: Weidmanische Buchhandlung, 1910.

Moorhead, John. Theoderic in Italy. Oxford: Clarendon Press, 1997.

Morosi, Roberto. "Lattività del 'praefectus praetorio' nel regno ostrogoto attraverso le 'Variae' di Cassiodoro". Humanitas 27-28 (1975 - 1976): 71-94.

Morosi, Roberto. “I 'saiones', speciali agenti di polizia presso i Goti”. Athenaeum 59 (1981): 150-165.

Neri, Valerio. "Il lessico sociologico della tarda antichità: l'esempio delle 'Variae' di Cassiodoro". Studi storici 51 (2010), no. 1: 5-52.

Nikolajević, Ivanka. "Veliki posed u Dalmaciji u V i VI veku u svetlosti arheoloških nalaza" [The Large Estate in Dalmatia in the 5th and 6th Centuries in the Light of Archaeological Finds]. Zbornik radova Vizantološkog instituta 13 (1971): 277-291.

Nikolajević, Ivanka. "Salona Cristiana aux VI e et VIIe siècles". In: Disputationes Salonitanae 1970, ed. Željko Rapanić, 91-95. Split: Arheološki muzej, 1975.

Novak, Andrej. L'Istria nella prima età bizantina. Rovigno; Fiume; Trieste: Centro di ricerche storiche; Unione italiana; Università popolare, 2007.

Noyé, Ghislaine. "Social Relations in Southern Italy". In: The Ostrogoths from the Migration Period to the Sixth Century: An Ethnographic Perspective, eds. Sam J. Barnish and Federico Marazzi, 183-202. Woodbridge: Boydell Press, 2007. 
O'Donnell, James J. Cassiodorus. Berkeley; Los Angeles; London: University of California Press, 1979.

The Oxford Dictionary of Christian Church. Eds. Frank Leslie Cross and Elizabeth A. Livingston, revised 3rd ed. Oxford: Oxford University Press, s.v. Arator, 2005.

Paulys Realenzyclopädie der classischen Altertumswissenschaft, Supplementband 8, Stuttgart, 1956.

Pavan, Massimiliano. "La missione in Dalmazia del poeta Aratore". Atti e memorie della Società dalmata di storia patria 13 (1988 - 1989): 621-632.

Pellegrino, Angelo. "I navicularii maris Hadriatici ad Ostia". Miscellanea greca e romana 11 (1987): 229-236.

Pferschy, Bettina. "Cassiodors Variae. Individuelle Ausgestaltung eines spätrömischen Urkundenformulars”. Archiv für Diplomatik 32 (1986): 1-127.

Posavec, Vladimir. "Prilog poznavanju ostrogotskog razdoblja u Dalmaciji” [A Contribution to the Knowledge of Ostrogothic Period in Dalmatia]. Historijski zbornik 49 (1996): 1-15.

Posavec, Vladimir. Dalmacija u vrijeme Marcelina i Julija Nepota [Dalmatia in the Time of Marcellinus and Julius Nepos]. Split: Književni krug, 2007.

Prostko-Prostynski, Jan. "Zur Chronologie der Bücher VI und VII der 'Variae' von Cassiodor". Historia 53 (2004), no. 4: 503-508.

Radici Colace, Paola. "Lessico monetario in Cassiodoro: simbologia della moneta e filosofia del linguaggio". In: Cassiodoro: dalla corte di Ravenna al Vivarium di Squillace. Atti del Convegno Internazionale di Studi, Squillace, 25-27 ottobre 1990, ed. Sandro Leanza, 159-176. Soveria Mannelli: Rubbettino, 1993.

Reydellet, Marc. "Théoderic et la civilitas". In: Teoderico e i Goti tra Oriente e Occidente. Congresso internazionale, Ravenna 28 settembre - 2 ottobre 1992, ed. Antonio Carile, 285-296. Ravenna: Longo, 1995.

Rohde, Dorothea. Zwischen Individuum und Stadtgemeinde. Die Integration von collegia in Hafenstädten. Mainz: Verlag Antike e.K, 2012.

Ruggini, Lellia. Economia e società nell'"Italia Annonaria". Rapporti fra agricoltura e commercio dal IV al VI secolo d. C. Milano: Dott. A. Giuffrè Editore (2nd ed. Bari: Edipuglia, 1995), 1961.

Saitta, Biagio. La civilitas di Teodorico. Rigore amministrativo, "tolleranza" religiosa e recupero dell'antico nell'Italia ostrogota. Roma: "L'Erma" di Bretschneider, 1993.

Saitta, Biagio."The Ostrogoths in Italy". Polis. Revista de ideas y formas politicas de la Antigüedad Clásica 11 (1999): 197-216. 
Saria, Balduin. 1956. Paulys Realenzyclopädie der classischen Altertumswissenschaft, Supplementband 8, Stuttgart 1956, cols. 21-59, s.v. Dalmatia.

Schäfer, Christoph. Der weströmische Senat als Träger antiker Kontinuität unter den Ostgotenkönigen (490 - 540 n. Chr.). St. Katharinen: Scripta Mercaturae Verlag, 1991.

Schmidt, Ludwig. "Die comites Gothorum. Ein Kapitel zur ostgotischen Verfassungsgeschichte". Mitteilungen des Österreichischen Instituts für Geschichtsforschung 40 (1925): 127-133.

Schmidt, Ludwig. "Zur Geschichte Rätiens unter der Herrschaft der Ostgoten". Zeitschrift für schweizerische Geschichte 14 (1934): 451-459.

Schmidt-Hofner, Sebastian. Reagieren und Gestalten. Der Regierungsstil des spätrömischen Kaisers am Beispiel der Gesetzgebung Valentinians I. München: Verlag C.H. Beck, 2008.

Schmidt-Hofner, Sebastian. "Der defensor civitatis und die Entstehung des Notabelnregiments in den spätrömischen Städten”. In Chlodwigs Welt. Organisation von Herrschaft um 500, eds. Mischa Meier and Steffen Patzold, 487-522. Stuttgart: Franz Steiner Verlag, 2014.

Schwarcz, Andreas. "Der Nordadria- und Westbalkanraum im 6. Jahrhundert zwischen Goten und Byzantiner", In: Slovenija in sosednje dežele med antiko in karolinško dobo. Začetki slovenske etnogeneze / Slowenien und die Nachbarländer zwischen Antike und karolingischer Epoche. Anfänge der slowenischen Ethnogenese, vol. 1, ed. Rajko Bratož, 59-71. Ljubljana: Narodni muzej Slovenije, 2000.

Schwind, Johannes. Arator-Studien. Göttingen: Vandenhoeck \& Ruprecht, 1990.

Schwind, Johannes. Der Neue Pauly. Enzyklopädie der Antike, vol. I (A-Ari), eds. Hubert Cancik and Helmuth Schneider. Stuttgart \& Weimar: Verlag J.B. Metzlar, s.v. Arator, 1996.

Schwind, Johannes. Metzler Lexikon antiker Autoren, ed. Oliver Schütze. Stuttgart \& Weimar: Verlag J.B. Metzler, s.v. Arator, 1997.

Schwind, Johannes. Lexikon der antiken christlichen Literatur, eds. Siegmar Döpp and Wilhelm Geerlings, 3rd ed., Freiburg; Basel; Wien: Herder, s.v. Arator, 2002.

Scivoletto, Nino. "Cassiodoro e la 'retorica della città". Giornalo Italiano di Filologia 38 (1986): 3-24.

Sirago, Vito A. "I Goti nelle Variae di Cassiodoro". In: Atti della Settimana di studi su Flavio Magno Aurelio Cassiodoro (Cosenza-Squillace, 19-24 settembre 1983), ed. Sandro Leanza, 179-205. Soveria Mannelli: Rubbettino, 1986.

Skahill, Bernhard Henry. The Syntax of the Variae of Cassiodorus. Washington, D.C.: The Catholic University of America Press, 1934. 
Sokol, Vladimir. "Panonija Savija u Justinijanovo doba" [Pannonia Savia in the Age of Justinian]. In: Radovi XIII. međunarodnog kongresa za starokršćansku arheologiju: L'Époque de Justinien et les problèmes de VI et VII siècles, vol. 2, eds. Nenad Cambi and Emilio Marin, 1131-1143. Split: Arheološki muzej. 1998.

Staab, Franz. "Ostrogothic Geographers at the Court of Theodoric the Great: A Study of Some Sources of the Anonymous Cosmographer of Ravenna". Viator 7 (1976): 27-58.

Staab, Franz. Reallexikon der Germanischen Altertumskunde, vol. 11, 2nd ed., Berlin; New York: de Gruyter, s.v. Geograph von Ravenna 1998.

Stein, Ernst. "Untersuchungen zur spätrömischen Verwaltungsgeschichte". In: Idem, Opera minora selecta, 145-193. Amsterdam: Adolf M. Hakkert. 1968.

Stein, Ernst. Histoire du Bas-Empire, vol. 2. Amsterdam: Adolf M. Hakkert.

Stüven, Aarne. 1995. Rechtliche Ausprägungen der civilitas im Ostgotenreich. Mit vergleichender Berücksichtigung des westgotischen und des burgundischen Rechts. Frankfurt am Main et al.: Peter Lang, 1968.

Suelzer, Mary Josephine. The Clausulae in Cassiodorus. A Dissertation. Washington, D.C.: The Catholic University of America Press, 1944.

Suić, Mate. "Granice Liburnije kroz stoljeća" [Borders of Liburnia Through Centuries]. Radovi Instituta JAZU u Zadru 2 (1955): 273-296.

Suić, Mate. Prošlost Zadra, vol. I: Zadar u starom vijeku [Zadar's Past: Zadar in Antiquity]. Zadar: Filozofski fakultet u Zadru, 1981.

Šašel, Jaroslav. "Antiqui Barbari. Zur Besiedlungsgeschichte Ostnoricums und Pannoniens im 5. und 6. Jahrhundert nach den Schriftquellen", In: Von der Spätantike zum frühen Mittelalter. Aktuelle Probleme in historischer und archäologischer Sicht, eds. Joachim Werner and Eugen Ewig, 125-139. Sigmaringen: Jan Thorbecke, 1979.

Šišić, Ferdo. Povijest Hrvata u vrijeme narodnih vladara [A History of Croats in the Time of National Rulers]. Zagreb: Naklada školskih knjiga (repr. Zagreb: Nakladni zavod Matice hrvatske, 1990), 1925.

Škegro, Ante. “Bergbau der Römischen Provinz Dalmatien”. Povijesni prilozi 17 (1998): 17-105.

Škrgulja, Jana. "Larcheologia dell'Adriatico orientale tra il V ed il VII secolo: le evidenze archeologiche e i problemi della ricerca". In: AdriaAtlas et l'histoire de l'espace adriatique du VI' s. a.C. au VIII' s. p.C. Actes du colloque international de Rome (4-6 novembre 2013), eds. Yolande Marion and Francis Tassaux, 99-111. Bordeaux: Ausonius Éditions, 2015.

Škrgulja, Jana; Gračanin, Hrvoje. “Barbaricum contra imperium: Prostor današnje jugozapadne Vojvodine između kasne antike i ranog srednjeg vijeka u svjetlu 
povijesnih i arheoloških svjedočanstava (5.-6. stoljeće)" [Barbaricum contra imperium: The Territory of Modern Southwestern Vojvodina between Late Antiquity and the Early Middle Ages in Light of Historical and Archaeological Evidence (5th-6th c.)]. In: Vojvođanski prostor u kontekstu evropske istorije. Zbornik radova / The Region of Vojvodina in the Context of European History. Book of Proceedings 2, eds. Vladan Gavrilović and Svetozar Boškov, 7-39. Novi Sad; Bačka Palanka: Filozofski fakultet u Novom Sadu, 2014.

Tabata, Kayoko. "I comites Gothorum e l'amministrazione municipale in epoca Ostrogota". In: 'Humana Sapit'. Études d'Antiquité tardive offertes à Lellia Cracco Ruggini, eds. Jean-Michel Carrié and Rita Lizzi Testi, 67-78. Turnhout: Brepols.

Thraede, Klaus. 2001. Reallexikon für Antike und Christentum, suppl. vol. I (Aaron-Biographie II), eds. Theodor Klauser et al., Stuttgart: Anton Hiersemann, 2002.

Turković, Tin. “The Late Antique 'Palace' in Polače Bay (Mljet) - Tetrarchic 'Palace'?". Hortus Artium Medievalium 17 (2011): 211-233.

Turković, Tin; Basić, Ivan. "Nuove conoscenze sulla Liburnia Tarsaticensis nel contesto dello studio delle fonti geografiche". Atti del Centro di Ricerce Storiche di Rovigno 41 (2011): 49-102.

Turković, Tin; Basić, Ivan. "Kasnoantička i ranosrednjovjekovna Tarsatička Liburnija (Liburnia Tarsaticensis) u svjetlu geografskih izvora" [Late Antique and the Early Medieval Liburnia Tarsaticensis in Light of Geographical Sources]. Starohrvatska prosvjeta 3rd ser. 40 (2013): 33-80.

Uglešić, Ante. "Rimska provincija Dalmacija pod vlašću Istočnih Gota" [The Roman Province of Dalmatia under the Rule of the Ostrogoths]. Radovi Filozofskog fakulteta u Zadru 30 (1990 - 1991), no. 17: 65-78.

Uglešić, Ante. "Nalaz fibule seobe naroda iz Brguda kod Benkovca" [A Migration-Period Find from Brgud near Benkovac], Archaeologica Adriatica 3 (2009): 183-190.

Uroda, Nikolina. "Beginnings of monasticism on central Dalmatian islands problems and perspectives". Hortus Artium Medievalium 19 (2013): 113-120.

Vidén, Gunhild. The Roman Chancery Tradition. Studies in the Language of Codex Theodosianus and Cassiodorus' Variae. Gothenburg: Acta Universitatis Gothoburgensis, 1984.

Vinski, Zdenko. "Rani srednji vijek u Jugoslaviji od 400. do 800. godine" [The Early Middle Ages in Jugoslavia from 400 to 800 AD]. Vjesnik Arheološkog muzeja u Zagrebu 3rd ser. 5 (1971): 47-71.

Viscido, Lorenzo. "Sull'uso del termine barbarus nelle 'Variae' di Cassiodoro". Orpheus 7 (1986), no. 2: 338-344. 
Viscido, Lorenzo. Lessico zoologico nelle "Variae" di Cassiodoro, 2nd ed. Catanzaro: Grafiche Lucia, 2010.

Wilkes, John J. Dalmatia. London: Routledge \& Kegan Paul, 1969.

Wolfram, Herwig. Die Goten. Von den Anfängen bis zur Mitte des sechsten Jahrhunderts. Entwurf einer historischen Ethnographie, 3rd ed. München: Verlag C. H. Beck, 1990.

Wozniak, Frank E. "East Rome, Ravenna and Western Illyricum". Historia 30 (1981), no. 3: 351-382.

Wozniak, Frank E. "The Continuity of Roman Traditions and the Ostrogothic Administration of Dalmatia in the Sixth Century". In: Papers for the V. Congress of Southeast European Studies (Belgrade, September 1984), eds. Kot K. Shangriladze and Erica W. Townsend, 374-382. Columbus: Slavica Publishers, 1984.

Zaninović, Marin. "Avsonius vir spectabilis. Novi namjesnik kasnoantičke Dalmacije" [Avsonius vir spectabilis. A New Governor of Late Antique Dalmatia]. Prilozi povijesti umjetnosti u Dalmaciji 26 (1987), no. 1: 11-22.

Zaninović, Marin. "Ausonius vir spectabilis. Nuovo luogotenente della Dalmazia tardoantica". In: Actes du IXe Congrès international dépigraphie grecque et latine. Acta Centri Historiae Terra Antiqua Balcanica, vol. II, eds. Aleksandr Fol, Vladimir Živkov and Nikolai Nedjalkov, 288. Sofia: Terra Antiqua Balcanica, 1987.

Zaninović, Marin. "Sol u antici naše obale" [Salt in Antiquity of Our Coast]. In Zbornik radova posvećenih akademiku Alojzu Bencu, ed. Borivoj Čović, 255264. Sarajevo: Akademija nauka i umjetnosti Bosne i Hercegovine, 1991.

Ziemann, Daniel. Von Wandervolk zur Großmacht. Die Entstehung Bulgariens im frühen Mittelalter (7.-9. Jh.). Köln; Weimar; Wien: Böhlau Verlag, 2007.

Zimmermann, Odo John. The Late Latin Vocabulary of the Variae of Cassiodorus. With Special Advertence to the Technical Terminology of Administration. Hildesheim: Georg Olms Verlagsbuchhandlung, 1967. 


\title{
Kasnoantička Dalmacija i Panonija u Kasiodorovim Variae
}

\author{
Hrvoje Gračanin \\ Filozofski fakultet \\ Eberhard Karls Sveučilište u Tübingenu \\ Wilhelmstraße 36 \\ 72074 Tübingen \\ SR Njemačka \\ Odsjek za povijest \\ Filozofski fakultet \\ Sveučilište u Zagrebu \\ Ivana Lučića 3 \\ 10000 Zagreb \\ Republika Hrvatska \\ E-adresa: hrvoje.gracanin@gmail.com
}

\section{Sažetak}

Članak donosi historiografsku analizu Kasiodorovih Variae kao izvora za kasnoantičku povijest Dalmacije i Panonije, pokrajina kojima su Ostrogoti vladali četrdesetak godina, otprilike od sredine 490 -ih do sredine 530-ih godina. Povijesni podaci o Dalmaciji i Panoniji koji se mogu izlučiti iz odabranih pisama analiziraju se s obzirom na to što nude u vezi s političkim, upravnim, gospodarskim, društvenim i etničkim prilikama u obje pokrajine tijekom prva tri desetljeća šestog stoljeća koja se znatnim dijelom poklapaju s početkom Justinijanovog doba. Ondje gdje je prikladno ti se podaci sravnjuju s onim što se može doznati iz drugih dostupnih izvora, kako pisanih, tako i arheoloških. Na drugoj razini, analiza uključuje raščlambu narativnih elemenata, intelektualnih i političkih konteksta te ideoloških koncepcija i implikacija koje tvore i definiraju odabrana pisma kao i proizlaze iz njih. Variae mogu mnogo toga ponuditi i kao spremnica povijesnih podataka korisnih za utemeljeni uvid u život Panonije i Dalmacije pod ostrogotskom vladavinom u prvoj polovini šestoga stoljeća i kao literarno svjedočanstvo o tome kako se regija mogla doimati vanjskim promatračima. Pisma sadrže i elemente političke ideologije ostrogotskih kraljeva prenesene u lokalni kontekst, koji se mogu koristiti kako bi se definiralo mjestu koje su pokrajine zauzimale u posredovanju te ideologije. Pisma ukazuju da je pokrajinska uprava Dalmacije i Panonije tijekom ostrogotskog razdoblja bila složena i dobro diferencirana. Tvorili su je vojni i civilni dužnosnici s jasno razlučivim funkcijama. Kasnorimski pokrajinski sustav je uvelike bio zadržan, ali su uvedene i administrativne inova- 
cije, od kojih je najistaknutija stvaranje provincijske komitive koja je objedinila najvišu vojnu i civilnu vlast u pokrajini, što jasno ukazuje na militarizirani karakter ostrogotskog sustava vlasti. Osim comites provinciae, zasvjedočen je bar jedan lokalni comes Gothorum na, kako se čini, municipalnoj razini, vojni comes civitatis, i to vjerojatno Siscije. Daljnje promjene koje su uvele osttrogotske vlasti bilo je spajanje Savije i Dalmacije u jednu upravnu cjelinu pod istim provincijskim komesom, kao i stvaranje zasebne komitive za otoke Krk i Cres u Kvarnerskom zaljevu, koja je, kako se čini, imala civilni karakter, a nije bila vojnopomorska oblast kako se obično misli. Istovremeno, čini se da su Savija i Dalmacija zadržale vlastite samostalne nadležnosti i odvojene civilne rimske namjesnike sa sudskim i fiskalnim ovlastima nad rimskim stanovništvom. Rimski namjesnik možda je postojao i u Sirmijskoj Panoniji. Važno je napomenuti da se čini kako je pravilno administrativno ime pokrajine Savije u ostrogotskom razdoblju glasilo Suavia, zbog, kako se misli, znatne lokalne nazočnosti Sveva. Zahvaljujući Variae moguće je do određenog stupnja rekonstruirati i gospodarske prilike u Dalmaciji i Panoniji u šestom stoljeću. Problemu s utjerivanjem poreza u pokrajinama posvećeno je mnogo pozornosti, osobito u vezi sa Savijom i Dalmacijom, ali se na to ne smije gledati kao na bitno drugačiju situaciju nego u kasno rimsko doba. Međutim, uzimajući u obzir da je rimski pokrajinski sustav praktično prestao postojati u južnoj Panoniji u 430-im godinama, to pokazuje kako je proces ponovnog privikavanja lokalnog stanovništva na nekadašnje stanje bio spor i težak, te nailazio na otpor. Ovo svjedoči i o činjenici da je u pokrajinama ponovno uveden i održavan sofisticirani rimski sustav oporezivanja, što je bio izvanredan uspjeh. Osim toga, čini se da je Dalmacija doživjela stanovitu razinu blagostanja, jer se navodi obveza na porez na promet siliquaticum, što bi svakako upućivalo na razvijene komercijalne aktivnosti. Štoviše, ostrogotske su vlasti prikazane i kao naročito zainteresirane za oživljavanje pokrajinskog rudarstva, što je, čini se, imalo određenog uspjeha jer su arheološka istraživanja pružila dokaz da je bar jedno rudarsko postrojenje u današnjoj sjeverozapadnoj Bosni i Hercegovini bilo operativno pod istočnorimskom vladavinom koja je uslijedila. Pisma pružaju i dovoljno poučan uvid u temeljne strukture pokrajinskog društva u Dalmaciji i Panoniji, koje je zadržalo obilježja kasnorimskog društva, a pokazuju i da se održao municipalni sustav s defensores i curiales. Bilo je i novih skupina koje su zastupale kategorije označene kao capillati i barbari antiqui. Potonje je i etnokulturna oznaka, a smatra se kako se odnosi na svevske stanovnike Savije. I uz to, moguće je da je to bila opća oznaka za razne druge nerimske skupine koje su živjele u pokrajini, izuzevši Gote. Variae jasno potvrđuju prisutnost gotskog stanovništva u pokrajini, zacijelo uglavnom u pokrajinskim prijestolnicama. S obzirom na to da je obraćanje barbarima i Rimljanima naseljenima u Sirmijskoj Panoniji jedino takvo u Variae, može se smatrati naznakom da su nerimski stanovnici činili znatan dio ukupnog pokrajinskog stanovništva. S druge strane, čini se da Dalmacija nije imala velik broj nerimskog 
stanovništva, uključujući u to i Gote. Nadalje, ostrogotske vlasti su prikazane da aktivno utječu na etničku sliku preseljenjem i prihvaćanjem barbarskih skupina na ostrogotski teritorij. Čini se da je ovo područje imalo vidno mjesto u političkoj ideologiji istočnogotskih vlasti kao sporna oblast između Istočnog i Zapadnog Rimskog Carstva. Osim toga, Sirmijska Panonija je posebno istaknuta kao "bivše sjedište Gota," opaska koja možda odražava Teoderikov osjećaj posebne vezanosti za pokrajinu koja je u prošlosti već bila pod vlašću Gota, štoviše vjerojatno pod neposrednom kontrolom samog Teoderika. Slika pokrajina koja izvire iz Variae je dvojaka. $S$ jedne strane, pokrajine su prikazane da stoje pod pritiskom raznih problema. To posebno vrijedi za Saviju koja je predstavljena kao pod opsadom različitih vrsta nedjela, u kojima je naizgled udjela imala čitava pokrajinska društvena i upravna struktura. S druge strane, neminovno proizlazi i dojam o neprestanim pokušajima i brizi središnje vlasti da se osiguraju uređeni uvjeti života i poštovanje zakona, civilitas. U skladu s time moguće je pisma razumjeti i kao posredovanje jasne poruke da su južnopanonske i dalmatinske pokrajine, usprkos ponekad vrlo nepovoljnim okolnostima, bile sačuvane za romanitas zahvaljujući gotskoj kraljevskoj vlasti te sposobnim i pouzdanim dvorskim i državnih rimskim službenicima.

Ključne riječi: Kasiodorove Variae, Ostrogoti, Panonija, Dalmacija, šesto stoljeće 